\title{
Don't Go in the Water: On Pathological Jurisdiction Splitting
}

Jamison E. Colburn

Follow this and additional works at: https://elibrary.law.psu.edu/fac_works

Part of the Environmental Law Commons, and the Water Law Commons 


\title{
Don't Go in the Water: On Pathological Jurisdiction Splitting
}

\author{
Jamison E. Colburn ${ }^{*}$
}

"If there is any fact which may be supposed to be known by everybody, and, therefore, by courts, it is that swamps and stagnant waters are the cause of malarial and malignant fevers, and that the police power is never more legitimately exercised than in removing such nuisances."'

I. A SWAMP BY MADISONIAN DESIGN........................................ 4

II. CHOICES OF LAW: VerTiCAL, HORIZONTAL, OTHER ..................... 11

A. Federal Jurisdiction and Waters: Hybridizing Rules of

Decision

B. Erie's Shadow: McCarran, Abstention, and the Federal Forum

III. WATER RIGHTS TAKINGS: ClAIMS WITHOUT A FORUM?

A. Denominators and Dual Sovereignty in Constitutional

Property ..................................................................... 36

B. Tales from the Klamath: Water Rights as Property............... 39

IV. DEFINING "WATERS": A DELEGATION TO WHOM? ...................... 49

A. Judicial or Administrative Authority? ............................ 50

B. Judicial Choice: Facts, Fictions, and Article III ................. 57

V. PATHS FORWARD......................................................... 60

A. Righting Waters Adjudications ................................... 62

* Joseph H. Goldstein Faculty Scholar \& Professor of Law, Penn State University. For terrific advice and conversations on prior drafts, I thank Bob Adler, Amy Greenberg, John Leshy, Dave Owen, Jeff Pojanowski, Dan Tarlock, and Sandi Zellmer. For extraordinary help locating sources I thank Alison Ruckert and the Penn State Law Library.

1. Leovy v. United States, 177 U.S. 621, 636 (1899). 
B. Jurisdiction by Rule: Fixing the CWA ………..........................6 66

C. Righting Reclamation Interests ............................................. 67

\section{A SwAmp By MADISONIAN DESIGN}

Since Hobbes, the "central question of liberal political theory has been how, in a world marked by the legitimate and reasonable pursuit of self-interest, government can be sustained."2 Madison's iconic solution was to enlarge the "practicable sphere" of the state, ${ }^{3}$ scaling it up to enable factions to check each other, averting the tyranny they might inflict were they to dominate. ${ }^{4}$ But the "mutability" Madison saw in the laws of the original states also convinced him that stabilizing legal relations was key. ${ }^{5}$ And he expected these states and his new republic to check each other, ${ }^{6}$ seeing in their competition a novel and unique security to liberty. ${ }^{7}$ Finally, Madison had a hand in the grand compromise behind our federal judiciary. ${ }^{8}$ He championed the Convention's decision to let Con-

2. Da Vid Held, MOdels of Democracy 70 (3d ed. 2006).

3. See Lance Banning, The Practicable Sphere of a Republic: James Madison, the Constitutional Convention, and the Emergence of Revolutionary Federalism, in BEYOND CONFEDERATION: ORIGINS OF THE CONSTITUTION AND AMERICAN NATIONAL IDENTITY 162 (Richard Beeman et al. eds., 1987).

4. See The Federalist No. 10, at 64 (James Madison) (Jacob E. Cooke ed., 1961) ("Extend the sphere, and you take in a greater variety of parties and interests; you make it less probable that a majority of the whole will have a common motive to invade the rights of other citizens; or if such a common motive exists, it will be more difficult for all who fecl it to discover their own strength, and to act in unison with each other.").

5. See James Madison, Vices of the Political System of the United States, in JAMES MADISON: WRITINGS 69, 75 (Jack N. Rakove ed., 1999).

6. See THE FEDERALIST NO. 51, at 350-52; Banning, supra note 3, at 170.

7. See Peter S. Onuff, State Sovereignty and the Making of the Constitution, in Conceptual Change and the Constitution 78 (Terence Ball \& J.G.A. Pocock eds., 1988). On Madison's special influence in the horizontal and vertical structuring, as well as its earliest "liquidation" into the practical politics of the Federalist and Jeffersonian years, see LANCE BanNING, THE SACRed Fire of Liberty: James Madison and the Founding of the FedERAL RePUBlic (1995); DREW MCCOY, THE LAST OF THE FATHERS: JAMES MADISON (1986). On his cfforts in retirement to "spin" his own role and his evident disinterest in the judiciary, see MARY SARAH BILDER, MADISON'S HAND: REVISING THE CONSTITUTIONAL CONVENTION 117-18 (2015).

8. See Richard H. Fallon, Jr. et al., The federal Courts and the Federal System 4-19 (7th cd. 2015) (collecting research describing the Convention's debates and structuring of Article III and Madison's influence); Michael G. Collins, Article III Cases, State Court Duties, and the Madisonian Compromise, 1995 WISC. L. REv. 39, 58-68 (1995). The inferior tribunals Article I empowers Congress to "constitute," together with the lower courts Article III empowers it to "ordain and establish," have long tested the boundaries between distinct congressional authorities. See James E. Pfander, Article I Tribunals, Article III Courts, and the Judicial Power of the United States, 118 HARV. L. REV. 643, 646-71 (2004); RiCHARD A. POSNER, THE FEDERAL 
gress structure the judiciary and its relationship to state courts while framing Article III to elevate the appointment, tenure, and salary of its judges. ${ }^{9}$

This architecture, by splitting up the authority to make law, ${ }^{10}$ aimed to keep all but the strongest coalitions from changing federal law through Article I, $\S 7 .{ }^{11}$ But if Madison's legend has alternatively cast legal battles as prelude to compromise and substitute for violence, ${ }^{12}$ his vision has become a pathology to our waters as natural resources. As drought, depletion, wetland losses, toxic tides, and hypoxic dead zones all mount and sea-level rise accelerates, it grows increasingly evident that dangerous problems in and around the nation's waters are not being resolved. ${ }^{13}$ The party duopoly our Constitution entrenches bears little as reliably as it does gridlock and voter antipathy. ${ }^{14}$ By aligning private interests against fifty-two rival governments, it makes common cause increasingly uncommon. It gives few assurances of accurately distinguishing the local from the national ${ }^{15}$ or infringement from governance. ${ }^{16}$

COURTS: CHALLENGE AND REFORM 40-50 (2d ed. 1996); LAURENCE H. TRIBE, CONSTITUTIONAL CHOICES 47-65, 84-98 (1985).

9. See Julius Goebel, JR., 1 History of the Supreme Court of the United States: ANTECEDENTS AND BEGINNINGS TO 1801, at 245-48 (1971).

10. See SAMUEL H. BEER, TO MAKE A NATION: REDISCOVERY OF AMERICAN FEDERALISM (1993); JENNIFER NEDELSKY, PRIVATE PROPERTY AND THE LIMITS OF AMERICAN CONSTITUTIONALISM: THE MADISONIAN FRAMEWORK AND ITS LEGACY (1990); Larry H. Kramer, Understanding Federalism, 47 VAND. L. REV. 1485 (1994); Michael W. McConnell, Federalism: Evaluating the Founders' Design, 54 U. CHI. L. REV. 1484, 1492-1507 (1987); cf. JAMES M. BuChanAN \& GoRdon TUllock, The CALCulus of CONSENT: LoGiCAl Foundations OF CONSTITUTIONAL DEMOCRACY 17-30 (1962) (distinguishing normative theories of collective action from descriptive accounts).

11. See Robert A. DAhl, A Preface to Democratic Theory (1956) (calling Madison's account of the Constitution "institutionalist" and describing its fixation on inter-institutional checking); HELD, supra note 2, at 160-65; Bradford R. Clark, Separation of Powers as a Safeguard of Federalism, 79 TEX. L. REV. 1321 (2001); William N. Eskridge, Jr. \& John Ferejohn, The Article I, Section 7 Game, 80 GEO. L.J. 523 (1991).

12. See Greg Weiner, Madison's Metronome: The Constitution, Majority Rule, AND THE TEMPO OF AMERICAN POLITICS (2012). Madison was not without peers. But the record, as with his noted accounts of majoritarian tyranny, is uniquely developed in his case. See BILDER, supra note 7, at 6-7; DAHL, supra note 11, at 4-5.

13. See Rhett B. Larson, Water Security, 112 Nw. U. L. REV. 139, 164-80 (2017)

14. See Keith Krehbiel, Pivotal Politics: A Theory of U.S. Lawmaking 227-36 (1998); James A. Gardner, Madison's Hope: Virtue, Self-Interest, and the Design of Electoral Systems, 86 IOWA L. REV. 87, 89-90 (2000); Richard H. Pildes, Romanticizing Democracy, Political Fragmentation, and the Decline of American Government, 124 YALE L.J. 804 (2014); Richard H. Pildes, Why the Center Does Not Hold: The Causes of Hyperpolarized Democracy in America, 99 CAL. L. REV. 273 (2011).

15. See Larry D. Kramer, Putting the Politics Back into the Political Safeguards of Federalism, 100 COLUM. L. REV. 215 (2000) (arguing that party duopoly and discipline motivate Congress above all to respect state autonomy). "Inflexible divisions between what is national and what 
Indeed, unless we count indecision, indeterminacy, or disengagement as ends in themselves, we must confront the possibility that our jurisdiction-splitting tendencies are not fit for today's resource crises. ${ }^{17}$

Three jurisdictional jams make the case. The first is an old, familiar problem for many in the West. State law rights to appropriate water that compete with federal reserved rights to use the same waters have long opposed state to federal law and jurisdiction. ${ }^{18}$ Federal reservations-for Indian communities, national forests, parks, monuments, or other federal ends-impliedly retained whatever water uses were necessary to their ends. ${ }^{19}$ This body of federal common law should preempt inconsistent state law. ${ }^{20}$ Yet most water rights are adjudicated in state courts, leaving them the bulk of that job subject only to the Supreme Court's certiorari jurisdiction. ${ }^{21}$ But when a state court elaborates federal law, the authoritative force behind its declarations ebbs. ${ }^{22}$ Indeed, with reserved rights grounded in federal law, ${ }^{23}$ "reverse-Erie" problems now feature in the

is local ceased long ago to make sense, a product of profound cultural, economic, and technological changes. ... And, so, from Dred Scott to the Now Deal to National League of Cities, the Justices' rare efforts to impose their views of the proper limits of federal power have been controversial failures that accomplished little other than to damage the Court's reputation." Id. at 289.

16. See Steven Levitsky \& Daniel Ziblatt, how Democracies Die 118-75 (2018); NEDELSKY, supra note 10, at 240-76.

17. Part $V$ isolates causes and paths forward.

18. See, e.g., Lawrencc J. MacDonnell, General Stream Adjudications, the McCarran Amendment, and Reserved Water Rights, 15 WYO. L. REV. 313 (2015); Scott B. McElroy \& Jeff J. Davis, Revisiting Colorado River Water Conservation District v. United States-There Must be a Better Way, 27 ARIz. ST. L.J. 597 (1995); John E. Thorson et al., Dividing Western Waters: A Century of Adjudicating Rivers and Streams, Part II, 9 U. DENV. WATER L. REV. 299, 337-432 (2006); John E. Thorson et al., Dividing Western Waters: A Century of Adjudicating River and Streams, 8 U. DENV. WATER L. REV. 355, 442-61 (2005).

19. See Winters v. United States, 207 U.S. 564, 576-77 (1908). Once such a federal reserved right has been adjudicated, that judgment binds the United States and opcrates to preclude the further litigation of the same claim(s). See Nevada v. United States, 463 U.S. 110, 129-32 (1983).

20. See, e.g., Nevada, 463 U.S. at 116 n.1; United States v. New Mcxico, 438 U.S. 696, 70002 (1978); Cappaert v. United States, 426 U.S. 128, 138-41 (1976). Likc other federal common law, it rests in uneasy tension with the text of the Supremacy Clause - which mentions only federal "Laws... made" as superior in force to state law. See Henry Paul Monaghan, Supremacy Clause Textualism, 110 COLUM. L. Rev. 731, 758-61 (2010).

21. See Arizona v. San Carlos Apache Tribe of Ariz., 463 U.S. 545, 569 (1983) (providing state courts with jurisdiction to adjudicate Indian water rights held in trust by the United States).

22. See infra notes $185-91$ and accompanying text.

23. Cf. Cappaert, 426 U.S. at 138 ("Reservation of water rights is empowered by the Commerce Clause... which permits federal regulation of navigable streams, and the Property Clause ... which permits federal regulation of federal lands.") (citations omitted); United States v. City \& Cty. of Denver, 656 P.2d 1, 16 (Colo. 1982) (noting the state court's duty under the Supremacy Clause to apply federal law to the federal lands' reserved rights). 
state court judgments adjudicating these rights. ${ }^{24}$ Moreover, any court's jurisdiction to adjudicate the legal status of a thing depends on that jurisdiction's relationship to that thing. ${ }^{25}$ No judgment rendered in the absence of a sufficient relationship should be a binding judgment. ${ }^{26}$ And with many waters this sufficiency is open to considerable doubts. All of these questions at the federal/state jurisdictional interface now cloud many Western water rights and will do so more in the coming years.

A second jam derives in part from the first. When government interferes with a water right, claims of "takings" liability will arise. ${ }^{27}$ Challenges to changes in the law affecting water rights, however, can easily bounce between state and federal forums and rules of decision. If it is federal interference and the claimed loss exceeds $\$ 10,000$ in value, the claim presumptively belongs in the United States Court of Federal Claims (CFC) by specific jurisdictional statute-the Tucker Act. ${ }^{28}$ But few water rights are both vested and then denied by federal authority. ${ }^{29}$ Any state taking actionable by federal right must be "final" before a federal forum may take jurisdiction,,$^{30}$ a prerequisite that itself has grown

24. See Robert T. Anderson, Water Rights, Water Quality, and Regulatory Jurisdiction in Indian Country, 34 STAN. ENVTL. L.J. 195, 206-14 (2015). As Professor Clermont puts it, "[b]y reverse-Erie, federal law flows down to govern in state court. Under currently expressed vicws of the doctrine, however, it does so by uncertain means and to an uncertain extent." Kevin M. Clermont, Reverse-Eric, 82 NOTRE DAME L. REV. 1, 5 (2006).

25. See, e.g., Phillips Petro. Co.v. Shutts, 472 U.S. 797, 817-20 (1985); Shaffer v. Heitner, 433 U.S. 186, 207-11 (1977). "Territorial" jurisdiction is usually distinguished from subject matter jurisdiction and no attempt is made here to do otherwise.

26. See RESTATEMENT (2D) OF JUDGMENTS $\$ 6$ (1982) ("A state may exercise jurisdiction to determine interests in a thing if the relationship of the thing to the state is such that the exercise of jurisdiction is reasonable."). This is increasingly problematic in the context of waters. $C f$. id. at $\$ 6 \mathrm{cmt}$. a (noting challenges of determining whether an intangible thing is "present" within a jurisdiction allowing forum's adjudication of legal relations to the thing).

27. See Brian E. Gray, The Property Right in Water, 9 WEST-NW. J. ENVTL. L. 1, 2 (2002). Takings liability under federal law stems from the Fifth Amendment's clause forbidding "private property [from being] taken for public use, without just compensation." U.S. CONST. amend. V. Beginning in the twentieth century this guarantee was extended to the "taking" of property's use and economic value by regulation. See infra notes 243-50 and accompanying text.

28. See 28 U.S.C. $\S 1491$ (2008). The Court of Federal Claims is an Article I "tribunal" the judges of which serve 15 -year terms after presidential nomination and senatorial confirmation. Id. $\S \S 171-172$. Federal district courts have concurrent jurisdiction under the so-called "Little Tucker Act" to hear (non-contract) claims against the United States for amounts not exceeding $\$ 10,000$. Id. $\$ 1346$.

29. Federal courts construing state law confront a familiar list of troubles. See Bradford $\mathbf{R}$ Clark, Ascertaining the Laws of the Several States: Positivism and Judicial Federalism After Erie, 145 U. PA. L. REV. 1459 (1997). Certifying question(s) to the appropriate state court(s) is one solution, see, e.g., Klamath Irr. Dist. v. United States, 635 F.3d 505, 515-20 (Fed. Cir. 2011), although it can bc problematic as well. See infra notes 307-11 and accompanying text.

30. See Williamson Cty. Reg. Planning Comm'n v. Hamilton Bank, 473 U.S. 172, 196-97 (1985); see also Duquesne Light Co. v. Barasch, 488 U.S. 299, 306 (1989) (construing 28 U.S.C. 
deeply uncertain. ${ }^{31}$ A state supreme court's attempt to declare its common law of water rights, for example, once brought decades of acrimonious litigation before an ultimate conclusion that the claimants' case was premature. ${ }^{32}$ Astonishingly complex claims now regularly arise from the federal government's moves to reallocate the water it has developed throughout the West. ${ }^{33}$ Much of the actual water diverted today only became available because of these costly federal programs. ${ }^{34}$ But the private interest in most water is already elusive enough when uncomplicated by that overlay of federal law and jurisdiction. When these reclamation dimensions are added to the takings calculus, the jurisdictional issues can eclipse all others. ${ }^{35}$

Finally, there is the epitome of jurisdiction splitting. The Clean Water Act's (CWA) geographic scope is defined by CWA $\S 502(7)$ as the "waters of the United States." 36 The Supreme Court once noted in dicta that this could mean "virtually all surface water in the country." ${ }^{37}$ But its three attempts to resolve things ${ }^{38}$ have joined mountains of lower court opinions to deeply ambiguous effect. ${ }^{39}$ By 2007 , its jurisdictional muddle had become acutely problematic, ${ }^{40}$ a status quo that has now been traded between parties in power and shows no sign of abating. ${ }^{41}$ When the administering agencies-the Environmental Protection Agency (EPA) and Army Corps of Engineers-attempted a rulemaking fix in

$\S 1257$ jurisdiction over states' "[f]inal judgments or decrees" as mandatory barrier to Supreme Court review of state court proceedings).

31. See infra note 262 and accompanying text.

32. See Robinson v. Ariyoshi, 887 F.2d 215, 219 (9th Cir. 1989).

33. Part III(B) explains.

34. See Charles F. Wilkinson, Crossing THe NeXt Meridian: Land, Water, AND the FUTURE OF THE WEST (1992). Thus, what is called "project water" "would not exist but for the fact that it has been developed by the United States." Israel v. Morton, 549 F.2d 128, 132 (9th Cir. 1977). With state and federal law combining to provide contracted rights to project water as available, jurisdictional and preemption issucs have long dominated water claims in the affected resources. See Reed D. Benson, Whose Water Is It? Private Rights and Public Authority Over Reclamation Project Water, 16 VA. ENVTL. L.J. 363, 369-408 (1997).

35. See infra notes $312-34$ and accompanying text.

36. 33 U.S.C. $\S 1362(7)(2012)$.

37. See Int'1 Paper Co. v. Ouellette, 479 U.S. $481,486 \&$ n.6 (1987).

38. See Rapanos v. United States, 547 U.S. 715 (2006); Solid Waste Agency of N. Cook Cty. v. U.S. Army Corps of Eng'rs, 531 U.S. 159 (2001); United States v. Riverside Bayvicw Homes, Inc., 474 U.S. 121 (1985).

39. See Jamison E. Colburn, Governing the Gradient: Clarity and Discretion at the Water's Edge, 62 VILL. L. REV. 81, 87-93 (2017).

40. Part IV(A) explains.

41. See Colburn, Governing the Gradient, supra note 39, at 95-115. 
$2015,{ }^{42}$ their rule faced over a dozen court challenges, pulling the Supreme Court into a jurisdictional battle over challenges to the rulemaking. ${ }^{43}$ In Nat'l Ass'n of Mfrs. v. Dept. of Defense, ${ }^{44}$ it held that preenforcement challenges were not within the scope of the CWA's special jurisdiction provision, CWA $\S 509(\mathrm{~b})(1)^{45}$ and must be heard (if at all) in district court under $\S 1331$ and the Administrative Procedure Act (APA). ${ }^{46}$ Yet suits of the kind can resolve little about the validity of administrative rules. ${ }^{47}$ With a second Trump Administration rule now in progress, ${ }^{48}$ jurisdictional uncertainty will continue to plague the CWA, clouding its prescribed controls for the governance of jurisdictional waters. $^{49}$

These three concentrations of jurisdictional disorder advance a simple thesis: waters in our federal system - the divided sovereignty of 'We the People'-are becoming increasingly ungovernable due in good part to our obsession with dividing the authority to declare the law. This may be a "national neurosis," 50 but waters have aggravated it immensely. Waters exist along a gradient marked by ambulatory if not indeterminate

42. See Final Rulc-Clean Water Rulc: Definition of "Waters of the United States," 80 Fed. Reg. 37053, 37054 (June 29, 2015).

43. See Nat'l Ass'n of Mfrs. v. Dep't of Def., 138 S. Ct. 617, 627 (2018).

44. 138 S. Ct. 617 (2018).

45. 33 U.S.C. $\$ 1369$ (b)(1) (2012). The Clean Water Act (CWA), like the Clcan Air Act, makes special provision for challenging particular EPA actions implementing the statute. Unlike the Clean Air Act, howcver, the CWA's list of covered actions includes no catchall providing for jurisdiction in all cases of nationally significant actions and does not consolidate the covered actions in a single court. See Nat'l Ass'n Mfrs., 138 S. Ct. 617 (2018).

46. See Nat'l Ass'n Mfrs., 138 S. Ct. at 628-34. "If at all" because pre-enforcement revicw of rulemakings, especially where the rules are "interpretative," is subject to a list of "ripeness," finality, and other prudential barriers fashioned by the Court. See Steven J. Lindsay, Timing Judicial Review of Agency Interpretations in Chevron's Shadow, 127 YALE L.J. 2448, 2456-65 (2018) (discussing Whitman v. Am. Trucking Ass'ns, 531 U.S. 457 (2001), Bennett v. Spear, 520 U.S. 154 (1997), and FTC v. Standard Oil of Cal., 449 U.S. 232 (1980)).

47. See infra notes $470-76$ and accompanying text.

48. Two U.S. district courts vacated and issued national injunctions against the Trump Administration's attempt to suspend the Obama Administration rule in fall 2018. See Puget Soundkecper All. v. Whecler, No. C15-1342-JCC, 2018 WL 6169196 (W.D. Wash. Nov. 26, 2018); South Carolina Coastal Conservation League v. Pruitt, 318 F. Supp. 3d 959 (D.S.C. 2018). The Trump Administration's attempt at a substitute was proposed in February 2019. See Revised Definition of "Waters of the United States," 84 Fed. Reg. 4154 (proposed Feb. 14, 2019).

49. The 2015 rule remains in effect in 22 states, the District of Columbia, and U.S. Territories. See Revised Definition of "Waters of the United States," 84 Fed. Reg. at 4162 . In 28 states the 2015 rule remains preliminarily enjoined while two merits cases are heard. Id. at 4161-62 (describing injunctions in Texas v. EPA, No. 3:15-CV-00162, 2018 U.S. Dist. LEXIS 160443 (S.D. Tex. Sep. 12, 2018); North Dakota v. EPA, 127 F. Supp. 3d 1047 (D.N.D. 2015)).

50. See Edward L. Rubin \& Malcolm Feeley, Federalism: Some Notes on a National Neurosis, 41 U.C.L.A. L. REV. 903, 905-06 (1994) 
boundaries. They change rapidly in quantity, quality, and value, ${ }^{51} \mathrm{a}$ function of the planet's hydrologic cycles and of our growth. The basins making them cover hundreds and thousands of square miles. But because their values are so spatially and temporally varied (it once was a certainty that wetlands cause malaria), waters invite dispute without end. Indeed, the resource itself may engender suspicion by resisting possession of any real or normal sort. Thus, one party, place, or state's reach for water will almost surely threaten someone, somewhere else. Adaptation can dissipate these rivalries, but the resource itself invites conflict all the same.

Jurisdiction is the authority to decide and declare legal relationsthe rights, duties, privileges, powers, immunities, etc., of law. ${ }^{52}$ Judicial jurisdiction is conventionally divided along two axes, personal and subject matter, ${ }^{53}$ and is territorialized by contacts and interests. ${ }^{54}$ Each is divisible vertically and horizontally. But "Our Federalism"55 also divides what might be called jurisdiction to prescribe, ${ }^{56}$ making each of the foregoing divisions divisible. Thus, for example, fragments of jurisdiction were what Congress was thought to have delegated in the CWA, where EPA's "Administrator is authorized to prescribe such regulations as are necessary to carry out his functions under th[e Act]," ${ }^{57}$ while elsewhere announcing that "the authority of each State to allocate the quantities of water within its jurisdiction shall not be superseded, abro-

51. See, e.g., DAVID OWEN, Where the Water Goes: Life AND DEATH Along the COLORADO RIVER 226-59 (2017).

52. Cf. Scott Dodson, Jurisdiction and Its Effects, 105 GEO. L.J. 619, 627 (2017) (labelling this a "watcred down" definition of jurisdiction). Bentham first proposed a conception of distinct legal relations and discrete means of their decision and declaration. See H.L.A. HART, ESSAYS ON BENTHAM: STUdiES IN JURISPRUDENCE AND POLITICAL THEORY 190-93 (1982).

53. See Ruhrgas AG v. Marathon Oil Co., 526 U.S. 574, 583-88 (1999) (holding that federal courts are not bound to decide subject matter or personal jurisdictional issues in any sequence bccause neither is more fundamental than the other). "The character of the two jurisdictional bedrocks unquestionably differs. Subject-matter limitations on federal jurisdiction serve institutional interests. They keep the federal courts within the bounds the Constitution and Congress have prescribed. . . Personal jurisdiction, on the other hand, 'represents a restriction on judicial power ... as a mattcr of individual liberty." Id. at 583-84.

54. See Mary Twitchell, The Myth of General Jurisdiction, 101 HARV. L. REV. 610 (1988).

55. Younger v. Harris, 401 U.S. 37, 44 (1970).

56. For our purposes, "vertical" allocations of jurisdiction are some demarcation between state and federal competence where "horizontal" allocations demarcate peer jurisdictions' competences. See Joseph P. Bauer, The Erie Doctrine Revisited: How a Conflicts Perspective Can Aid the Analysis, 74 NOTRE DAME L. REV. 1235, 1236 (1999).

57. 33 U.S.C. § 1361(a). 
gated or otherwise impaired." 58 Finally, although there can be no federal "commandeering" of state jurisdiction to prescribe, ${ }^{59}$ state courts' duty to adjudicate federal law ${ }^{60}$ has entailed a wide range of problems for waters.

Part II introduces the adjudication of water disputes and how jurisdiction embeds competing state and federal interests in the law and any resulting judgments. Part III examines a particular type of water right and how its alleged taking became a jurisdictional muddle. Part IV tracks the syndrome into the CWA's delegated jurisdiction(s) to prescribe controls on the pollution of waters. Part $\mathrm{V}$ considers possibilities for reform.

\section{CHOICES OF LAW: VerTiCAL, HORIZONTAL, OTHER}

More than most, the field of water rights reveals courts' discretion to fashion their own jurisdiction and rules of decision. After almost a century of "reasonable" use riparianism's development in the eastern United States, ${ }^{61}$ western state judiciaries forged a novel kind of private interest in surface waters. ${ }^{62}$ Their appropriative rights rewarded whoever first put water diverted from a stream or river to a "beneficial" use with own-

58. 33 U.S.C. $\S 1251(\mathrm{~g})$; see also id. $\S 1251(\mathrm{~b})$ (declaring the "policy of the Congress to recognize, preserve, and protect the primary responsibilities and rights of States to prevent, reduce, and eliminate pollution").

59. See Murphy v. Nat'l Collegiate Athletic Ass'n, 138 S. Ct. 1461, 1475-76 (2018) (noting that the anti-commandccring principle "may sound arcane," but it, like the Supremacy Clause, is an essential element of our system of "dual sovereignty").

60. See Evan H. Caminker, State Sovereignty and Subordinacy: May Congress Commandeer State Officers to Implement Federal Law?, 95 CoLuM. L. REV. 1001, 1022-60 (1995) (observing that state judiciaries are regularly "commandecred" into the administration of federal law by having to adjudicate federal claims and apply federal law in their courts)

61. See, e.g., Stratton v. Mt. Hermon Boys' Sch., 103 N.E. 87, 87 (Mass. 1913) ("The common law rights and obligations of riparian owners upon streams are not open to doubt."). Sympathetically interpreted, English precedents requiring that a water's natural flow remain unimpeded were adapted into an Americanized "liability rule" restraining only those diversions and uses harming others precisely because the courts aimed to support the productive use of surface waters. See MORTON J. HORWITZ, THE TRANSFORMATION OF AMERICAN LAW, 1780-1860, 34-47 (1977); see, e.g., Stratton, 103 N.E. at 88-89 (adapting the common law rule forbidding transfers of withdrawn water out of the watershed to one forcing downstream riparians to first prove the harm done to them by the diversion). Such adaptations can set a special kind of jurisdictional trap, though, as Part III shows.

62. See Robert G. Dunbar, Forging New RightS in WESTERn Waters 59-98 (1983). It was not entirely novel. Eastern courts had heard and rejected first-in-time arguments for, in their view, a tendency toward monopoly "meant that 'the public, whose advantage is always to be regarded, would be deprived of the bencfit which always attends competition and rivalry." HoRwITZ, supra note 61, at 43 (quoting Palmer v. Mulligan, 3 Cai. R. 307, 314 (N.Y. Sup. Ct. 1805)). 
ership of the diversion, regardless of where the use occurred or who had to go without. ${ }^{63}$ This first-in-time rule broke from the doctrines that preceded it by vesting robust entitlements in what had seemed like an inherently public ${ }^{64}$ thing. ${ }^{65}$ But they have always been interests of an unusual sort.

First, "beneficial use" remains the basis, measure, and limit of these interests. ${ }^{66}$ Whatever water is not put to use is no part of an entitlement. ${ }^{67}$ Second, even a senior right-holder may not change use(s) so as to substantially harm others. ${ }^{68}$ Paired with the seniority system's conventions against waste ${ }^{69}$ and the robust forfeiture and abandonment laws most Western states maintain, ${ }^{70}$ this interest is therefore heavily quali-

63. See Atchison v. Pctcrson, 87 U.S. (20 Wall.) 507, 510-11 (1874) (Field, J.). A locus classicus of this ownership thcory of appropriation is Hutchins' Water Rights Laws in the Nineteen Western States. See Wells A. Hutchins, Water RIGHTS LAWS IN THE NINETEEN WESTERN STATES 147 (1971). The first-in-time appropriative right was calculated to attract settlers and investment and that it did-for irrigated agriculture, mining, and other low-margin forms of production. See DUNBAR, supra note 62, at 209-11; Lawrence J. MacDonnell, Prior Appropriation: A Reassessment, 18 U. DENV. WATER L. REV. 228, 242-78 (2015).

64. Compare Marks v. Whitney, 491 P.2d 374, 380 (Cal. 1971) ("The power of the state to control, regulate and utilize its navigable waterways and the lands lying beneath them, when acting within the terms of the [public] trust, is absolute . . except as limited by the paramount supervisory power of the federal government over navigable waters.") (citations omitted), with United States v. Gerlach Live Stock, Co., 339 U.S. 725, 744 (1950) ("As long ago as the Institutes of Justinian, running waters, like the air and the sea, were res communes-things common to all and property of none.").

65. See DUNBAR, supra note 62, 209-17; HorwITZ, supra note 61, at 105-06; MacDonnell, supra note 63 , at 242-67.

66. See, e.g., Wyo. Stat. Ann. $\$ 41-3-101$ (2014) ("Beneficial use shall be the basis, the measure and limit of the right to use water at all times."); Washington v. Oregon, 297 U.S. 517, 527-28 (1936); HUTCHINS, supra note 63, at 439 ("Several statutes declare the historic principle, thus expressed ... 'Beneficial use shall be the basis, the measure and the limit of the right to the use of water."').

67. Compare Empire Water \& Power Co. v. Cascade Town Co., 205 F. 123, 129 (8th Cir. 1913) (holding that an appropriation for scenic beauty alone was insufficient as a beneficial use), with Colo. River Water Conserv. Dist. v. Rocky Mtn. Power Co., 406 P.2d 798, 800-01 (Colo. 1965) (holding that water left in a river has not been appropriated for a beneficial use, regardless of the habitat values served thereby).

68. See Taiawagi Helton \& Rhett Larson, Reallocations, Transfers, and Changes, in WATERS AND WATER RIGHTS $\$ 14.04$ (c) (3d ed. 2017); George Gould, Water Rights Transfers and Third-Party Effects, 23 LAND \& WATER L. REV. 1, 5 (1988).

69. See MacDonnell, supra note 63, at 294 ("[S]tates have authority to enact laws regulating the manner in which water rights are used. To date, states have been remarkably unwilling to excrcise this authority."); Stcve J. Shupc, Waste in Western Water Law: A Blueprint for Change, 61 ORE. L. REV. 483, 491 (1982) (noting that the legal standard for eliminating fractions of an appropriation because of "waste" is the local customary usage for the beneficial use at issue).

70. See MacDonnell, supra note 63, at 300-02; Janet C. Neuman \& Keith Hirokawa, How Good Is an Old Water Right? The Application of Statutory Forfeiture Provisions to Pre-Code Water Rights, 4 U. DENV. WATER L. REV. 1 (2000). 
fied..$^{71}$ All of that has complicated appropriative rights' status as property. ${ }^{72}$ Indeed, with most streams and rivers throughout the West having long been over-appropriated, protection from loss or reallocation has become synonymous with water rights. ${ }^{73} \mathrm{~A}$ shows how allocations of federal and state jurisdiction have clouded those protections and blocked the entitlement delineation that might enable better private ordering. B explains the withdrawal of federal jurisdiction and the jurisdictional policies that have left these disputes stranded in state courts lacking the authority to adjudicate them fully.

\section{A. Federal Jurisdiction and Waters: Hybridizing Rules of Decision}

Federal supremacy means at least that state law rights to use waters must yield to contrary federal law, ${ }^{74}$ including federal common law. ${ }^{75}$ It was federal common law that first confirmed to the nonoriginal states their sovereign title to the beds, banks, and flowing waters of the navigable rivers, streams, and lakes, and all tidelands within their territo$\mathrm{ry}^{76}$ - to whatever extent not displaced by other federal law. ${ }^{77}$ Federal

71. Cf. HUTCHINS, supra note 63, at 443 n.30 "Although an interest in realty, the appropriative right is a right of use and is subject to loss as a result of nonuse. It thus differs from title to land.").

72. Unlike most types of property, appropriative rights have robust prohibitions on speculative accumulation. See Gregory Hobbs, Reviving the Public Ownership, Antispeculation, and Beneficial Use Moorings of Prior Appropriation Law, 84 U. COLO. L. REV. 97, 128-32 (2013).

73. See OWEN, supra note 51.

74. Compare Gibbons v. Ogden, 22 U.S. 1, 210-11 (1824) (vacating injunction to enforce state law navigation monopoly on grounds that it was Congress's authority to regulate interstate commerce), with United States v. Rio Grande Dam \& Irr. Co., 174 U.S. 690, 709-10 (1899) (holding that a state-created right to impound and appropriate so much of the Rio Grande as to impair its downstream navigability must necessarily yield to any federal common law right of riparianism or to the flow needed for navigation).

75. See, e.g., Clark, supra note 11, at 1452-57; Henry J. Friendly, In Praise of Eric-and of the New Federal Common Law, 39 N.Y.U. L. REV. 383 (1964); Alfred Hill, The Law-Making Power of the Federal Courts: Constitutional Preemption, 67 COLUM. L. REV. 1024 (1967).

76. See PPL Montana, LLC v. Montana, 565 U.S. 576, 589-93 (2012); Phillips Petro. Co. v. Mississippi, 484 U.S. 469, 476-84 (1988); Oregon ex rel. State Land Bd. v. Corvallis Sand \& Gravel Co., 429 U.S. 363, 374-76 (1988); Montana v. United States, 450 U.S. 544, 554-57 (1981); Shively v. Bowlby, 152 U.S. 1, 48-49 (1894); Barney v. Keokuk, 94 U.S. 324, 338 (1876). This "rule assumed federal constitutional significance under the equal-footing doctrine. In 1842 , the Court declared that for the 13 original States, the people of each State, based on principles of sovereignty, "hold the absolute right to all their navigable waters and soils under them, subject only to rights surrendered and powers granted by the Constitution to the Federal Government." PPL Montana, 565 U.S. at 590 (quoting Martin v. Waddell's Lessee, 16 U.S. (Pet.) 367, 410 (1842)).

77. See Montana v. United States, 450 U.S. 544, $550-57$ (1981); United States v. Oregon, 295 U.S. 1 (1935). This includes the federal "navigation servitude." See, e.g., United States v. Republic Steel Corp., 362 U.S. 482 (1960); United States v. Commodorc Park, 324 U.S. 386 (1945); United States v. Cress, 243 U.S. 316 (1917); United States v. Chandler-Dunbar Co., 229 U.S. 53 
statutes dating from 1866 declared homesteaders and other entries upon the public domain throughout the West would have to vest their water rights under state law. ${ }^{78}$ Yet, by contrast, federal reservations, i.e., land areas reserved in trust for the public or for an Indian tribe, came to include their own water rights under federal common law. ${ }^{79}$ (The federal interest in that water was apparently "brooding" about ${ }^{80}$ until finally declared in $1908 .^{81}$ ) Federal reserved rights have ever since been thought beyond state law's control, ${ }^{82}$ although a majority of the Supreme Court could obviously change that. ${ }^{83}$

At the epicenter here, thus, are some of our federalism's most intractable problems. Recall that the Judiciary Act of 1789 was for more than a century understood to authorize federal courts to declare "general" law in cases before them, contrary local law notwithstanding. ${ }^{84}$ Indeed, admiralty jurisdiction- the lower federal courts' principal grant of original jurisdiction in 1789-nominally still authorizes as much in "maritime" cases. ${ }^{85}$ But in Erie Railroad Co. v. Tompkins, ${ }^{86}$ the Supreme Court held

(1913); South Carolina v. Georgia, 93 U.S. (3 Otto) 4 (1876); Pennsylvania v. Wheeling \& Belmont Bridge Co., 54 U.S. (13 How.) 518 (1852); Gibbons v. Ogden, 22 U.S. (9 Whcat.) 1 (1824).

78. See Paul Wallace Gates, History of Public Land Law Development 635-98 (1968). Construing the Desert Land Act and General Mining Act in California Oregon Power Co. v. Beaver Portland Cement Co., 295 U.S. 142, 158 (1935), the Court held that the statutes had severed unappropriated waters on the public domain and left their appropriation to state law (subject to the federal interests in use of federally reserved lands and in navigation). Id. at 158-59. See also Andrus v. Charlestonc Stone Prods. Co., 436 U.S. 604, 614 (1978).

79. See Arizona v. California, 460 U.S. 605 (1983); United States v. New Mcxico, 438 U.S. 696 (1978); Cappaert v. United States, 426 U.S. 128 (1976); Federal Power Comm'n v. Oregon, 349 U.S. 435 (1955); Winters v. United States, 207 U.S. 564 (1908).

80. Cf. S. Pac. Co. v. Jensen, 244 U.S. 205, 222 (1917) (Holmes, J., dissenting) ("The common law is not a brooding omnipresence in the sky but the articulate voice of some sovereign or quasi-sovcreign that can be identified ....").

81. See Winters, 207 U.S. at 577-78.

82. See Winters, 207 U.S. at 576 . Henry Winters's claim against the United States and the Fort Belknap reservation was itself a claim that he and other upstream irrigators had long diverted to beneficial uses whatever water might otherwise have becn allocated to the reservation. See DANIEL MCCOOL, NATIVE WATERS: CONTEMPORARY INDIAN WATER SETTLEMENTS AND THE SECOND TREATY ERA 9-14 (2002). Two lower federal courts and the Supreme Court all rejected the claim. See Winters, 207 U.S. at 576-78.

83. See infra notes $196-97$ and accompanying text.

84. See HORWITZ, supra note 61, at 245-52; William A. Fletcher, General Common Law and Section 34 of the Judiciary Act of 1789: The Example of Marine Insurance, 97 HARV. L. REV. 1513, 1517-38 (1984); Stewart Jay, The Origins of Federal Common Law: Part II, 133 U. PA. L. REV. 1231, $1267-71$ (1985); Stewart Jay, The Origins of Federal Common Law: Part I, 133 U. PA. L. REV. 1003, 1034-38 (1985).

85. See FALLON ET AL., supra note 8, at 688-90; Bradford R. Clark, Federal Common Law: A Structural Reinterpretation, 144 U. PA. L. REV. 1245, 1332 (1996). The passage from the preErie theory of admiralty to its modern, fitful existence somewherc between an authorized and a redundant 'enclave' of federal common law took decades. See DAVID W. ROBERTSON, 
that federal courts lacked such authority and rather must look to local law unless it is preempted by the Constitution, federal statute, or court rule. ${ }^{87}$ The Erie Court's practical aims were to harmonize adjudications in state and federal forums, ${ }^{88}$ but its legal bases are debated still today. ${ }^{89}$ Eight decades on, indeed, Erie remains a sea of cross-currents and contradictions. ${ }^{90}$ What is the proper scope today of a federal common law of waters or reserved rights? ${ }^{91}$ Any answer will turn on archaic federal

ADMIRALTY AND FEDERALISM (1970). But admiralty jurisdiction remains the exemplar. The 1789 Act's vesting of exclusive original jurisdiction was only to the extent that such jurisdiction had been exereised by admiralty courts before the Constitution. Cf. The Moses Taylor, 71 U.S. (4 Wall.) 411 (1867) (limiting exclusivity of 1789 grant to in rem actions against a vessel or its cargo). The Court has occasionally adopted state law as federal maritime law. See, e.g., Yamaha Motor Corp. v. Calhoun, 516 U.S. 199 (1996).

86. 304 U.S. 64 (1938).

87. See Erie, 304 U.S. at 74-76; see also CHARLES ALAN WRIGHT \& MARY KAY KANE, LAW OF FEDERAL COURTS 387 (6th ed. 2002). But see Hill, supra note 75 , at 1073-81 (arguing the Constitution presumes a great deal of "judicial creativity" and that federal common law derives its preemptive force from the Supremacy Clause despite not appearing expressly therein); Louise Weinberg, Federal Common Law, 83 Nw. U. L. REV. 805, 805 (1989) ("[T] here are no fundamental constraints on the fashioning of federal rules of decision."). Federal common law's unique footing-preemptive where valid yet arguably narrower than both state common law or federal legislative authority-survived Erie, though not fully intact. See Martha A. Field, Sources of Law: The Scope of Federal Common Law, 99 HARV. L. REV. 881 (1986).

88. See WRIGHT \& KANE, supra note 87, at 379-82 (discussing Hanna v. Plumer, 380 U.S. 460 (1960), Guaranty Trust Co. v. York, 326 U.S. 99 (1945), and the twin "Erie doctrine" aims of discouraging forum shopping and avoiding incquitable administration of the laws); John Hart Ely, The Irrepressible Myth of Eric, 87 HARV. L. REV. 693, 714-15 \& n.125 (1974) (discussing Klaxon Co. v. Stentor Elec. Mfg. Co., 313 U.S. 487 (1941), and its holding that Erie required federal courts sitting in diversity to apply the forum state's choicc of law doctrines, as the "Erie doctrine"); Field, supra note 87, at 899-902.

89. See Kermit Roosevelt 1II, Choice of Law in Federal Courts: From Erie and Klaxon to CAFA and Shady Grove, 106 Nw. U. L. REV. 1, 8 (2012) ("There is a surprising amount of disagreement about Erie's constitutional source.").

90. See Ely, supra note 88, at 696 (comparing the Court's explanations of Erie over the years to "shadows on cave walls"); Roosevelt, supra note 89, at 2 ("Erie analysis is notorious for the puzzles it has produced."). See generally Craig Green, Repressing Eric's Myth, 96 CAL. L. REV. 595 (2008). Erie left federal courts to adopt state law into federal, to choose between states in horizontal choices of law, and to create enclaves of federal law protecting vital federal interests. See Paul J. Mishkin, The Variousness of "Federal Law": Competence and Discretion in the Choice of National and State Rules for Decision, 105 U. PA. L. REV. 797 (1957). Some even argue it left courts to decide whether and to what extent interpretive methods are binding. See Abbe Gluck, The Federal Common Law of Statutory Interpretation: Eric For the Age of Statutes, 54 WM. \& MARY L. REV. 753 (2013).

91. Even after Erie the Court repeatedly endorsed the spontaneous recognition of preemptive federal "intcrests." See, e.g., Semtek, Int'l, Inc. v. Lockheed Martin Corp., 531 U.S. 497, 508 (2001); Gasperini v. Ctr. for Humanities, Inc., 518 U.S. 415, $436-39$ (1996); Boyle v. United Techns. Corp., 487 U.S. 500 (1988); Clearfield Trust Co. v. United States, 318 U.S. 363 (1942). Thus, in a suit brought by the United States against a neighboring landowner pumping groundwater and thereby imperiling Devil's Hole National Monument, as to the United States' claim to any "unappropriated" water, the Court declared that "[f]ederal water rights are not dependent upon 
statutes, pre-Erie precedents, varying state law and constitutions, and more, ${ }^{92}$ often to dizzying effect. ${ }^{93}$

Original and appellate federal jurisdictions have long been incongruent in key respects. ${ }^{94}$ Section 25 of the 1789 Act originally vested appellate jurisdiction to reverse or modify (only certain) state court judgments exclusively in the Supreme Court. ${ }^{95}$ Lower federal courts borrowed their procedures-but only in actions at law and only until 1938 - from their states while at the same time hearing state law claims 'saved to suitors' by the 1789 Act's admiralty provisions. ${ }^{96}$ (Common law causes of action in equity and their relationship to Article III have been embroiled in debate from the beginning. ${ }^{97}$ ) And, of course, state courts' hearing of federal claims has yielded a continual stream of incorrigible issues. 98 All of this (and more) has brought to our "one supreme Court" continuing debate about the precise value of a federal forum and of federal supremacy ${ }^{99}$ - to say nothing of reconciling judgments in a

state law or state procedures," Cappacrt v. United States, 426 U.S. 128, 145 (1976), nor, presumably, on the forum state law's inchoate distinctions between surface and groundwater. See also Sanitary Dist. of Chicago v. United States, 266 U.S. 405, 425-26 (1925) (holding that the United States, in protection of its sovereign interests in the navigability of the Great Lakes, could restrain states and municipalities from directing too much flow out of the basin).

92. On federal common law's tangled ties to these other sources of law, see Anthony J. Bellia, Jr., State Courts and the Making of Federal Common Law, 153 U. PA. L. REV. 825 (2005); Clark, supra note 85; Clermont, supra note 24, at 5-20; Field, supra notc 87, at 883-88; Fletcher, supra note 84 , at 1517-27; Weinberg, supra note 87.

93. See, e.g., United States v. Alpine Land \& Rcs. Co., 697 F.2d 851, 858 (9th Cir. 1983), cert. denied, 464 U.S. 863 (1983) (holding that federal district court could scrve as appellate forum to review actions of Nevada's State Engineer in exercise of supplemental jurisdiction over action initiated by United States pursuant to 28 U.S.C. $\$ 1345$ ).

94. See Evan Caminker, Allocating the Judicial Power in a "Unified Judiciary", 78 TEX. L. REV. 1513, 1515 (2000). But see U.S. CONST. art. III, $\$ 2$, cl. 1 ("The judicial power shall extend to all Cases, in Law and Equity, arising under this Constitution, the Laws of the United States, and Treatics...."). Congress withheld general federal question jurisdiction from the lower federal courts until 1875. See FALLON ET AL., supra notc 8 , at 28.

95. See Exxon Mobil Corp. v. Saudi Basic Indus., 544 U.S. 280, 283 (2005).

96. The adoption of the federal rules in 1938 merged admiralty, law, and equity actions into one form of action. POSNER, supra note 8, at 47-50.

97. See Anthony J. Bellia, Jr., Article III and the Cause of Action, 89 IOWA L. REV. 777, 782-92 (2004); Kristin A. Collins, "A Considerable Surgical Operation": Article III, Equity, and Judge-Made Law in the Federal Courts, 60 DUKE L.J. 249 (2010).

98. See Henry F. Hart, Jr., The Relations Between State and Federal Law, 54 CoLUM. L. REV. 489, 508 (1954); Danicl J. Meltzer, State Court Forfeitures of Federal Rights, 99 HARV. L. REV. 1128,1182 (1986). The Court has occasionally held that state procedure must yield to a fedcral right. See, e.g., Felder v. Casey, 487 U.S. 131 (1988) (holding that exhaustion and notice requirements in state law could not "unnecessary" burden federal claims).

99. See U.S. CONST. art. III, § 1; Hart, supra note 98. 
system of so many alternative forums. ${ }^{100}$

While the Supreme Court's jurisdiction to manage these tensions has long been both evident and divisive, ${ }^{101}$ old debts are increasingly coming due. Interstate disputes have presented them in boldest relief. These controversies have ever been the bedrock case for some federal forum. ${ }^{102}$ According to a pair of early twentieth-century opinions, the Supreme Court's original jurisdiction for suits between two or more states over shared waters stems from 1789-at least where the states are asserting their sovereign interests. ${ }^{103}$ But the Court's federal common law

100. See Michigan v. Long, 463 U.S. 1032, 1037-44 (1983). See generally William Baude, The Judgment Power, 96 GEO. L.J. 1807 (2008); Michael Soliminc, Supreme Court Monitoring of State Courts in the Twenty-First Century, 35 IND. L. REv. 335 (2002); Catherine T. Struve, Direct and Collateral Federal Court Review of the Adequacy of State Procedural Rules, 103 COLUM. L. REV. 243 (2003). State law rights, of course, can draw federal protections as such. See, e.g., Stop the Bcach Renourishment, Inc. v. Fla. Dept. of Envtl. Prot., 560 U.S. 702, 713-14 (2010); Bush v. Gore, 531 U.S. 98, 111 (2000) (Rehnquist, C.J., concurring); Memphis Light, Gas \& Water Div. v. Kraft, 436 U.S. 1, 9-12 (1978); Ingraham v. Wright, 430 U.S. 651, 659-62 (1977). But state court judgments are gencrally not to be reviewed in any federal court save onc-leaving much to the Supreme Court's discretion. See ExxonMobil Corp. v. Saudi Basic Indus., 544 U.S. 280, 28488 (2005).

101. "The Supremacy Clause and the Appellate Jurisdiction Clause, taken together, offer 'good evidence' that the Supreme Court has hierarchical authority over state courts on matters of fedcral law." Tara Leigh Grove, The Structural Case for Vertical Maximalism, 95 CORNELL L. REV. 1, 35 (2009). Yet the structure and reach of the judicial power was more divisive than anything else throughout the framing, ratification, the Judiciary Act of 1789 , or since. See ALISON L. LACROIX, THE IDEOLOGICAL ORIGINS OF AMERICAN FEDERALISM 180-213 (2010).

102. Cf. THE FEDERAlist No. 80, at 534 (Alexander Hamilton) (calling the existence of a neutral forum to resolve state-statc conflicts "essential to the peace of the union"); GOEBEL, supra note 9 , at 182-95. The argument went beyond neutral forums, of course. Delaware, faltering in competition with the Port of Philadelphia, vocally supported an cnhanced role for Congress over maritime commerce. See Harold Hancock, Delaware Becomes the First State, in THE CONSTITUTION AND THE STATES: THE ROLE OF THE ORIGINAL THIRTEEN IN THE FRAMING AND Adoption of the Federal Constitution 21, 26 (Patrick T. Conley \& John Kaminski eds., 1988). And the sectional collision sparked by Jay's efforts to conclude the infamous Gardoqui treaty with Spain secking commercial privileges in return for foregoing navigation of the Mississippi consumed the Virginia ratification procecdings. See Lance Banning, Sectionalism and the General Good, in RATIFYING THE CONSTITUTION 261 (Michael Allen Gillespic \& Michael Lienesch eds., 1989).

103. See Kansas v. Colorado, 185 U.S. 125, 139-40 (1902) (noting sources of Court's jurisdiction and the necessity that the Court fashion unique rules of decision); Missouri v. Illinois, 180 U.S. 208, 240-42 (1900) (holding that bill for injunction of upstream pollution was in pursuit of state's sovereign interests and therefore within the Court's original jurisdiction). The Court continues to regard 28 U.S.C. $\$ 1251$ (a) as both jurisdictional grant and authority to prescribe (equitable) rules of decision for (some) interstate waters cases. See, e.g., Florida v. Georgia, $138 \mathrm{~S}$. Ct. 2502, 2513-14 (2018); Montana v. Wyoming, 563 U.S. 368, 377 n.5 (2011) (noting a "lack of clarity in this area of water law"); Colorado v. New Mexico, 467 U.S. 310, 317-24 (1984) (denying Colorado an appropriation of the Vermejo River despite three quarters of the watershed's location in Colorado on the basis of the Court's own equitable principles). 
makes this forum-selection pivot increasingly opaque. ${ }^{104}$ Which cases actually belong before the Court in its original jurisdiction has grown deeply uncertain. For example, are interstate aquifers subject to the jurisdiction? ${ }^{105}$ And who/what may intervene in such an action? ${ }^{106}$ A newly declared reserved right to groundwater, ${ }^{107}$ for another example, is but the outset of a long journey through innumerable controversies over its relationship to other waters and their allocation. ${ }^{108} \mathrm{~A}$ state's attempt to disclaim its sovereign interest in such waters, similarly, would necessarily touch federal common law's place in that state's law and courts. ${ }^{109}$

Whether the Supreme Court has original or appellate jurisdiction over any of these controversies turns on party alignments, timing, and the precise claims presented-which, in turn, falls to the Court's own shifting theories of the available rights and remedies. ${ }^{110}$ And while its

104. See Bellia, supra note 92, at 847-51, 886-901; Clermont, supra note 24, at 28-32; Abbe Gluck, Intersystemic Statutory Interpretation: Methodology as "Law" and the Erie Doctrine, 120 YALE L.J. 1898, 1960-68 (2011); Jay Tidmarsh \& Brian J. Murray, A Theory of Federal Common Law, 100 Nw. U. L. REV. 585, 607-09, 631-49 (2006).

105. Compare Hood ex rel. Mississippi v. City of Memphis, 570 F.3d 625 (5th Cir. 2009), cert. denied, 559 U.S. 904 (2010) (holding that Tenncssce was necessary and indispensable party and dismissing diversity action in tort against city allcging injurious groundwater pumping), with Florida v. Gcorgia, $138 \mathrm{~S}$. Ct. 2502 (2018) (holding that downstream state had the right to prove that equitable apportionment of river could redress its injury even without the United States' party to lawsuit despite its control of the majority of the flow in the river system).

106. See, e.g., South Carolina v. North Carolina, 558 U.S. 256, 264-74 (2010) (permitting intervention by two water users, a bi-state supply organization and an energy utility, in an action for equitable apportionment).

107. See Agua Caliente Band of Cahuilla Indians v. Coachella Valley Water Dist., 849 F.3d 1262, $1267-72$ (9th Cir. 2017).

108. See Burke W. Griggs, Interstate Water Litigation in the West: A Fifty-Year Retrospective, 20 U. DENV. WATER L. REV. 153 (2017). Federal jurisdiction over the journey remains concurrent with state court jurisdiction. See Agua Caliente, 849 F.3d at 1272-73; WRIGHT \& KANE, supra note 87 , at 417-18 ("A case 'arising under' federal common law is a federal question case, and is within the original jurisdiction of the federal courts as such.").

109. See Oregon v. Corvallis Sand \& Gravcl Co., 429 U.S. 363, 381-84 (1977) (holding that state law determines state dispositions after statchood); Arizona Ctr. for Law in the Public Interest, 837 P.2d 158, 164-173 (Ariz. Ct. App. 1991) (invalidating state statute disclaiming public trust law on the grounds it was contrary to the public trust doctrine as well as the state's constitution); cf. Borax Consol., Ltd. v. Los Angeles, 296 U.S. 10 (1935) (holding that federal law prevented a federal patent's conveyance of a state's public trust property prior to statehood).

110. Cf. Oregon, 429 U.S. at 381-82 (reversing fresh precedent and holding that state property law, not federal common law, governs post-statehood dispositions of submerged lands absent a pre-statchood federal grant). On the same day it announced Erie the Court held that a state law water right must yield to contrary requirements of an interstate compact. See Hinderlider v. La Plata River \& Cherry Creek Ditch Co., 304 U.S. 92, 110 (1938). The Court famously regarded Hinderlider as an affirmation of federal common law of interstate waters after Erie. See, e.g., Illinois v. City of Milwaukee, 406 U.S. 91, 105-07, 107 \& n.7 (1972). Yet Hinderlider's federal common law theory of jurisdiction was quickly mooted by the Court's holding that the construc- 
judgments bind the parties, ${ }^{111}$ whether and how the Court's "equitable discretion" binds Congress, the Executive Branch, and/or nonparties is becoming deeply uncertain. ${ }^{112}$

If the Court's finality as to all federal law regardless of dispute ${ }^{113}$ stems largely from the Supremacy Clause, ${ }^{114}$ the interminable struggles over that supremacy frame our jurisdictional jams. ${ }^{15}$ Admiralty jurisdiction's interface with state law is the more familiar exemplar. ${ }^{116}$ The fed-

tion of interstate compacts approved by Congress will, in most circumstances, present a federal question. See Delaware River Joint Toll Bridge Comm'n v. Colburn, 310 U.S. 419, 426-28 (1940).

111. See Hinderlider, 304 U.S. at 104-05; $c f$. South Carolina v. North Carolina, 558 U.S. 256, 258-60 (2010) (treating as binding prior precedents on the norms for allowing intervenors in original jurisdiction actions); Florida, $138 \mathrm{~S}$. Ct. at 2512-13 (noting the Court's equitable power to "regulate and mould the process" it employs (quoting Kentucky v. Dennison, 65 U.S. 66, 98 (1860)). Despite its own convention to the contrary, the Court decided in 1971 that 28 U.S.C. $\$ 1251$ does not vest exclusive original jurisdiction in the Court over all interstate waters cases. See Ohio v. Wyandotte Chem. Corp., 401 U.S. 493, 496-99 (1971). Still, the parens patriae standing distinguishing actions brought by states from private disputes has resisted rigorous formulation. See A. Dan Tarlock, The Law of Interstate Apportionment Revisited, Updated and Restated, 56 U. COLO. L. REV. 381, 390-94 (1988). Finally, the Court rarely misses a chance to urge Congress and the states to fashion compacts or statutory solutions for interstate waters disputes, see Kansas v. Colorado, 514 U.S. 673, 678 (1995), although the precmptive scope of any such compact or statute must remain a federal question. See Texas v. New Mcxico, 482 U.S. 124, 128 (1987); Hill v. State, 894 N.W.2d 208 (Neb. 2017).

112. Cf. Texas v. New Mexico, 462 U.S. 554, 568 (1983) ("Where Congress has ... exercised its constitutional power over waters, courts have no power to substitute their own notions of an 'equitable apportionment' for the apportionment chosen by Congress."'(quoting Arizona $v$. California, 373 U.S. 546, 565-66 (1963))); Charles J. Myers, The Colorado River, 19 STAN. L. REV. 1, 46 (1966) ("The only question for serious debate is whether a congressional apportionment that destroys vested water rights gives the user a fifth amendment claim for compensation" (citing United States v. Twin City Powcr Co., 350 U.S. 222, 224 (1956)).).

113. See FALLON ET AL., supra note 8, at 474-77; POSNER, supra note 8, at 262-63; WRIGHT \& KANE, supra note 87, at 105; Pfander, supra note 8, at 689-97.

114. Cf. Cooper v. Aaron, 358 U.S. 1, 18 (1958) ("[T]he interpretation of the Fourteenth Amendment enunciated by this Court ... is the supreme law of the land, and Article VI of the Constitution makes it of binding effect on the States 'any Thing in the Constitution or Laws of any State to the Contrary notwithstanding."' (quoting U.S. CONST. art. VI, § 2)).

115. For a powerful synthesis of the textual and historical debates surrounding the Supremacy Clause's meaning, see Monaghan, supra note 20 . Whatever consensus there was behind the Judiciary Act of 1789 (and there was some), see WILLIAM R. CASTO, OLIVER ELLSWORTH AND THE CREATION OF THE FEDERAL REPUBLIC 59-76 (1997); GOEBEL, supra note 9, at 458-503, nothing in Article 111 or the 1789 statutes defined the "final judgment or decree" from lower courts to which the Supreme Court's appellate jurisdiction was to attach. See Cox Broad. Corp. v. Cohn, 420 U.S. $469,472-75$ (1975).

116. See generally ROBERTSON, supra note 85 . "[I]t is important to note that a great part of the federal-state choice-of-laws tangle in maritime cases is intimately involved with the notion that the federal maritime law is in some sense a brooding omnipresence over the sea." Id. at 138; see also Emest A. Young, Preemption at Sea, 67 GEO. WASH. L. REV. 273 (1999). 
eral interest in a uniform maritime law ${ }^{117}$ has long accommodated state law rights and remedies not inconsistent therewith. ${ }^{118}$ But vexing secondary issues arise from such a nexus. ${ }^{119}$ Federal law may be needed simply because the rule cannot be a state's. ${ }^{120}$ From there, gap-filling can easily become chasm-filling. ${ }^{121}$ State law has often featured in interstate waters disputes by its adoption as federal law. ${ }^{122}$ But variance in those laws then poses hard choice of law questions. ${ }^{123}$ The structural interplay of equitable discretion, concurrent jurisdiction, and statutory change, thus, can keep the relationships at issue perpetually unsettled. ${ }^{124}$

117. See, e.g., Chelentis v. Luckenbach S.S. Co., 247 U.S. 372, 384-85 (1918) (holding that maritime law's remedies for injured seamen are exclusive, whether case is adjudicated in state or fedcral court); So. Pac. Co. v. Jensen, 244 U.S. 205, 215-16 (1917) (holding that the federal maritime law precmpted inconsistent state workers' compensation statute providing remedy for a longshoreman's death on docked vessel's gangway).

118. This means both the federal adjudication of state law claims, see, e.g, Askcw v. Amcr. Waterways Operators, Inc., 411 U.S. 325 (1973); Kossick v. United Fruit Co., 365 U.S. 731, 741 (1961), and the state adjudication of (most) federal maritime claims. See, e.g., Madruga v. Supcrior Court, 346 U.S. 556 (1954); Red Cross Line v. Atlantic Fruit Co., 264 U.S. 109 (1924).

119. If the "foundation of jurisdiction is physical powcr," McDonald v. Mabce, 243, U.S. 90, 91 (1917) (Holmes, J.), territorially constrained judgments respecting interstate waters embody their own kind of paradox. See infra notes 455-64 and accompanying text.

120. See State ex rel. Dyer v. Sims, 341 U.S. 22, 26-28 (1951) (holding that state law may not determinc validity of state's entrance into a compact govcrning the pollution of interstate waters).

121. The supposed filling of interstices has prompted troubling structural questions across all three types of law mentioned by the Supremacy Clause. Compare Clark, supra note 11, at 1328-72 (revicwing the Constitution's "encumbering" of federal law making, its 'political safeguards of federalism,' and the Supremacy Clause's effects as substantive restraints on federal law's elaboration by courts), with Gluck, supra notc 104, at 1968-96 (describing a polyphonic, "intersystemic" debate about state and fedcral methodologies in statutory interpretation). See also Griggs, supra note 108, at 161-90.

122. See, e.g., Washington v. Oregon, 297 U.S. 517, 525-26 (1936) (holding, on the basis of statc law to similar effect, that groundwater pumping is not contrary to appropriative rights in the basin under adjudication); Wyoming v. Colorado, 259 U.S. 419 (1922) (finding from the laws of the respective states, both of which adhered to forms of prior appropriation, that principles of firstin-time governed their claims to same river); New York v. New Jersey, 356 U.S. 296, 311-13 (1921) (holding that New Jerscy's pollution of New York Harbor was not actionable because, among other reasons, New York law had permitted the exact same pollution).

123. Jurisdiction and choicc-of-law have long been reciprocally influential. See Perry Dane, Vested Rights, Vestedness and Choice of Law, 96 YALE L.J. 1191 (1987). But the federal interest in interstate waters dispute resolution is necessarily distinct from any state interests therein. $C f$. Dyer, 341 U.S. at 29 ("Where the States themselves are before this Court for the determination of a controversy between them, neither can determine their rights inter sese, and this Court must pass upon every question essential to such a determination..." (quoting Kentucky v. Indiana, 281 U.S. 163, 176-77 (1930))); Hinderlider v. La Plata River \& Cherry Creek Ditch Co., 304 U.S. 92 , 103 (1938) (noting that Colorado decree vesting plaintiffs' water rights under Colorado law could have no preclusive effect on New Mexico's claims to interstate stream).

124. See Field, supra note 87 , at $915-27$ (exploring the possibility that Erie had no constitutional - only statutory-grounds and that federal common law can be made as broadly as Con- 
Of course, the Court's appellate jurisdiction over state court adjudications of federal (reserved) rights has proven problematic in its own right. ${ }^{125}$ Indeed, as the Court's minimalism and flexibility toward federal claims on waters have become so manifest, ${ }^{126}$ considerable attention has been drawn to the scope of state rules of decision, to various indirect invitations to state courts to declare federal law, ${ }^{127}$ and to the debatable legacy of the Court's overall patterning. ${ }^{28}$

State law appropriative rights may still be associated with rugged individualism under "frontier conditions" and the delineation of "legal rights by courts in the context of a specific dispute."129 But this is a fantasy. ${ }^{130}$ The general stream adjudication, now infamous for its inefficiency and interminability, ${ }^{131}$ is by its nature a territorial action. ${ }^{132}$ It arises in a local forum of record, ${ }^{133}$ reaching only those claims sited

gress can legislate). Such uncertainties can feed back on to the Congressional powers involved, as well. See, e.g., Romero v. Int'l Term. Operating Co., 358 U.S. 354, 372-80 (1959) (holding, 5-4, that 28 U.S.C. $\$ 1331$ 's extension of federal court jurisdiction to "civil actions" arising under "the Constitution, laws, or treaties of the United States" did not embrace claims for relief arising under maritime law); see infra notes 374-96 and accompanying text.

125. See infra notes 194-206 and accompanying text.

126. See Colorado v. Ncw Mexico, 459 U.S. 176, 183 (1982) ("Our aim is always to secure a just and equitable apportionment "without quibbling over formulas" (quoting New Jcrsey v. Ncw York, 283 U.S. 336, 343 (1931)).). See generally Justin Huber \& Sandra Zcllmer, The Shallows Where Federal Reserved Water Rights Founder: State Court Derogation of the Winters Doctrine, 16 U. DENV. WATER L. REV. 261 (2013). On the vertical structural problems inherent in this minimalism, sec Grove, supra note 101.

127. Cf. Bellia, supra note 92 , at 902-03. "[A] constitutional principle that a state court may make federal law on the basis of its views of what national policy should be is unsustainable under the Supremacy Clause." Id. at 902.

128. See Griggs, supra note 108, at 161-65; Jason A. Robison, Wyoming's Big Horn General Stream Adjudication, 15 WYO. L. REV. 243, 285-88 (2015). On the legacy of the Court's singlc most important interstate waters precedent, see Josh Patashnik, Arizona v. California and the Equitable Apportionment of Interstate Waterways, 56 ARIZ. L. REV. 1 (2014).

129. MacDonnell, supra note 63, at 237. The so-called "Wyoming System" of permitting withdrawals is the dominant approach today, although even these states have relicd on general stream adjudications and related exercises of judicial power. See id. at 308-09.

130. See Thorson et al., Dividing Western Waters II, supra note 18, at 317-24.

131. See, e.g., Joseph M. Fcller, The Adjudication That Ate Arizona Water Law, 49 ARIZ. L. REV. 405 (2007); A. Dan Tarlock, The Illusion of Finality in General Water Rights Adjudications, 25 IDAHO L. REV. 271 (1988).

132. After Erie and Hinderlider, whatever rights its judgments may vest are necessarily subordinate to the uniquely federal interest in resolving the competing claims of interested states. See Tobias Barrington Wolff, Choice of Law and Federal Jurisdictional Policy in the Federal Courts, 165 U. PA. L. REV. 1847, 1871-78 (2017).

133. Venue in any forum where property in issue is located, i.e., a "local action," has long been conventional. See, e.g., Shaffer v. Hcitner, 433 U.S. 186, 196 (1977); Mullane v. Cent. Hanover Bank \& Trust Co., 339 U.S. 306, $311-13$ (1950); Pennoyer v. Ncff, 95 U.S. 714, 723 (1878). See generally Geoffrey C. Hazard, Jr., A General Theory of State Court Jurisdiction, 1965 SUP. CT. REV. 241 (1965). It has also been indirectly jurisdictional by barring adjudication wherever 
within the forum state. ${ }^{134}$ The aim of the proceeding is to resolve the seniority, location, beneficial use(s), and timing of extant diversionsand to avoid having a federal court do so. ${ }^{135}$ They are often cast as a kind of quiet title action ${ }^{136}$ and, in that, as affording at least a modicum of repose at completion. ${ }^{137}$ But they are usually structured by special statute as they also require considerable administrative support. ${ }^{138}$ And the validity of any such judgment will inevitably turn on the reasonableness of the forum's exercise of jurisdiction. ${ }^{139}$

Beyond the reification of rights for their merely having been to court, ${ }^{140}$ though, basin adjudications have resolved little. This is in part because to be a local action at all they must ignore the nature of the res itself: continuous, dynamic, shared systems prone to change, abuse, and neglect, the shares of which evade possession - by legal fiction or otherwise. ${ }^{141}$ Disputes over entitlements of that kind, their measurement, and the resulting judgments have yielded a uniquely chaotic jurisdictional landscape, ${ }^{142}$ as Part B explains.

the property is not. See Twitchell, supra note 54, at 616-17, 617 \& n.28. Despite most aquifers', rivers', and their tributaries' interstate extents, however, only a small fraction of water rights adjudications have ever been explicitly cxtratcrritorial in scope. See infra note 452 and accompanying text.

134. See Thorson et al., Dividing Western Waters, supra note 18, at 359-60. This has meant for rough handling of interests like Winters rights, see Huber \& Zellmer, supra note 126, and for confusing treatments of tributaries and groundwater. See Thomas H. Pacheco, How Big Is Big? The Scope of Water Rights Suits Under the McCarran Amendment, 15 ECOL. L.Q. 627, 632-43 (1988).

135. See Tarlock, supra note 131, at 281-82; Thorson et al., Dividing Western Waters II, supra note 18, at 331-37.

136. See, e.g., State Dept. of Ecology v. Grimcs, 852 P.2d 1044, 1048 (Wash. 1993). Despite this characterization's repeated rejection by commentators and some courts, see Tarlock, supra note 131 , at 283 , "[t]he assumption that adjudication can create certainty out of inherent uncertainty" has remained widesprcad. Id. at 273 . In the few claims filed by the United States on behalf of tribes or other federal rescrvations, federal courts repeatedly characterized the suits as quiet title actions. See, e.g., United States v. Ahtanum Irr. Dist., 236 F.2d 321, 339 (9th Cir. 1954).

137. See Thorson ct al., Dividing Western Waters II, supra note 18, at 358-59.

138. See Thorson et al., Dividing Western Waters II, supra notc 18, at 337-432.

139. See RESTATEMENT (2D) JuDgmENTS $\$ 6$ (1982); Rush v. Savchuk, 444 U.S. 321 (1980); Hanson v. Denckla, 357 U.S. 235 (1958).

140. As the Supreme Court held in 1938, the appropriative right decreed in one state has no necessary force over users in downstream states. See Hinderlider v. La Plata River \& Cherry Creek Ditch Co., 304 U.S. 92, 103 (1938).

141. Put simply, the double aspect most associated with property, a discrete thing and an owner's right to exclude others from it, see JAMES PENNER, THE IDEA OF PROPERTY IN LAW 71 (1997), is missing from these adjudications.

142. See Michelle Bryan, At the End of the Day: Are the West's General Stream Adjudications Relevant to Modern Water Rights Administration?, 15 WYO. L. REV. 461 (2015); Lawrence J. MacDonncll, General Stream Adjudications, the McCarran Amendment, and Reserved Water Rights, 15 WYO. L. REV. 313 (2015). 


\section{B. Erie's Shadow: McCarran, Abstention, and the Federal Forum}

In 1952, Nevada Senator Patrick McCarran maneuvered a waiver of sovereign immunity into a Justice Department appropriations bill, immortalizing himself in this "McCarran Amendment."143 That rider permitted the United States to be joined "as a defendant in any suit . . for the adjudication of rights to the use of water of a river system or other source." 144 McCarran was motivated in largest part by the specter of tribal reserved rights. ${ }^{145}$ Yet only about a dozen state court adjudications of basins weighing federal reserved rights have been completed. ${ }^{146}$ Though just a fraction, ${ }^{147}$ they have shown basin proceedings unfit to the task. ${ }^{148}$ If anything, they have further clouded the related rights in both extent and legal force.

The Supreme Court construed the McCarran Amendment as more than an immunity waiver, finding in it a federal policy of deferring to parallel state proceedings. In Colorado River Water Conserv. District $v$. United States, ${ }^{149}$ and again in Arizona v. San Carlos Apache Tribe, ${ }^{150}$ majorities of the Court held that a federal trial forum was not necessary to the adjudication of water claims arising under federal law because any

143. See McElroy \& Davis, supra note 18, at 601-05 (discussing enactment of waiver, codified today at 43 U.S.C. $\S 666$ ). In its first encounter, the Court held that McCarran's waiver included only the "general" stream adjudication-not just any "suit" involving water rights. See Dugan v. Rank, 372 U.S. 609, 618-19 (1963). Focus soon shifted to the necessary generality of such an adjudication, see United States v. Dist. Court for the Cty. of Eagle, 401 U.S. 520, 524-25 (1971); United States v. Dist. Court Water Div. No. 5, 401 U.S. 527 (1971), and then to the waiver's deeper policy motivations. See infra notes $149-60$ and accompanying text.

144. United States v. Idaho, 508 U.S. 1, 3 (1993) (quoting 43 U.S.C. § 666).

145. See, e.g., MCCOOL, supra note 82; Robert T. Anderson, Indian Water Rights and the Federal Trust Responsibility, 46 NAT. REsourCES J. 399 (2006); David H. Getches, The Unsettling of the West: How Indians Got the Best Water Rights, $99 \mathrm{MICH}$. L. REV. 1473 (2001) (reviewing JOHN SHURTS, INDIAN RESERVED WATER RIGHTS (2000)); Steven J. Shupe, Water in Indian Country: From Paper Rights to a Managed Resource, 57 U. COLO. L. REV. 561 (1986).

146. Thorson et al., Dividing Western Waters II, supra note 18. For examplc, following United States v. District Court for Eagle County, 401 U.S. 520 (1971), and United States v. District Court in and for Water Division No. 5, 401 U.S. 527 (1971), the Supreme Court of Colorado adjudicated the reserved rights for seven national forests, three national monuments, Rocky Mountain National Park, and countless springs and wells on other public lands in the state. See United States v. City \& Cty. of Denver, 656 P.2d 1 (Colo. 1982).

147. Cf. Anderson, supra note 24, at 213-14 (finding that 27 tribal water rights settlements had been approved but that some 250 tribes in the contiguous United States have still-unquantified water rights).

148. See MCCOOL, supra note 82 , at 44-50; Anderson, supra note 24, at 209-13 ("[T]his climate of uncertainty in litigation outcomes can lead tribes and states to forge settlements that may be approved by Congress.").

149. 424 U.S. $800,812-18(1976)$.

150. 463 U.S. 545,564 (1983). 
federal interests at stake therein could be adequately protected by state courts and/or the Supreme Court's own certiorari jurisdiction. ${ }^{151}$ The Colorado River Court insisted that this form of federal court abstention should be rare.$^{152}$ But its factored analysis ${ }^{153}$ came to stand for a federal interest in avoiding "piecemeal litigation."154 This federal interest has remained a common refrain ever since. ${ }^{155}$

Colorado River began as an extension of Railroad Commission v. Pullman abstention. ${ }^{156}$ Both remain staples of federal courts teaching and scholarship ${ }^{157}$ because they underline the centrality of emergent state law and state interests to the mysteries of concurrent jurisdiction. ${ }^{158}$ But Colorado River has since joined what might be called the Erie canon: the separation of jurisdiction to prescribe and jurisdiction to adjudicate and the insistence that the former not be collapsed into the latter. ${ }^{159}$

151. See San Carlos Apache Tribe, 463 U.S. at 571 ("State courts, as much as federal courts, have a solemn obligation to follow federal law. Moreover, any state-court decision alleged to abridge Indian water rights protected by federal law can expect to reccive, if brought for review before this Court, a particularized and exacting scrutiny commensurate with the powerful federal interest in safeguarding those rights from state encroachment."); Colorado River, 424 U.S. at 819 20 (holding that "[o]nly the clcarest of justifications" warrant federal courts refusing to excrcise jurisdiction granted them but that abstention in favor of statc court was warranted in general stream adjudication).

152. See Colorado River, 424 U.S. at 813; see also Moses H. Conc Mcm. Hosp. v. Mcrcury Constr. Corp., 460 U.S. 1, 19-29 (1983).

153. The Colorado River Court, after tabulating three separate abstention doctrines, noted that, ordinarily, abstention can be warranted if: (1) a state court has custody of the property at issuc in an in rem action; (2) the federal forum was somehow inconvenient; (3) the desirability of avoiding piecemcal litigation; and (4) the order in which jurisdiction had been obtained in the concurrent forum(s). See Colorado River, 424 U.S. at 818-19.

154. Moses H. Cone, 460 U.S. at 19.

155. See Feller, supra note 131.

156. 312 U.S. 496 (1941). Pullman directed federal courts to stay their proceedings in deference to a parallel state proceeding if doing so allowed the state court to resolve state law issues that could obviate the need for federal adjudication. See Barry Friedman, A Revisionist Theory of Abstention, 88 MICH. L. REV. 530, 534-35 \& n.20 (1989). Abstention can also avoid a need to certify statc law issues to a state court and hold the federal action in abcyance awaiting an answer. See Martha A. Ficld, The Abstention Doctrine Today, 125 U. PA. L. REV. 590, 605-09 (1977).

157. Cf. FALLON ET AL., supra note 8, at 1178 (observing after excerpting the Colorado River opinions that, apart from two narrow exceptions, "the Court had approved federal deference to pending state procecdings in only a few instances before Colorado River."). Even thosc who accept that federal rights do not always necessitate-a federal trial forum have found Colorado River troublesome. Cf. Friedman, supra note 156, at 588 ("Perhaps the most intriguing puzzle ... arises in the context of the Supremc Court's decisions regarding so-called Colorado River abstention.").

158. Cf. Friedman, supra note 156, at $591-94$ (noting that Colorado River abstention is unique in the posture of two-forum cases with the United States as a party and Congress's implicit preference for state-court resolution of combined statc/federal law claims).

159. See Ely, supra note 88; Paul J. Mishkin, Some Further Last Words on Erie: The Thread, 87 HARV. L. REV. 1682 (1974); Roosevelt, supra note 89, at 3-15. An exhaustive study of 
And that has submerged it deep within old debates about the nature of law, lawmaking, and our federalism. ${ }^{160}$

As Justice Stevens' dissent argued in San Carlos, McCarran's rider was no more than an immunity waiver for a particular kind of suit-not a state forum mandate. ${ }^{161}$ Practically speaking, federal adjudication of reserved water rights need no more disrupt or duplicate concurrent state proceedings than any other declaratory judgment would. ${ }^{162}$ If anything, experience suggests that having federal claims resolved relatively quickly and separately could be a considerable practical help to water rights delineation. ${ }^{163}$ For when federal reserved rights are adjudicated, subordinate issues invariably arise, leaving the resolution of the law to a deciding forum that lacks the right to settle that law or to refer it to a better forum. ${ }^{164}$ And as other federal common law doctrines have shown in the

Pullman abstention two years before Colorado River cast it as an indirect response to latent state and Congressional hostility toward the Court's famous "exception" to the Eleventh Amendment's bar on suits challenging state action in Ex parte Young, 209 U.S. 123 (1908). See Martha A. Field, Abstention in Constitutional Cases: The Scope of the Pullman Abstention Doctrine, 122 U. PA. L. REV. 1071, 1074-76 (1974).

160. See FALLON ET AL., supra note 8, at 588-634; Ely, supra note 88, at 695. See generally Edward A. Purcell, Jr., Brandeis and the Progressive Constitution: Erie, the Judicial POWER, AND THE POLITICS OF THE FEDERAL COURTS IN TWENTIETh-Century AMERICA (2000).

161. See San Carlos Apache, 463 U.S. at 573 (Stevens, J., dissenting).

162. See San Carlos Apache, 463 U.S. at 572-81 (Stevens, J., dissenting). As Professor Abrams argued shortly after Colorado River, any subsequent litigation in state court would be bound to give preclusive effect to any federal judgment by the Full Faith and Credit Clause, U.S. CONST. art. VI, much as any federal court litigation would be bound by the full faith and credit statute, 28 U.S.C. \$ 1738. See Robert H. Abrams, Reserved Water Rights, Indian Rights and the Narrowing Scope of Federal Jurisdiction: The Colorado River Decision, 30 STAN. L. REV. 1111 , 1125 \& n.91 (1978). Ultimately, "[f]ederal law is enforceable in state courts not because Congress has determined that federal courts would otherwise be burdened or that state courts might provide a more convenient forum - although both might well be true-but because the Constitution and laws passed pursuant to it are as much laws in the States as laws passed by the state legislature." Howlett v. Rose, 496 U.S. 356, 367 (1990).

163. See Thorson et al., Dividing Western Waters II, supra notc 18, at 437 ("Of the proceedings reviewed for this article, only Texas may have completed a comprehensive adjudication. The Texas adjudicators, however, did not have to face the complexity of federal reserved water rights claims or groundwater."); see also A. DAN TARLOCK ET AL., WATER RESOURCE MANAGEMENT: A CASEBOOK IN LAW AND PUBLIC POLICY 898-902 (3d ed. 2002).

164. In Colorado, for example, the state supreme court had to resolve as a matter of first impression whether federal reservations of springs and water holes necessarily reserved the "cntire yield" thereof, see City \& Cty. of Denver, 656 P.2d at 32-33 (holding they did not), whether "hot" springs were encompassed within the Pickett Act's or other federal statutes' reservations, id. at 33-34 (holding they were not), and whether the United States must follow Colorado procedures if it chooses to change points of diversion or future uses. See id. at 35 (holding that it must). See also In re Yakima River Drainagc Basin, 296 P.3d 835, 848-50 (Wash. 2013) (holding that prior federal court consent decree of 1964 was an adjudication and final judgment of certain other users claims cven without quantifying reserved rights); Conf'd Salish \& Kootenai Tribes v. Clinch, 158 
diversity jurisdiction, choices of forum and of law present ample discretion to federal courts guided by Erie's policy aims. ${ }^{165}$

The federal interest in avoiding piecemeal adjudication of mostly state law rights ${ }^{166}$ may have squared with the ambitions behind basin adjudications. ${ }^{167}$ Several states responded to Colorado River by enlarging their stream proceedings into what the Court had signaled that McCarran expected. ${ }^{168}$ But the cases soon grew so daunting that tribes and many private claimants simply took to settling their differences out of court. ${ }^{169}$ As Professor Tarlock observed decades ago, as modes of dispute resolution stream adjudications were barely fit to a distant past and completely unfit for the hand-to-hand combat water law and litigation became. ${ }^{170}$ Today, this is a pattern: if judicial proceedings can be avoided, most users do so. ${ }^{171}$

The adjudication of the Big Horn River system and the rights reserved to Wyoming's Wind River Indian reservation remain the cautionary tale. ${ }^{172}$ Quantification of the tribal rights reserved in the landmark

P.3d 377, 389 (Mont. 2007) (holding that tribes' still-unquantified reserved water rights do not preempt state's processing of a change of use application on river system); In re Snake River Basin Water System, 764 P.2d 78, 83-86 (Idaho 1988) (holding that McCarran Amendment's terms apply to basin-wide adjudications, including tributarics); Unitcd Statcs v. Bell, 724 P.2d 631, 63740 (Colo. 1986) (holding that application to amend rescrved rights did not relate back to original application); Statc ex rel. Greelcy v. Conf'd. Salish and Kootenai Tribes, 712 P.2d 754, 763-66 (Mont. 1985) (holding that tribe's irrigation priority date could be later than the "time immemorial" priority of tribe's in-stream flow claims supporting hunting and fishing rights).

165. See David L. Shapiro, Jurisdiction and Discretion, 60 N.Y.U. L. REV. 543, 566-70 (1985); Wolff, supra notc 132, at 1860-82.

166. Cf. Moses H. Cone Mem. Hosp. v. Mercury Costr. Corp., 460 U.S. 1, 16 (observing that the decision to abstain "docs not rest on a mechanical checklist, but on a careful balancing of the important factors as they apply" and that, although the "weight to be given to any one factor may vary greatly from case," "[b]y far the most important factor" is the "clear federal policy... [of] avoidance of piecemeal adjudication of water rights in a river system").

167. See McElroy \& Davis, supra note 18, at 606-12 (dcscribing Colorado's 1969 statutory reform of its water adjudication system, the United States' obstructionism in a series of Colorado cases, and Justice Brennan's majority opinion in Colorado River, "without any citation," invoking the McCarran Amendment's policy of deference even to proceedings like Colorado's month-tomonth adjudications).

168. See MacDonnell, supra note 63, at 309 ("States have initiated general adjudications primarily to force the federal government and Indian tribes to adjudicate their reserved water rights claims."); Pacheco, supra note 134, at 635-43.

169. See MCCOOL, supra note 82, at 48; Anderson, supra note 24, at 213; Feller, supra note 131, at 429-33; McElroy \& Davis, supra note 18, at 620-23.

170. See Tarlock, supra note 131 , at 284 ; see also Feller, supra note 131

171. See Bryan, supra note 142, at 509-11; Thorson et al., Dividing Western Waters II, supra note 18 , at $452-63$.

172. See Robison, supra note 128 , at 309-12. 
treaties of Fort Bridger quickly overshadowed other issues. ${ }^{173}$ The federal common law tracing to Winters required the courts to interpret the treaties' purposes. ${ }^{174}$ But that common law was skeletal. ${ }^{175}$ In fact, for modes of quantification there was exactly one governing precedent: the Supreme Court's decision adopting a special master's solution in Arizona v. California. ${ }^{176}$ There, the Court held that the Colorado River tribes' reserved rights should be quantified by reference to the irrigation they could practicably undertake on their reservations. ${ }^{177}$ This "practicably irrigable acreage" (PIA) standard came to animate the Wyoming proceedings, much to the appropriators' chagrin. ${ }^{178}$ Yet the Wyoming courts' elaboration of that standard raised more questions than it an-

173. See Anderson, supra note 24 , at $209 \& \mathrm{nn} .63-64$. The litigation was commenced in 1977 and came to include more than 20,000 claims-only the first two phases of which pertained to the tribes' claims stemming from treaties in 1866 and 1868. See In re Big Horn River System, 899 P.2d 848, 850 (Wyo. 1995) (Big Horn III). The basin adjudication was settled in 2014.

174. Cf. Washington v. Wash. State Comm. Passenger Fishing Vesscl Ass'n, 443 U.S. 658 , 675 (1979) ("[I]t is the intention of the parties, and not solely that of the supcrior side, that must control any attempt to interpret the treaties. When Indians are involved, this Court has long given special meaning to this rulc."); United States v. New Mexico, 438 U.S. 696, 700 \& n.4 (1978) (noting that the Court's applications of the Winters doctrine were the sources of authority for quantifying a national forest's reserved water rights).

175. In the Ninth Circuit, for example, most tribal rights "necessarily carry a priority date of time immemorial." United States v. Adair, 723 F.2d 1394, 1414 (9th Cir. 1983); see also Colville Confederated Tribes v. Walton, 647 F.2d 42, 47 (9th Cir. 1980); United States v. Ahtanum Irr. Dist. 236 F.2d 321, 326 (9th Cir. 1956); Skeem v. United States, 273 F. 93, 95 (9th Cir. 1921). The Washington Supreme Court agreed in In re Yakima River Drainage Basin, 296 P.3d 835, 840 (Wash. 2013). In In re Big Horn River System, 753 P.2d 76 (Wyo. 1988) (Big Horn II), the Wyoming Supreme Court purported to follow Adair and Walton while ignoring their true holdings, fixing the priority date as that of the later Fort Bridger treaty based solely on the United States' purposes. See id. at 112 .

176. 373 U.S. 546 (1963). Tellingly, that court was called upon to interpret federal statutes authorizing the major storage projects on the lower Colorado (the Boulder Canyon Act among them) and the alleged statutory allocations to the lower-basin states. See id. at 564-66. Within that task, the quantification of the five mainstem tribes' reserved water rights further embedded the litigants (and Special Master Rifkind) in a struggle to find a fair, workable standard. Id. at 59960 l. The Arizona Court adopted Ritkind's test, id., arguably making it federal common law. See Arizona v. California, 460 U.S. 605, 609-10 (1983).

177. See 373 U.S. at 601 ("How many Indians there will be and what their future necds will be can only be guessed. We have concluded, as did the Master, that the only feasible and fair way by which rescrved water for the reservations can be mcasured is irrigable acreage."). When the Supreme Court was later invited to "balance" Indian needs for water against other claimants" needs it refused to do so, citing the PIA standard as a bar to equitable interest balancing. See Arizona v. California, 460 U.S. 605, 616 (1983).

178. See Pctition for a Writ of Certiorari to the Supreme Court of Wyoming, Wyoming v. United States, 1988 WL 1094117 (Aug. 19, 1988), at 24 (arguing that the Wyoming Supreme Court's award using the PlA standard constituted a "windfall" to the tribes lacking "any evidence showing that the ... water was essential to meet the minimum needs of the Reservation or to accomplish its agricultural purpose") [hercinafter Wyoming Cert. Petition]. 
swered. A certiorari petition followed ${ }^{179}$ from which a monument to jurisdictional muddles emerged. ${ }^{180}$

The history of publicly financed irrigation works of dubious value, let alone those undertaken for nomadic peoples whose purposes had so diverged from the United States', has rarely appeared in the general stream adjudications. ${ }^{181}$ That history tied Wind River irrigation over the preceding century to what might still be irrigated in a future with committed federal support. ${ }^{182}$ It highlighted both the tribes' long-standing predicament (a lack of economic opportunity in central Wyoming ${ }^{183}$ ) and the PIA standard's anachronistic focus on a development strategy that had failed most places it had been tried. ${ }^{184}$ Yet the Wyoming courts

179. See Wyoming v. United States, 488 U.S. 1040 (1989) (granting petition in part). An equally divided court affirmed the Wyoming Supreme Court in Wyoming v. United States, 492 U.S. 406 (1989).

180. See Big Horn III, 835 P.3d at 275-78; see also Andrew C. Mergen \& Sylvia F. Liu, $A$ Misplaced Sensitivity: The Draft Opinions in Wyoming v. United States, 68 U. COLO. L. REV. 683 (1997).

181. See MCCOOL, supra note 82; Sylvia F. Liu, American Indian Reserved Water Rights: The Federal Obligation to Protect Tribal Water Resources and Tribal Autonomy, 25 ENVTL. L. 425, 434-37, 442-52 (1995); Mergen \& Liu, supra note 180, at 698-702. But cf. United States v. Shoshone Tribe of Indians, 304 U.S. 111, 111-15 (1938) (describing the history of settlemcnt, forcible resettlement of Arapahoc tribes, cessions, and economic distress on the reservation in litigation surrounding just compensation to tribes for land taken by United States). In Big Horn II, the Wyoming Supreme Court referred to this history as one of the tribes' "economic misfortunes," none of which were attributed to Whitc settlers or to the United States. See In re Big Horn River System, 753 P.2d 76, 84 (Big Horn II).

182. See MCCOOL, supra note 82, at 19-23. After holding that the Ft. Bridger treatics' sole purpose was to convert the tribes to a pastoral existence, the Wyoming Supreme Court concluded in Big Horn II that groundwater formed no part of their rescrved rights. See Big Horn II, 753 P.2d at 99-100. The court cited only the opinion of a district court sitting in diversity which had held that past "need and use" were the touchstones of reserved rights-not Congressional or tribal purposes. See id. at 99 (discussing Tweedy v. Texas Co., 286 F. Supp. 383 (D. Mont. 1968)).

183. See Mergen \& Liu, supra note 180, at 716-20 (showing the tension betwcen any arguments against tribal surpluses and the tribes' long-term best interests). As has long been noted of the PIA standard, tribal economic opportunities and autonomy are hardly advanced in most cases by rights to irrigation water. See, e.g., Martha C. Franks, The Uses of the Practicably Irrigable Acreage Standard in the Quantification of Reserved Water Rights, 31 NAT. RES. J. 549, 562-83 (1991).

184. The state's argument to the Supreme Court was that the Indians had made so little use of the diversions constructed throughout the twenticth century that a decree should include no further allocation. See Wyoming Petition, supra note 178, at 18-26; cf. Franks, supra note 183, at 583 ("A PIA court is asked to make an all-or-nothing decision on the feasibility of irrigation projects. Generally, it is not possible to justify the feasibility of some portion of a project.... Thus, either the whole project is fcasible or it is not."); David M. Stanton, Note-Is There a Reserved Water Right for Wildlife on the Wind River Indian Reservation? A Critical Analysis of the Big Horn River General Adjudication, 35 S.D.L. REv. 326, 335-40 (1990) (critiquing the Special Mastcr's Report and the Big Horn II opinion for ignoring extrinsic evidence and the texts of the treaties suggesting a reservation of in-stream flows for fish and wildlife was among the parties' purposes). 
seemed predisposed to reject what the tribes and many others already knew: water for instream flows protecting the ecosystem can be more valuable than more irrigation. ${ }^{185}$ They denied the tribes a right to groundwater. ${ }^{186}$ Seemingly unable to update federal common law, ${ }^{187}$ the Wyoming courts simply ignored the argument that the Fort Bridger treaties' broader purposes, i.e., to establish a "permanent home," 188 to "provide a homeland," 189 or help to create a "pastoral and civilized people," 190 urged the consideration of new uses. ${ }^{191}$

A fair question is whether original jurisdiction in a federal forum would have changed that. ${ }^{192}$ Most observers contend that neutral federal

185. See MCCOOL, supra note 82 , at 149-51; Franks, supra note 183 , at 563-83. Compare Bighorn II, 753 P.2d at 98-99 (denying four of five proposed uses because of treaty's supposed "sole agricultural purpose"), with In re Bighorn River System, 803 P.2d 61, 70 (Wyo. 1990) (Bighorn III) (holding that both Indians and successors-in-interest to Indian allotment purchasers alike should have their rights quantified by irrigable acreage standard). On the monetizable ccosystem services of a river like the Big Horn, see J.B. RUHL ET AL., THE LAW AND POLICY OF ECOSYSTEM SERVICES 205-12 (2007).

186. See Big Horn 11,753 P.2d at 99-100.

187. Inferior courts have often narrowed or updated Supreme Court precedents in other contexts. See Richard M. Rc, Narrowing Supreme Court Precedent from Below, 104 GEO. L.J. 921 (2016). The Arizona Supreme Court, for example, held that Arizona had not established the PIA standard as the sole, uniquely correct means of quantifying reserved rights. See In re Gila River System and Source, 35 P.3d 68, 77-78 (Ariz. 2001). The Supreme Court itself can do it more efficiently. See Richard M. Re, Narrowing Precedent in the Supreme Court, 114 COLUM. L. REV. 1861 (2014).

188. Agua Caliente Band of Cahuilla Indians v. Coachella Valley Water Dist., 849 F.3d 1262, 1270 (9th Cir. 2017) ("[W]hile we are unable to find controlling federal appellate authority explicitly holding that the Winters doctrine applies to groundwater, we now cxpressly hold that it does.").

189. Colville Confederated Tribes v. Walton, 647 F.2d 42, 47 (9th Cir. 1981) ("We are mindful that the reservation was created for the Indians, not for the benefit of the government. . . We also consider their need to maintain themselves under changed circumstances.").

190. Winters v. United States, 207 U.S. 564, 575 (1908).

191. Cf. Big Horn II, 753 P.2d at 96 (noting a lack of authority for using the "specific purpose test" to limit Indian reserved water rights to a "sole agricultural purpose," that the Special Master's interpretation was not a finding of fact while affirming the application of the PIA standard and nothing more). The state still argued that the Big Horn $I$ court had "granted a reserved water right $72 \%$ greater than the water needed by the Tribes after eighty years of extensive irrigation development ...."Wyoming Petition, supra note 178, at 25-26.

192. Commentary at the time took exception with the Wyoming courts' understanding of the treaties' purposes. See Franks, supra note 183, at 563-67; Mergen \& Liu, supra note 180, at 702 \& n.133; Stanton, supra note 184. Interpreting Winters's purposes standard had already been contentious, though. See, e.g., United States v. New Mcxico, 438 U.S. 696, 718-19 (1978) (Powcll, J., joined by Brennan, White, Marshall, dissenting) (rejecting the majority's narrowing construction of Gila National Forest's establishment purposes). Nevertheless, the Big Horn opinions cut a stark contrast with the federal courts' interpretation of the Klamath Indian tribes' treaty purposes. See United States v. Adair, 723 F.2d 1394, 1397-1400 (9th Cir. 1984). 
forums exist for precisely this type of case. ${ }^{193}$ And in the only certiorari grant involving a basin adjudication of Winters rights since Colorado River or San Carlos, the U.S. Supreme Court came to the brink of vacating the Wyoming decision. ${ }^{194}$ The Wyoming courts had combined historically irrigated acres with acres "susceptible to sustained irrigation at reasonable costs," "195 a move a majority of the Supreme Court concluded had been insufficiently sensitive to non-Indian users in the basin. ${ }^{196}$ Justice O'Connor's last-minute recusal left the Court equally divided, though, affirming the result below by rule. ${ }^{197}$ Vital questions like whether and how the tribes could change uses, market excess water, or forfeit it, were never addressed. ${ }^{198}$ For these and other issues, the combination of a state forum and federal common law brought only confusion ${ }^{199}$ and debates over judges' 'finding' rather than making the law. ${ }^{200}$

193. See MacDonncll, supra note 63, at 342-44; McElroy \& Davis, supra note 18, at 62428, 648; Robison, supra note 128, at 270-77; Thorson et al., Dividing Western Waters II, supra notc 18 , at 470 .

194. See Mergen \& Liu, supra notc 180 , at $684-85$. A draft opinion by Justicc O'Connor was based in substantial part on Wyoming's bricf. Id.

195. See Mcrgen \& Liu, supra note 180, at 700-01. That aspect of the award below was affirmcd by the Wyoming Supremc Court. See Big Horn 1I, 753 P.2d at 102 (applying an abusc of discretion standard). But it also approved of the lower court's rejection of the special master's interpretation of the treaties as having additional purposes besides irrigation. $C f$. id. at 97 ("Although the treaty did not force the Indians to become farmers and although it clearly contemplates that other activities would be permitted ... the treaty encouraged only agriculture, and that was its primary purpose.").

196. See Mergen \& Liu, supra note 180, at 707-08; Robison, supra note 128, at 286-88.

197. Cf. Mergen \& Liu, supra note 180, at 735-40 (appendix) (reprinting Justice O'Connor's draft opinion showing a "factored" approach to PIA, together with a new "sensitivity" factor limiting quantities for Indians to that which is needed and not too injurious to other users in the basin).

198. See Mergen \& Liu, supra notc 180, at 702-05, 740; Robison, supra note 128, at 293. On remand, the change-of-use issuc (along with another, less precise qucstion) re-emerged, drawing a fractious and "confusing" response from the Wyoming Supreme Court in Big Horn IV. See MCCOOL, supra note 82, at 19; Robison, supra note 128 , at 290.

199. Big Horn IV's 3-2 majority agreed to reverse the lower court's holding that the tribes could change uses without state approval but failed to agree on the extent of the state enginecr's authority over the tribes' reserved rights generally. See Big Horn IV, 835 P.2d at 300-03 (Golden, J., dissenting) (offering a "guide" to the plurality of opinions and disparate rationales bchind the votes to reverse); Robison, supra note 128 , at $290-91$.

200. Cf. PURCELL, supra note 160, at 303 (noting that Justice Brandeis was concerned with limiting federal common law-making but that Erie never resolved the proper scope of that power). As to fedcral courts, "[m]ost theories fall into two catcgories: (1) those that argue that federal courts have inherent power to make federal common law in certain circumstances; and (2) those that argue that federal courts have power to make federal common law only if Congress has delcgated power to them to do so." Bellia, supra note 92, at 827 . But for state courts, they "could no more comply with a command that they adjudicate claims arising under federal law but make no new federal law with respect to them than they could comply with a command that they both decide a case and not decide it." $I$ d. at 830 . Thus, so long as state courts are bound to adjudicate fed- 
What was finally settled about the water rights in the Big Horn adjudication? Presumably Wyoming could change the state law rights there declared, but what of the federal law declared? ${ }^{201}$ And what in the judgment was federal law-the interpretation of the Ft. Bridger treaties? ${ }^{202}$ The denial of groundwater rights? ${ }^{203}$ The PIA standard's Janusfaced application to that reservation ${ }^{204} \mathrm{~A}$ federal court convinced the Big Horn opinions were wrong on any of this would rightly reject them. ${ }^{205}$ But what about a later state court? That contingency arose three years later when the Wyoming Supreme Court could not form a majority on the quite practical question of whether the state's change-of-use constraints applied to tribal applicants. ${ }^{206}$

Several considerations diminish the value of a judgment where the federal common law of waters' uncertain contours were traced in a state forum. ${ }^{207}$ First, state courts are not constrained in their resolution of fed-

eral claims, see, e.g., Felder v. Casey, 487 U.S. 131, 151 (1988), state court adjudication of reserved rights will present 'reverse-Erie' problems.

201. Cf. Bellia, supra note 92 , at 908 ("[W] hen a state court purports to enforce the 'supreme Law of the Land,' it must seek to enforce its best understanding of existing principles of federal law."); Clermont, supra note 24, at 57 ("[E]very question of law posed to every actor in a system of federalism is preceded by the choice-of-law problem of whether the legal question is a matter of state or federal law, a problem whose resolution is usually obvious but sometimes excruciatingly difficult."); Ficld, supra note 87, at 927 ("The cases rarely address directly the courts' power to make federal common law... . The case law creates the overall impression that courts' power to create federal rules is less broad than Congress's power, but no clear picture emerges of the limits of federal common law.").

202. See supra notes $188-91$ and accompanying text.

203. Some state high courts have distinguished the Big Horn ruling. See In re Gila River System, 989 P.2d 739, 745 (Ariz. 1999); Conf'd Salish and Kootenai Tribes v. Stults, 59 P.3d 1093, 1094 (Mont. 2002).

204. The Court's adoption of the Special Master's PIA solution in Arizona v. California, 373 U.S. 546, 600-01 (1963), was notoriously back-handed and cryptic, see Myers, supra note 112 , at 71 , and has since been rejected by at least one state court. See In re Gila River System, 35 P.3d 68, 77-79 (Ariz. 2001).

205. See Kevin M. Clermont, Degrees of Deference: Applying vs. Adopting Another Sovereign's Law, 103 CORNELL L. REV. 243, 273 (2018) ("A state court's decision as to the content of federal law... has no precedential effect at all in federal court."); cf. Baude, supra note 100, at 1844 ("Judgments become binding law, not opinions. Opinions merely explain the grounds for judgments, helping other people to plan and order their affairs.") (cmphasis in original).

206. See Big Horn IV, 835 P.2d at 300-03 (Golden, J., dissenting) (noting that the majority on each of two points of reversal included at least one judge who disagreed with the rationale for the reversal) ("At least three Justices . . . conclude that the state engineer should regulate the water on the entire reservation, but the law that should applied is federal, not state law . . . Pragmatically, it is difficult to imagine how this opinion can be implemented.").

207. Cf. Clermont, supra note 205 , at $274-75$ (noting that application of federal law by state court calls for "pretty blind adherence by the state actor to the federal government's views of that law's content" but that "state interests control any adoption of federal law" and that state courts would "tend to be bound under stare decisis by decisions within that state's hierarchy of courts as to the federal law's content"). 
eral claims by Article III, although any federal court review thereof must be. ${ }^{208}$ Second, the stream adjudications are by nature "preventive" and, because of how fact intensive they are, of quite uncertain preclusive scope. ${ }^{209}$ Finally, "there is no obvious line distinguishing judicial acts that make federal common law from judicial acts that merely apply preexisting federal law." 210 This can be especially problematic when an elected judiciary duty-bound to serve the state's interests is interpreting reserved rights to waters. ${ }^{211}$ So what is the binding effect of any of these judgments? The Indians' antagonists in Wyoming insisted that any more water ceded to the tribes would come from them 'gallon-for-gallon,'212 and that federal law did not command that the tribes be granted instream flows. ${ }^{213}$ Yet federal common law was (and is) settled that Indian treaty purposes are necessarily bilateral and that tribal rights were not created by those treaties but rather retained therein. ${ }^{214}$ The Wyoming courts' judgments were, in short, incomplete at best and likely questionable on their merits. And that should prompt a deeper reckoning: can judgments like these ever actually refine or harden legal entitlements to Western waters?

208. See Asarco, Inc. v. Kadish, 490 U.S. 605, 617 (1989). Even when adjudicating a federal claim, state courts often play roles vastly different from those of federal courts. See Helen Hershkoff, State Courts and the "Passive Virtues": Rethinking the Judicial Function, 114 HARV. L. REV. 1833, 1842-76 (2001).

209. See Samuel L. Bray, Preventive Adjudication, 77 U. CH1. L. REV. 1275, 1279, 1295-96 (2010) (defining "preventive adjudication" as litigants seeking "to avoid future harm by having a court resolve legal indeterminacy without issuing a command" and noting that those resolving "fact-based indeterminacy" generally have less issue-preclusive effect").

210. Bcllia, supra note 92 , at 835 .

211. See Hershkoff, supra note 208, at 1882-1905; ROBERT F. WILLIAMS, THE LAW OF AMERICAN STATE CONSTITUTIONS 283-301 (2009). "State courts are not simply "little" versions of the federal courts. A large majority of state judges face the electorate in either partisan, nonpartisan, or mcrit-retention elections." WILliamS, THE LAW OF AMERICAN STATE CONSTITUTIONS 285. See also Burt Neuborne, The Myth of Parity, 90 HARV. L. REV. 1105, 1120-21 (1977). Of course, raising questions of bias (or relative competence) has always bcen easier than answering them. See Michael E. Soliminc, The Future of Parity, 46 WM. \& MARY L. REV. 1457, 1462-72 (2005).

212. See Wyoming Cert. Petition, supra note 178, at 20-23; cf. United States v. New Mexico, 438 U.S. 696, 705 (1978) (observing that federal reserved water rights "will frequently require a gallon-for-gallon reduction in the amount of water available for water-needy state and private appropriators").

213. See Wyoming Cert. Petition, supra note 178, at 12-28; Brief for Petitioner, State of Wyoming v. United States, 1989 WL 1127591 (March 9, 1989), at 10-16.

214. See United States v. Winans, 198 U.S. 371, 379-84 (1905); see also Brief for the United States, State of Wyoming v. Unitcd States, 1989 WL 1127611 (April 12, 1989), at 8-11; Washington v. Wash. State Comm. Passenger Fishing Vessel Ass'n, 443 U.S. 658, 675 (1979); Tulee v. Washington, 315 U.S. 681, 684-85 (1942); Seufert Bros. Co. v. United States, 249 U.S. 194, 19899 (1919). 
Concurrent jurisdiction, as framed by Colorado River abstention ${ }^{215}$ and San Carlos Apache's faith in the certiorari power, ${ }^{216}$ is leaving reserved rights in a permanently unsettled legal state. This indirectly clouds related appropriative rights too. The Big Horn River, a tributary of the Yellowstone -itself tributary to the Missouri-is part of a large, interconnected system that changes abruptly and routinely in character, extent, and value. ${ }^{217}$ Federal and state interests in its governance no doubt converge at points. But they frame and meet aridity's challenges with inevitably different sovereign and proprietary priorities. ${ }^{218}$ Legal judgments can create little repose in a context like this. ${ }^{219}$

Of course, PIA is at least $a$ standard. 220 "Despite the hundreds of treaties establishing, enlarging, and diminishing Indian land reservations, which rarely mention water, Congress as a general matter has said even less than the Supreme Court on the subject of Indian reserved water rights." 221 Legal uncertainty in tribal authority has rarely been remedied by Congress. ${ }^{222}$ But these challenges are sure to grow still more acute in the inevitable preclusion and finality disputes that will trail the basin judgments into a future of widening scarcity. ${ }^{23}$ Can these judgments

215. See supra note $149-60$ and accompanying text.

216. The Court's certiorari docket necessarily consists in a small (and dwindling) fraction of cases within its jurisdiction. Simple error correction, thus, has long been thought an ineffective use of the Court's resources. See SAMUEL ESTREICHER \& JOHN SEXTON, REDEFINING THE SUPREME CourT's Role: A Theory of MANAGING The Federal Judicial Process 95 (1986). San Carlos Apache's faith in the certiorari power to protect specific tribal rights was, thus, curious to say the least.

217. See DONALD WORSTER, RIVERS OF EMPIRE: WATER, ARIDITY, AND THE GROWTH OF THE AMERICAN WEST 267-69 (1985).

218. Even stream adjudications of tributaries, like that of the Gila which excluded groundwater and all downstream consequences, have grown to epic proportions and complexity. See Feller, supra note 131, at 405; Thorson et al., Dividing Western Waters II, supra note 18, at 34850 .

219. Even assuming defensible judgments can be reached, inter-branch frictions will inevitably engulf them. See Baude, supra note 100, at 1832-34; Kevin C. Walsh, Judicial Departmentalism: An Introduction, 58 WM. \& MARY L. REV. 1713 (2018).

220. Several lower court opinions quantifying reserved rights by way of irrigability predated Special Master Rifkind's report in Arizona v. California. See, e.g., United States v. Ahtanum Irr. Dist., 236 F.2d 321 (9th Cir. 1956); Conrad Invest. Co. v. United States, 161 F. 829 (9th Cir. 1908). Arizona was the Supreme Court's first adoption of PIA.

221. Anderson, supra note 145 , at 1153 .

222. See Lloyd Burton, American Indian Water Rights AND the Limits of LAW (1991); MCCOOL, supra note 82, at 187-91; Anderson, supra note 24, at 213-14.

223. See, e.g., In re Gila River System and Source, 127 P.3d 882, 886-87 \& n.5 (Ariz. 2006) (describing six distinct issues on preclusive effect of federal consent decree as to tribes not party to underlying action); In re Yakima River Drainage Basin, 296 P.3d 835, 837-59 (Wash. 2013) (weighing the preclusive scope of a fifty year-old federal court decree that raised but did not adju- 
bind others not party to them? Should federal or state preclusion law govern subsequent litigation of reserved or appropriative rights that limit one another? ${ }^{224}$ What is the force of one of these judgments in a federal court? ${ }^{225}$ Article III court judgments may (generally) be immune from legislative revision, ${ }^{226}$ but some states' judicial powers are less fully independent of their legislatures. ${ }^{227}$ Does that render these judgments even less secure?

The specter of preclusion law, of course, amplified the incentives to litigate in the basin adjudications. ${ }^{228}$ Going forward it will plague any assertion of new uses that should (or could) have been raised in those adjudications. ${ }^{229}$ In this light, though, the judgments themselves may scarcely avoid attack long enough to have been worth their cost. ${ }^{230}$ Any judgment is vulnerable to collateral attack under the right (change of) conditions. ${ }^{231}$ Judgments adjudicating title to a thing with cryptic territo-

dicate tribal water rights, reported at United States v. Ahtanum, 330 F.2d 897 (9th Cir. 1964)); Dcpt. of Ecology v. Yakima Rescrv. Irr. Dist., 850 P.2d 1306 (Wash. 1993).

224. Thus, although the Court has held that "nonmutual offensive" collateral cstoppel ordinarily will not bind the United States, see United States v. Mendoza, 464 U.S. 154, 162-63 (1984), the federal full faith and credit statute ordinarily will bind a federal court to the extent statc courts are bound by their own preclusion rules. See Kremer v. Chem. Constr. Corp., 456 U.S. 461 (1982) (citing 28 U.S.C. § 1738); Migra v. Warren City Sch. Dist. Bd. of Educ., 465 U.S. 75, 78-79 (1984). Still, the scope of the claims for relief underlying such judgments and their preclusive force are open to interpretation. See Nevada v. United States, 463 U.S. 110, 130 (1983) ("Definitions of what constitutes the 'same cause of action' have not remained static over time.").

225. The full faith and credit statute bars a state court loser from refiling in federal court, but certain jurisdictional statutes have acquired their own more specific preclusion doctrines. See Matsushita Elec. Indus. Co. v. Epstein, 516 U.S. 367, 373-80 (1996); Marrese v. Amer. Acad. of Orthopaedic Surgcons, 470 U.S. 373, 379-86 (1985); Allen v. McCurry, 449 U.S. 90, 95-96 (1980).

226. See, e.g., Plaut v. Spendthrift Farm, Inc., 514 U.S. 211 (1995); United States v. Sioux Nation, 448 U.S. 371, 402-16 (1980). The Supreme Court's equitable apportionment judgments may be an exception, see supra note 104 and accompanying text, although that has not been squarcly tested in court. See Douglas L. Grant \& Brett Birdsong, Apportionment by Congress, in WATERS AND WATER RIGHTS $\S 47.01$ (3d ed. 2017).

227. See WILLIAMS, supra note 211 , at 298-301.

228. See Feller, supra notc 131, at 431-32; Tarlock, supra note 131, at 282-88; Thorson ct al., Dividing Western Waters II, supra note 18, at 436-38.

229. See, e.g., Arizona v. California, 530 U.S. 392 (2000); In re Yakima River Drainagc Basin, 296 P.3d 835 (Wash. 2013).

230. Rough estimates put the Big Horn adjudication in the hundreds of millions in total cost. See Robison, supra note 128, at 309 n.443. Although the Court added in a footnote in Nevada that "[t]he policies advanced by the doctrine of res judicata perhaps are at their zenith in cases conccrning real property, land and water," Nevada, 463 U.S. at 129-30 n.10, it showed no awareness of that policy's emergence from real property's possessory naturc. See James Y. Stern, Property, Exclusivity, and Jurisdiction, 100 VA. L. REV. 111, 120-21 (2014).

231. See REstatement (2d) JudgmentS $§ 73$, cmt. b (1982) ("When an unforesecn or uncontrollable interaction occurs between the judgment obligor and the surrounding circumstances, 
riality, ${ }^{232}$ where notice is not provided to nonresident users, ${ }^{233}$ and where the forum applied another sovereign's law, ${ }^{234}$ will be open to those attacks. ${ }^{235}$ As fast-changing environments undermine whatever repose these judgments did offer, ${ }^{236}$ increasing pressures to reallocate waters as best uses evolve technologically or culturally will challenge our obsession with protecting private rights from public expropriation. Part III introduces that dimension to our jurisdictional calculus.

\section{WATER RIGHTS TAKINGS: Claims WITHOUT A FORUM?}

The Supreme Court has struggled without obvious success to pattern the doctrinal and jurisdictional norms governing complaints that some government entity has "taken" property by regulating, damaging, or interfering with it. ${ }^{237}$ Periods of relative settlement ${ }^{238}$ have been quickly

the balance between burden and benefit can be disturbed. If the disturbance assumes substantial proportion, redress by modification may be appropriate.").

232. River systems as integrated wholes may defy categorization by situs versus non-situs states, but every Western state is both up- and downstream of another. Cf. Alfred P. Hill, The Judicial Function in Choice of Law, 85 COLUM. L. REV. 1585, 1628-29 (1985) ("The situs jurisdiction can normally protect itself... by reason of its physical power over local immovables, putting aside the vexing problem of the deference duc to foreign judgments. In any event, these are matters in which all jurisdictions have a stake, for the non-situs forum of today may be the non-forum situs of tomorrow."); Idaho v. Oregon, 462 U.S. 1017, 1027-29 (1983) (holding that Idaho has an interest in the anadromous fish runs of the Snake River that may be protected by equitable apportionment).

233. Cf. Mullane v. Central Hanover Bank \& Trust Co., 339 U.S. 306, 317-20 (1950) (holding that due process entails more than "constructive notice" in adjudicating nonresidents' rights to a resident property).

234. A federal court sitting in diversity may not abstain simply because the state law issues in its case are unsettled. See Meredith v. Winter Haven, 320 U.S. 228, 234 (1943). And a state court may, on occasion, be compelled to take jurisdiction of an action involving another state's law. See, e.g., Hughes v. Fetter, 341 U.S. 609, 611 (1951). But a foreign jurisdiction's cquity decree effectuating a third jurisdiction's law (the federal common law of reserved rights) surely prescnts abundant opportunities to a second forum state to refuse enforcement. See RESTATEMENT (2D) CONFLICTS OF LAWS $\$ 99$ (1971) ("The local law of the forum determines the methods by which a judgment of another state is enforced."); Baker v. General Motors Corp., 522 U.S. 222, 235 (1998) ("Orders commanding action or inaction have been denied enforcement in a sister State when they purported to accomplish an official act within the exclusive province of that other State or interfered with litigation over which the ordering Statc had no authority.").

235. See infra notes $452-64$ and accompanying text.

236. See Tarlock, supra note 131 , at $286-88$.

237. The canon of this struggle now includes Koontz v. St. Johns River Water Management District, 570 U.S. 595 (2013), Horne v. Department of Agriculture, 569 U.S. 513 (2013), San Remo Hotel, L.P. v. San Francisco, 545 U.S. 323 (2005); City of Monterey v. Del Monte Dunes at Monterey, 526 U.S. 687 (1999), City of Chicago v. International College of Surgeons, 522 U.S. 156 (1997); Nollan v. California Coastal Commission., 483 U.S. 825 (1987), MacDonald, Sommer \& Frates v. Yolo County, 477 U.S. 340 (1986), Williamson County Planning Commission v. Hamilton Bank, 473 U.S. 172 (1985), San Diego Gas \& Electric Co. v. City of San Diego, 450 
overrun by renewed turmoil. ${ }^{239}$ As often as the Court has insisted that state law takings claims ordinarily belong in state forums, ${ }^{240}$ it has repeatedly qualified the norm. ${ }^{241}$ The confusion stems in part from property as a constitutional concept. ${ }^{242}$ But it is also among the clearest reflections of our divided sovereignty and its uncertain significance to concurrent jurisdiction. As several contentious disputes have lately shown, when the property claim being asserted is a water right the structure of the entitlement itself can confound even the best efforts at an adjudication. Section A sets the baseline while Section B traces water rights' special troubles.

\section{A. Denominators and Dual Sovereignty in Constitutional Property}

Regulatory takings doctrine for our purposes begins at Justice Brennan's synthesis in Penn Central Transportation v. City of New York. ${ }^{243}$ Bolstered by scholars, ${ }^{244}$ the justices all agreed that property regulation can become so burdensome as to justify compensation. ${ }^{245}$ Beyond this proto-utilitarian turn (challenging in its own right ${ }^{246}$ ), though, the majority invoked the "character" of governmental action, contrasting "physical invasion[s]" like flooding or overflights with taxes, fees, and other purely pecuniary burdens. ${ }^{247}$ Where the latter receded into the ocean of

U.S. 621 (1981), Agins v. City of Tiburon, 447 U.S. 255 (1980), Penn Central Transportation Co. v. City of New York, 438 U.S. 104 (1978), and Blanchette v. Connecticut General Insurance Corps., 419 U.S. 102 (1974).

238. In Lingle v. Chevron, 544 U.S. 528 (2005), Court held that any challenge to a regulation's purpose or cfficiency was not a proper "takings" claim (if anything, it was a duc process claim) and that the only takings claim for which federal courts could properly cntertain jurisdiction required that a claimant first establish just what "compensation" was due and denied. See id. at 536-48.

239. See infra note 262 and accompanying text

240. See Agins, 447 U.S. at 260-63; Williamson County, 473 U.S. at 186; San Remo Hotel, 545 U.S. at 346-48.

241. See Thomas W. Merrill, Anticipatory Remedies for Takings, 128 HARV. L. REV. 1630, 1660-63 (2015)

242. See Stewart E. Sterk, The Federalist Dimension of Regulatory Jurisprudence, 114 YALE L.J. 203 (2004).

243. 438 U.S. $104,122-38$ (1978).

244. See Penn Central, 438 U.S. at 123-28 (discussing Frank I. Michelman, Property, Utility and Fairness: Comments on the Ethical Foundations of "Just Compensation" Law, 80 HARV. L. REV. 1165 (1967); Joseph L. Sax, Takings and the Police Power, 74 YALE L.J. 36 (1964)).

245. See Penn Central, 438 U.S. at 127-28 (fitting within one of "scveral factors that have particular significance" whether a regulation "so frustrate[s] distinct investment-backed expectations" that it becomes a taking).

246. See infra note 253 and accompanying text.

247. See Penn Central, 438 U.S. at 124-25. 
"economic" regulation not to be closely scrutinized, ${ }^{248}$ physical invasions became a discrete hallmark of regulatory takings. ${ }^{249}$ Likewise, weighing the burdens on owners became a "whole parcel analysis" of the sum total of a property's burdens and offsetting benefits. ${ }^{250}$

On both the unfair burden and physical invasion tracks, jurisdiction quickly became a central question. ${ }^{251}$ Conceptually, both inquiries must proceed from a baseline: whether the property at stake included the entitlement which the intervention is alleged to have appropriated or denied. Land use cases had presented variants of this denominator question before Penn Central. ${ }^{252}$ But in Penn Central's wake it became essential. ${ }^{253}$ It is at least presumptively an inquiry into the law vesting the entitlement(s) at issue $\mathrm{e}^{254}$ and distinguishing procedural and remedial dimen-

248. See Molly S. McUsic, The Ghost of Lochner: Modern Takings Doctrine and Its Impact on Economic Legislation, 76 B.U. L. REV. 605 (1996); Lynda J. Oswald, Cornering the Quark: Investment-Backed Expectations and Economically Viable Uses in Takings Analysis, 70 WASH. L. REV. 91 (1995); $c f$. JOHN HART ELY, DEMOCRACY AND DisTRUST: A THEORY OF JUDICIAL REVIEW 14-15 (1980) (observing that "substantive due process" scrutiny of economic and social legislation was "universally acknowledged to have been constitutionally improper"). Mostly. In Koontz v. St. Johns River Water Management District, 570 U.S. 595 (2013), the Court held that an "exacted" development fee can, in some contexts, merit clevated scrutiny. See id. at 613-19.

249. See Arkansas Game and Fish Comm'n v. United States, 568 U.S. 23, 31-38 (2012); Nollan v. Cal. Coastal Comm'n, 483 U.S. 825, 831-32 (1987); Loretto v. Teleprompter Manhattan CATV Corp., 458 U.S. 419, 433-36 (1982); Kaiser Aetna v. United States, 444 U.S. 164, 179-80 (1979); DAVID A. DANA \& THOMAS W. MERRILl, PROPERTY: TAKINGS 94-99 (2002).

250. See DANA \& MERrill, supra note 249, at 121-64. An exception to Penn Central's "whole parcel" analysis was made for the rare regulation that eliminates "all economically viable" uses of property. See Lucas v. South Carolina Coastal Council, 505 U.S. 1003 (1992) (holding that such regulations are "per se" takings).

251. For state court claims brought to the Supreme Court by certiorari, the Court is statutorily barred from hearing claims absent a "final" order or disposition-a bar that figured prominently in several key cases. See San Diego Gas \& Elect. Co. v. City of San Diego, 450 U.S. 621,633 (1981) (Rchnquist, J., concurring) (discussing 28 U.S.C. $\S 1257$ ). For federal courts, the Tucker Act and ripeness principles combine to exclude most takings claims from the district courts. See Hodel v. Virginia Surface Mining \& Reclamation Ass'n., 452 U.S. 264 (1981); Penn Central, 438 U.S. 137-38 (concluding that transfcrable devclopment rights, though they may not have constituted just compensation if a taking had occurred, nonetheless "mitigate whatever financial burden the law has imposed on appellants" and for that reason render the final burden impossible to calculate).

252. See Kenneth B. Bley \& Tina R. Axlerad, The Search for Constitutionally Protected "Property" in Land-Use Law, 29 URB. LAW. 251 (1997); Oswald, supra note 248, at 99-101.

253. Often referred to as the "denominator problem" casting what was possessed $(y)$ versus what was taken $(x)$ as the integers of an arithmetic fraction-rcgardless of numeraire-where the nearer $x / y$ comes to 1 the greater the probability of a taking, the construct forces courts to adopt either a subjective or an objective approach to $y$. See Richard A. Epstein, Lucas v. South Carolina Coastal Council: A Tangled Web of Expectations, 45 STAN. L. REV. 1369 (1993); John E. Fee, Unearthing the Denominator in Regulatory Takings Claims, 61 U. CHI. L. REV. 1535 (1994).

254. See Jamison E. Colburn, Splitting the Atom of Property: Rights Experimentalism as Obligation to Future Generations, 77 GEO. WASH. L. REV. 1411, 1415-39 (2009); cf. Board of 
sions therein brings complex choice of law and forum issues. ${ }^{255}$ For if some ostensible burden may still be invalidated, nullified, or mitigated by some other forum's judgment that could temper or even dispose of the claim itself. ${ }^{256}$

If a state adjudication resolves a federal claim, ${ }^{257}$ though, our federalism's full faith and credit requirements should preclude re-litigation of that very claim. ${ }^{258} \mathrm{~A}$ core case in full faith and credit is the state court judgment-loser suing in federal court. ${ }^{259}$ Yet for property burdens grounded in state law and challenged in state court, the "virtually unflagging obligation of the federal courts to exercise the jurisdiction given them" 260 would then consist solely in the Supreme Court's review by certiorari. ${ }^{261}$ There would be no original jurisdiction in a federal forum and the chances of appellate review would be slim.

Regents v. Roth, 408 U:S. 564, 576-78 (1972) (conceiving of property as being vested by onc source of law and burdened or impaired by other(s)). Although the American founders' understanding of property was quite different from ours, it was widely understood that property's ultimate origins were in positive law. See DANA \& MERRILL, supra note 249, at 9-25.

255. See Bley \& Axelrad, supra notc 252, at 271-73 (noting that a local government could elect to make all use rights discretionary with the government and thereby insulate itself from takings liability or at least climinate a federal forum). Compare Williamson County Regional Planning Comm'n v. Hamilton Bank, 473 U.S. 172, 186 (1985) ("[A] claim that the application of government regulations effects a taking of a property interest is not ripe until the government entity charged with implementing the regulations has reached a final decision regarding the application of the regulations to the property at issue."), with Fuentes v. Shevin, 407 U.S. 67, 75-82 (1972) (holding that state law proccdures enabling pre-judgment scizures of personal property "at the same moment that the defendant reccives the complaint sceking repossession of property through court action," although "derived from . . . ancient possessory action" in replevin, violated the Court's due process doctrines requiring some kind of hearing prior to the property deprivation).

256. This was the reasoning in Williamson County, 473 U.S. 172 (1985) and in MacDonald, Sommer \& Frates v. Yolo County, 477 U.S. 430 (1986), and, with respect to certain federal claims, in Ruckelshaus v. Monsanto Co., 467 U.S. 986 (1984). It was also the majority's reason for holding the claim premature in Penn Central. See Penn Central Transp. Co. v. City of New York, 438 U.S. 104, 135-38 (1978).

257. See FALLON ET AL., supra note 8, at 1103-27; WRIGHT \& KANE, supra note 87, at 31417 (discussing various rules of exhaustion of state nonjudicial remedics). This is not unlike $P$ ullman or Colorado River abstention in effect. See supra notes 156-58 and accompanying text.

258. See San Remo Hotel, L.P. v. City \& Cty. of San Francisco, 545 U.S. 323, 347-48 (2005) (holding that federal full faith and credit statute, 28 U.S.C. $\S 1738$, bars takings claim litigated in California courts from being re-litigated in federal court); see also Kremer v. Chem. Constr. Corp., 456 U.S. 461, 485 (1982); England v. Louisiana State Bd. of Med. Exam'rs, 375 U.S. 411,419 (1964).

259. See Underwriters Nat'l Assurance Co. v. North Carolina Guar. Ass'n, 455 U.S. 691 , 703-04 (1982); Kremer, 456 U.S. at 466-79; Allen v. McCurry, 449 U.S. 90, 94-98 (1980).

260. Colorado River Water Conserv. Dist. v. United States, 424 U.S. 800,817 (1976).

261. Cf. Dolan v. City of Tigard, 512 U.S. 374, 392 (1994) (observing that takings claims should not be "relegated to the status of poor relation" to other Bill of Rights claims routinely heard in federal court). 
Quite remarkably, thus, the Supreme Court has increasingly allowed that such claims, when filed first in federal court and "ripe" for adjudication, can be heard there despite the presence of unresolved state law questions. ${ }^{262}$ Professor Merrill even argued that these cases amount to an alternative jurisdictional track. ${ }^{263}$ If so, that track widened in 2017 with Murr v. Wisconsin. ${ }^{264}$ The development restrictions challenged in Murr arose from a floodplain protection scheme designed to limit development along the St. Croix River. ${ }^{265}$ Petitioners challenged restrictions on small lot sale/development, a burden Wisconsin law declared should be measured against all lots held in common ownership. ${ }^{266}$ The majority through Justice Kennedy held that denominator determinations like this could not be made solely by recourse to extant local law but, instead, should face a multi-factored doctrinal test the Murr Court fashioned. ${ }^{267}$ And this "elaborate test looking not only to state and local law," but also to factors taken from the Court's own past takings opinions, ${ }^{268}$ reshaped the denominator inquiry into one without a presumptive forum. With underlying entitlements like water rights, however, a compound legal basis in both state and federal law is going to bring acute jurisdictional troubles.

\section{B. Tales from the Klamath: Water Rights as Property}

A takings dispute so byzantine could only have arisen from our wa-

262. See, e.g., Knick v. Twp. of Scott, 139 S. Ct. 2161 (2019) (holding that claim brought under $\S 1983$ need not be litigated in state forum if it is challenging an "act of taking" that has already occurred); Palazzolo v. Rhode Island, 533 U.S. 606 (2001) (claim brought as $\$ 1983$ action challenging state and local land use restrictions); City of Chicago v. Int'l Coll. of Surgeons, 522 U.S. 156, 164-74 (1997) (finding that removal of claim against city's landmark controls for invalidity under state law and seeking federal takings liability was appropriate under 28 U.S.C. $\S 1441$ (a) and that federal courts could excrcise supplemental jurisdiction under 28 U.S.C. $\$ 1367$ (a) to hear state law claims because neither Burford nor Pullman abstention required the court to defer to a state forum); Suitum v. Tahoe Reg'l Planning Agency, 520 U.S. 725, 735-44 (1997) (holding that takings claim against development restrictions was ripe under 42 U.S.C. $\$ 1983$ notwithstanding the authority's grant of as-yet-untraded transferable development rights and claim in complaint that agency's refusals to act were unauthorized by law); $c f$. Cty. of Allegheny v. Frank Mashuda Co., 360 U.S. 185 (1959) (diversity action in federal court challenging validity of state condemnation).

263. See Merrill, supra note 241, at 1634-36.

264. 137 S. Ct. 1933 (2017).

265. See id. at 1939-40.

266. See Id. at 1941 (citing Zealy v. Waukesha, 548 N.W.2d 528 (Wis. 1996)).

267. See Id. at 1945-50 (holding that "reasonable" owner expectations, applicable state or local law, the timing of any pertinent legal changes, the property's physical characteristics, and the total value of regulated property comprised the "appropriate multi-factor standard" for establishing the relevant denominator).

268. Id. at 1950 (Roberts, C.J., joined by Thomas and Alito, JJ., dissenting). 
ters federalism and its legal complexity. ${ }^{269}$ The Reclamation Act has always required the U.S. Bureau of Reclamation (Bureau) to obtain under state law whatever water rights its projects required. ${ }^{270}$ This aspect of the Act has remained gospel in reclamation states. ${ }^{271}$ But since 1937 and a stunning account of the Bureau's role in "project water" disputes in Ickes v. Fox, ${ }^{272}$ reclamation deliveries have been said to vest a kind of equitable right in those who put the water to beneficial use. ${ }^{273}$ The Bureau's status under Ickes as mere "carrier and distributor of the water"274 has posed incorrigible questions about its place amid competing state and federal law and interests. 275

It all began with a 2001 Bureau decision to deliver only about $10 \%$ of the project water and to do that late in the season-owing to obliga-

269. On the combined state/federal structure of our takings law, see Mark Fenster, The Stubborn Incoherence of Regulatory Takings Law, 28 STAN. ENVTL. L. REV. 525 (2009). Another exemplar, the McBryde Sugar litigation from Hawa''i and the Ninth Circuit, might have done equally well in this role. McBryde Sugar involved a judicial declaration of water rights seemingly in derogation of Hawai'i customary and common law, see McBryde Sugar Co. v. Robinson, 504 P.2d 1330 (Haw. 1973), a collateral federal court action alleging among other things violations of due process, see Robinson v. Ariyoshi, 441 F. Supp. 559 (D. Haw. 1977), an appeal resulting in six certified questions to the state supremc court, see Robinson v. Ariyoshi, 658 P.2d 287 (Haw. 1982), a federal court injunction requiring the state to bring eminent domain proceedings if it sought to enforce its original decision, see Robinson v. Ariyoshi, 753 F.2d 1468 (9th Cir. 1985), a certiorari grant vacating that injunction and remanding in light of Williamson County, see Ariyoshi v. Robinson, 477 U.S. 902, 902 (1986), a defiant rejection by the district court of the state's newly enacted water code as having mooted the case, see Robinson v. Ariyoshi, 676 F. Supp. 1002 (D. Haw. 1987), and the eventual dismissal of the case by the Ninth Circuit as moot. See Robinson v. Ariyoshi, 887 F.2d 215 (9th Cir. 1989).

270. See Benson, supra notc 34 , at $374-82$.

271. See WILKINSON, supra note 34, at 247-49; Amy K. Kelley, Developments in Water and Environmental Law - Staging a Comeback-Section 8 of the Reclamation Act, 18 U.C. DAVIS L. REV. 97 (1984).

272. 300 U.S. 82 (1937).

273. Ickes, 300 U.S. at 94-95; see also Fox v. Ickcs, 137 F.2d 30 (D.C. Cir.), cert. denied, 320 U.S. 792 (1943).

274. Ickes, 300 U.S. at 95.

275. Reclamation Act $\S 8$ 's enigma has consisted in its declaration that the United States must "procecd in conformity" with "the laws of any State or tcrritory relating to the control, appropriation, use, or distribution of water used in irrigation, or any vested right acquired thereunder." Pub. L. No. 57-161, 32 Stat. 388, 390 (1902), (codified at 43 U.S.C. $\S 383$ ). But $\S 8$ also states "[t]hat the right to usc of water acquired under [the Act] shall be appurtenant to the land irrigated, and beneficial use shall be the basis, the measure, and the limit of the right," id., thereby seemingly making use of delivered water into a (federal) condition on its delivery. See, e.g., Ncbraska v. Wyoming, 325 U.S. 589, 611-15 (1945) (reviewing the United States' claim as appropriator under both riparian and prior appropriation law). And the balance of state and federal law thercin has become increasingly problematic as use shifting has grown more prevalent in the arid states. 
tions under the Endangered Species Act (ESA), ${ }^{276}$ tribal treaties, and the fact that its contractual partners had long been on notice that scarcity could cut deliveries. ${ }^{277}$ The Klamath basin spans the Oregon-California border. A 1957 interstate compact ${ }^{278}$ came only after it had been carved up by reclamation infrastructure and diverted to irrigators. ${ }^{279}$ The project water deliveries had once seemed untouchable. ${ }^{280}$ "For decades, Klamath Basin landowners generally received as much water for irrigation as they needed. In severe drought years, they simply received somewhat less." 281 But federal authority and inertia are two different things. ${ }^{282}$

As mentioned, doctrines of reclamation law have long sent conflicting signals about state water law's significance to federal law. ${ }^{283}$ In $\mathrm{Ne}$ vada v. United States, ${ }^{284}$ the Supreme Court held that the Bureau had no discretion to reallocate water the United States had originally sued in federal court to obtain for irrigation under state law because it remained bound by that earlier decree. ${ }^{285}$ The Nevada Court was evidently un-

276. Gray, supra note 27 , at 23. Attributing a discretionary decision to the Bureau's 2001 actions is significant to the contract claims. In April 2001, Judge Armstrong of the U.S. District Court for the Northern District of California enjoined the Bureau from implementing its operations plan that year, citing its Endangered Spccies Act $\S 7$ dutics. See Pac. Coast Fed'n of Fishermen v. U.S. Bureau of Reclamation, 138 F. Supp. 2d 1228 (N.D. Cal. 2001). Later that month, U.S. District Judge Aiken in Oregon denied the irrigators an injunction to force the deliveries they sought. See Kandra v. United States, 145 F. Supp. 2d 1192 (D. Or. 2001).

277. See Gray, supra note 27, at 23-25.

278. Congress ratified the compact in 1957. See Klamath River Basin Compact, Pub. L. No. 85-222, 71 Stat. 497 (1957).

279. See HOlly Doremus \& A. Dan TARlock, Water War in the Klamath Basin 4453 (2008). As the Colorado River most famously demonstrates, the timing of a compact profoundly affects its character, contents, and legal significance. See ROBERT W. ADLER, RESTORING Colorado River ECOSYSTEMS: A TROUBled SENSE OF IMMENSITY (2007); Patashnik, supra note 128 .

280. See DOREMUS \& TARLOCK, supra note 279 , at 10 (positing that "cultural" claims to the waters of the Klamath Basin were as much or more important than economic measures and that many of the irrigators burdened by the Bureau of Reclamation's eventual reversal and enforcement of the ESA felt betrayed); $c f$. Benson, supra note 34, at 383 ("Western resource users tend to believe that any resource they have used for a long time with little regulation is theirs, even where the law clearly does not recognize that resource as private property.").

281. Klamath Irr. Dist. v. United States, 67 Fed. Cl. 504, 512 (Fed. Cl. Ct. 2005)

282. Duties levied by the Endangered Species Act, NEPA, and several other environmental statutes constrain most federal authorities over waters. See Barbara A. Cosens, Farmers, Fish, Tribal Power and Poker: Reallocating Water in the Truckee River Basin, Nevada and California, 10 HASTINGS W.-NW. J. ENVT'L L. \& POL'Y 89 (2003).

283. See Benson, supra note 34, at 375-80 (discussing California v. United States, 438 U.S. 645 (1978), City of Fresno v. California, 372 U.S. 627 (1963), and Ivanhoe Irr. Dist. v. McCracken, 357 U.S. $275(1958))$.

284. 463 U.S. 110 (1983).

285. See id. at 125-26. The Nevada Court invoked Nebraska v. Wyoming, 325 U.S. 589 (1945), and Ickes v. Fox, 300 U.S. 82 (1937), what it called the "two leading cases," 463 U.S. at 
troubled by its holding's Erie implications. ${ }^{286}$ But if Nevada made federal law by adopting (or applying) the Restatement's preclusion principles, that would surely add another dimension to project water disputes. ${ }^{287}$ For example, the Ninth and Tenth Circuits have both held that the appropriator's beneficial use, not its contractual terms, decides the quantity of an appropriation. ${ }^{288}$ So the United States' peculiar status in this context somewhere between servant and sovereign ${ }^{289}$ probably foreordained the issues arising in the Klamath. ${ }^{290}$ If so, though, more of these disputes are coming.

The raft of claims filed in the U.S. Court of Federal Claims (CFC) arrived while the Klamath Basin adjudication, begun in an Oregon court in $1976,{ }^{291}$ languished. ${ }^{292}$ The United States moved to stay the CFC actions arguing that priorities still to be determined in the basin adjudica-

122, for the proposition that what the United States acquired in its earlicr litigation in Nevada were the rights of those putting the water to beneficial use. See id. at 126.

286. Recall that in Klaxon v. Stentor, 313 U.S. 487, 494-96 (1941), the Court held that a federal court sitting in diversity was bound to apply the forum state's conflicts of law rules-a holding many understood to reach the recognition of judgments as well. Whether the Nevada majority intended to make a federal rule of decision was unstated. Only a mere footnote acknowledging the wide variation in preclusion law's basic principles-and the dramatic shifts in Restatement doctrinc-betrayed any awareness to the vertical choicc of law question presented in Nevada. See Nevada, 463 U.S. at $130 \mathrm{n} .12$. The Court held ycars later that, at lcast as to diversity jurisdiction, federal judgments' preclusive effects are ordinarily a matter of the state law in which the court sits-absent some unique federal interest. See Semtck Int'l, Inc. v. Lockhecd Martin Corp., 531 U.S. 497, 509 (2001).

287. A choice between "applying" another sovereign's law and "adopting" that law as onc's own follows from modern Erie. See Clermont, supra note 205. If Nevada made federal law, any subsequent adjudication of project water would presumably be bound thereby.

288. See United States v. Alpinc Land \& Reservoir Co., 697 F.2d 851 (9th Cir. 1983); Jicarilla Apache Tribe v. United States, 657 F.2d 1126, 1134-41 (10th Cir. 1981). This is now the refrain in some state courts as well. See, e.g., In re Yakima River Drainage Basin, 935 P.2d 595, 599-600 (Wash. 1997). Had it been the contract terms that governed, federal law would have controlled the constructions thereof. See, e.g., Textile Workers Union v. Lincoln Mills, 353 U.S. 448, 455-57 (1957); Clearfield Trust Co. v. United States, 318 U.S. 363, 366-67 (1943); D'oench, Duhme \& Co. v. Fed. Deposit Ins. Corp., 315 U.S. 447, 457-58 (1942).

289. As then-Justice Rehnquist observed in California v. United States, "[i]f the term "cooperative federalism' had been in vogue in 1902, the Reclamation Act . . . would surely have qualified as a lcading example of it." 438 U.S. 645, 650 (1978).

290. See Amy K. Kcllcy \& Reed D. Benson, Federal Reclamation Law, in WATERS AND WATER RIGHTS $\S 41.05$ (3d ed. 2017).

291. See DOREMUS \& TARLOCK, supra note 279 , at 43 . The thirteen irrigation districts and twelve individual uscrs who sued in 2001 claimed damages from the United States in excess of $\$ 1$ billion. See Gray, supra note 27, at 23.

292. The United States' declaratory judgment action on behalf of the Klamath tribes was dismissed in deference to the basin adjudication. See United States v. Oregon, 44 F.3d 758, 76570 (9th Cir. 1994) (citing Arizona v. San Carlos Apache Tribc, 463 U.S. 545 (1983)). By the end of the takings litigation, the Klamath Basin adjudication's end was at least in sight. See Baley v. United States, 134 Fed. Cl. 619, 635 (Ct. Fed. Cl. 2017). 
tion were "required elements of Plaintiffs' takings claims."293 The CFC denied that stay (a year and a half later) because the court agreed with plaintiffs that their claims asserted no "property" interest being determined in the state adjudication. ${ }^{294}$ They were instead asserting a "vested beneficial interest" in project water deliveries. ${ }^{295}$ The mysteries of this (non-)property interest would occupy federal and state courts for most of the next two decades. ${ }^{296}$ For this 'water war' ${ }^{297}$ was less about money than cultural supremacy. ${ }^{298}$

"Project water" would be "lost" downstream but for the federal investment, meaning the United States can and does put conditions on its delivery. ${ }^{299}$ The Bureau's terms had long expressly disclaimed liability for scarcities preventing delivery. ${ }^{300}$ So the contract, compact, and takings claims necessarily turned on fine distinctions. Under both California and Oregon law, an appropriative right to water is usufructuary: a

293. Klamath Irr. Dist. v. United States, 67 Fed. Cl. 504, 514 (Fed. Cl. Ct. 2005).

294. Id.

295. Id. This "vested beneficial interest" could well have becn grounded in federal law from a plausible interpretation of Ickes v. Fox, 300 U.S. 82, 94-95 (1937). See, e.g., Benson, supra notc 34 , at 385-86. Ironically, though, the cxclusion of state property/water law which becamc a condition on the CFC's adjudication of the plaintiffs' claims never did focus the court's attention on federal (common) law. See Baley, 134 Fed. Cl. at 641-43, 650-51; Klamath Irr. Dist., 67 Fed. Cl. at 514 .

296. See Klamath Irr. Dist. v. United States, 69 Fed. Cl. 160 (Ct. Fed. Cl. 2005); Klamath Irr. Dist. v. United States, 75 Fed. Cl. 677 (Ct. Fed. Cl. 2007); Klamath Irr. Dist. v. United States, 532 F.3d 1376 (Fed. Cir. 2008); Klamath Irr. Dist. v. United States, 227 P.3d 1145 (Or. 2010); Klamath Irr. Dist. v. United States, 635 F.3d 505 (Fed. Cir. 2011); Klamath Irr. Dist. v. United States, 129 Fed. Cl. 722 (Ct. Fed. Cl. 2016); Baley v. United States, 134 Fed. Cl. 619 (Ct. Fed. Cl. 2017).

297. See DOREMUS \& TARLOCK, supra note 279, at 11 (quoting a 2004 Washington Post editorial pronouncing that "[i]n the Klamath Basin, there is no middle road: Either the farmers move away, or the fish die.").

298. See id. at 195-97; ADLER, supra note 279, at 219-20; WILKINSON, supra note 34 , at 274-92. In 2000, irrigation accounted for 7.3 million of the Colorado River's 8.8 million acre-feet of appropriatcd water. $I d$. at 252 . With much of that going to irrigate feed crops like alfalfa, there is a great deal of room to improve the river's return-on-investment. Id. at 252-53.

299. See Israel v Morton, 549 F.2d 128, 132-33 (9th Cir. 1977). The federal storage project at Lake Mead, for example, has cnabled the State of Arizona to transfer tens of thousands of acrefeet of Colorado River water that it cannot currently use and "bank" it at various locations, mostly in aquifers, along its Central Arizona Project. See OWEN, supra note 51, at 140-45.

300 . The bulk of the terms and conditions in reclamation law structure how much real property irrigators may own, to whom they may sell, and for what purposes the water may be drawn from project-funded infrastructure. See Benson, supra note 34, at 410-16; cf. Ivanhoe Irr. Dist. v. McCracken, 357 U.S. 275, 294-300 (1958) (upholding Bureau of Reclamation's actions enforcing ownership limits and transfer restrictions). But expressly included in each of the contracts at issue in the Klamath were disclaimers about scarcity-induced withholdings (titled "United States Not Liable for Water Shortage"). See Gray, supra note 27, at 24. 
right not to the fluid itself but to the advantage of its use. ${ }^{301}$ And under the terms of the governing contracts from Upper Klamath Lake serving Oregon, deliveries were due unless scarcity "[o]n account of drought or other causes" prevented them. ${ }^{302}$ The CFC granted summary judgment to the Bureau on all but a handful of the contractual claims in $2005 .{ }^{303}$

On appeal, the (non-)property interest came under the microscope. The appeals court panel found a lack of "controlling precedent ... on the pertinent issues of Oregon property law"304 and certified several questions thereon to the Oregon Supreme Court. ${ }^{305}$ Among the questions: whether Oregon law vested a "beneficial or equitable property interest" in water delivered and put to beneficial use. ${ }^{306}$ It took the Oregon Supreme Court two years, but it created that interest-an interest never before declared by Oregon courts-out of relic precedents. ${ }^{307}$ As episodes in judicial federalism go, nothing was particularly amiss in that. ${ }^{308}$ The flaws were more subtle. Although the Oregon court pointed to two past instances where some entity held legal title to water rights in trust for others ${ }^{309}$ it had no version of the key to trustee duties: they must be

301. See Klamath Irr. Dist. v. United States, 67 Fed. Cl. 504, 515-16 (Fcd. Cl. Ct. 2005); cf. Joslin v. Marin Mun. Water Dist., 429 P.2d 889, 893-95 (Cal. 1967) (holding that California's dual system of water rights is subject to a general "reasonableness" requirement protecting the public interest and that scparation of sand and gravel is not a rcasonable use of water); Fort Vannoy Irr. Dist. v. Water Res. Comm'n, 188 P.3d 277, 298-99 (Or. 2008) (holding that Oregon water use certificates are and must be appurtenant to the land where the water is used).

302. $67 \mathrm{Fed}$. Cl. at 511 .

303. As to the irrigators' usufructuary interests, the court held that state law-by operation of Reclamation Act $\S 8-$ made the United States the appropriator, $67 \mathrm{Fed}$. Cl. at 523-26, and that any state law right to the water derived from the Burcau's deliveries would be subordinate to senior rights of tribes and other federal reservations. Id. at 538-39. It also held that nothing in the compact enhanced these rights, leaving them junior to the United States' claims. Id. at 539-40. That court later rejected the remaining contractual claims in Klamath Irr. Dist. v. United States, 75 Fed. Cl. 677 (Ct. Fed. Cl. 2007), and granted summary judgment to the United States. Id. at 677.

304. Klamath Irr. Dist. v. United States, 532 F.3d 1376, 1377 (Fed. Cir. 2008).

305. See id. at 1377-78.

306. Id. at 1378 .

307. It is telling that after having studied the question for almost two years and after having recently held that irrigation districts' interests in appropriative rights under Oregon law were merely in "trust" for irrigators, see Fort Vannoy, 188 P.3d at 295-96, the Oregon Supreme Court could find no governing precedent, no statute, and no other source to support the cxistence of this "equitable" (non-property) interest in project water and instead based its answer on Oregon cases where appropriative rights-holders had themselves created rights-holding entities, together with the construction of federal law from Nevada. See Klamath Irr. Dist. v. United States, 227 P.3d $1145,1162-66$ (Or. 2010).

308. Cf. Field, supra note 156, at 605-06 (defending certification of unresolved state law issues over the exercise of abstention discretion).

309. See Klamath Irr. Dist., 227 P.3d at 1161 (discussing In re Water Rights of Willow Creek, 236 P. 487 (Or. 1925); Eldredge v. Mill Ditch Co., 177 P. 939 (Or. 1919)). 
willingly assumed by a trustee in a deal making that trustee the beneficiary's fiduciary. ${ }^{310}$ A state court's equity jurisdiction could hardly put that duty on the Bureau or construe the United States' contracts to do so. ${ }^{311}$

Project water thought to be "lost" downstream 312 is like many other state jealousies that have long made the case for a federal forum. ${ }^{313}$ Should we have hoped for better from the Oregon court? ${ }^{314}$ In its return to federal court, this equitable interest in project water became the federal takings denominator the plaintiffs had sought. ${ }^{315}$ Vacating the CFC's dismissal, the Federal Circuit ordered further proceedings. ${ }^{316}$ A lone dissenter noted just how evasive the Oregon court had been about this equitable interest: for all that could be gleaned from its opinion, the creation of this relationship turned on the contractual terms between the United States and those putting the water to beneficial use. ${ }^{317}$ The certified questions had sought to unearth content from within Oregon law distinct from the federal contracts. ${ }^{318}$ For as the Claims Court had first observed,

310. John H. Langbein, The Contractarian Basis of the Law of Trusts, 105 YALE L.J. 625, 627 (1995). "Beneath the mechanics . . . lies the contractarian reality. . . The trustec must voluntarily accept the trusteeship...." Id. at 636 .

311. See Ivanhoe Irr. Dist. v. McCracken, 357 U.S. 275, 289 (1958); see also United States v. Winstar, 518 U.S. 839, 871-87 (1996) (Souter, J., plurality opinion) (enforccability of United States' contracts a matter of federal law); Bowen v. Pub. Agencies Opposed to Soc. Sec. Entrapment, 477 U.S. 41, 52 (1986) (holding that surrenders of sovereign authority through public contracts must, be in unmistakably clear terms).

312. See DOREMUS \& TARLOCK, supra note 279 , at 185.

313. See THE FEDERALIST NO. 80 , at 534 ("It scems scarcely to admit of controversy that the judiciary authority of the Union ought to extend . . . to all those [causes] in which the state tribunals cannot be supposed to be impartial and unbiassed.").

314. Cf. DAVID L. Shapiro, Federalism: A Dialogue 125 (1996) (observing that "states in our federal system serve not only as a countervailing force to federal power, but as an additional moderator of their own internal conflicts"); Hershkoff, supra note 208, at 1920-23 (offering a "public-values conception" of state judicial power wherein state courts seek to foster community development).

315. See Klamath Irr. Dist. v. United States, 635 F.3d 505, 511 -22 (Fed. Cir. 2011) [hereinafter Klamath $[I]$.

316. See id. at 522

317. See id. at 523-25 (Gajarsa, J., concurring). Tucker Act jurisdiction has posed riddles like this before. See, e.g., Preseault v. United States, 100 F.3d 1525, 1574-75 (Fcd. Cir. 1996) (en banc) (Clevenger, J., dissenting) (arguing that plurality opinion substituted its own view of underlying state law of casement termination after state judiciary refused answers to certified questions about easement). The construction of the United States' contractual obligations, however, would ordinarily involve the proprictary interests of the United States and, therefore, the federal common law thereof. See Clark, supra note 11, at 1361-75; Field, supra note 87, at 909-11, 953-58.

318. The closest thing to a denominator in the Oregon Supreme Court's answer was its discussion of Nevada-which, for its part, had invoked Ickes, California, and Nebraska v. Wyoming, 325 U.S. 589 (1937). However, none of those precedents construing the Bureau's Reclamation Act $\S 8$ role ever referred to anything other than a state law "property" interest derived from pro- 
the Reclamation Act itself does not vest any right to project water in anyone - be it an end user, irrigation district, or other - because it refers throughout to water rights "otherwise acquired." 319 The Oregon court's heavy reliance on Nevada $v$. United States ${ }^{320}$ construing the Reclamation Act's interface with Nevada law was, thus, misguided at best. ${ }^{321}$

But the CFC obliged on remand and heard arguments on whether the Bureau's water withholdings amounted to a "physical" taking thereof. ${ }^{322}$ This physical taking theory promised to route plaintiffs' claims around the factor balancing that has so frustrated Penn Central claimants. ${ }^{323}$ The trouble with this theory was that water rights, whatever their value, are never a claim on the fluid itself. A water right is not the right to pos-

ject water delivered and put to beneficial use. See Nevada v. United States, 463 U.S. 110, 121-28 (1983).

319. See Klamath Irr. Dist., 67 Fed. Cl. at 516-23 (discussing Ickes v. Fox, 300 U.S. 82 (1937), and California v. United States, 438 U.S. 645 (1978), and their combined effect of leaving project water customers to the state law of appropriations for any water rights they might acquire).

320. See Klamath Irr. Dist., 227 P.3d at 1162-66. The Oregon court never let on that an "equitable" interest apart from state water rights law could only be properly adjudicated in an Oregon forum - the only authority with the state judiciary's cquitable powers. See Sanchez-Llamas v. Oregon, 548 U.S. $331,345-48$ (2006) (holding that federal courts are without authority to impose suppression of evidence remedy in state court's adjudication of state's alleged violation of Vienna Convention on Consular Relations); Sea River Props., LLC v. Parks, 333 P.3d 295, 306-09 (Or. 2014).

321. Oddly, the Oregon court stated that it found Nevada's "analysis both persuasive and consistent with Oregon law." Klamath Irr. Dist., 227 P.3d at 1163 (cmphasis added). But the Supreme Court's holding in Nevada was that Nevada law vested a water right in those putting project water to beneficial use. See Nevada, 463 U.S. at 126-28.

322. See Klamath Irr. v. United States, 129 Fcd. Cl. 722, 731-37 (Ct. Fed. Cl. 2016). The theory that a temporary withholding of water deliveries from government-owned infrastructure was a "physical" (or "per se") taking avoiding Penn Central balancing had briefly convinced a Federal Circuit pancl in a similar case, Casitas Municipal Water District v. United States, 543 F.3d 1276 (Fed. Cir. 2008). That court had concluded, for purposes of denying summary judgment whercin the government had conceded the existence of state law property interests in the water delivery, that a diversion of water to a government-mandated fish ladder could be a "physical" requisitioning of water to which the plaintiffs were entitled. Id. at 1292. Fivc years later-but before the CFC's decision and remand in Klamath $I I-$-a different panel reversed course, holding that the government's concessions for purposes of summary judgment were pivotal, that a California water right to "beneficial use" of delivered water could not support a physical takings claim, and that if any takings claim did accruc it would only be because the diverted water so diminished the supply that the plaintiffs' bencficial use was precluded. See Casitas Mun. Water Dist. v. United States, 708 F.3d 1340, 1353-59 (Fed. Cir. 2013).

323. Penn Central balances have rarely tilted in a claimant's favor, no doubt explaining the rise of arguments (in water rights cases and elsewhere) that a taking is a physical requisitioning of the property at issue and is therefore per se compensable. See Tulare Lake Basin Water Storage Dist. v. United States, 49 Fcd. Cl. 313, 319 (Fed. Cl. 2001) (citing Int'l Papcr Co. v. United States, 282 U.S. 399 (1931)); see also Casitas Mun. Water Dist. v. United States, 708 F.3d 1340, 1352-53 (Fed. Cir. 2013); CRV Enters., Inc. v. United States, 626 F.3d 1241 (Fed. Cir. 2010); Washoe Cty. v. United States, 319 F.3d 1320 (Fed. Cir. 2003); Estate of Hage v. United States, 82 Fed. Cl. 202 (Ct. Fed. Cl. 2008), rev'd, Estate of Hage v. United States, 687 F.3d 1281 (Fcd. Cir. 2012). 
sess anything. ${ }^{324}$ It is an advantage of use: vested, delineated, exercised, and transferred by its means of use. ${ }^{325}$ Fluid water, after all, is intangible given its phase instability, incipient loss to vegetation, precipitation, and gravity. Appropriative rights are thus unusual property interests: even in elemental form they vest powers in others over one's interests. ${ }^{326}$ Such rights resemble the interests owners have in a debt or in money-a claim to some part of the wherewithal of another. ${ }^{327}$

Nonetheless, the CFC - by the third judge to preside in the cases, Judge Marian Blank Horn-held that "binding precedent" in the Federal Circuit forced the conclusion that a failure to deliver project water should be judged in the physical takings rubric. ${ }^{328}$ The irony, though, came following Judge Horn's trial of the surviving claims in the Klamath; a trial focused on discrete contractual duties that also finally confronted the tribal rights in the basin. ${ }^{329}$ After parsing the relevant con-

324. See Benson, supra note 34 , at $375-76$ (citing HUTCHINS, supra note 63, at 140-41; Frank J. Trelease, Government Ownership and Trusteeship of Water, 45 CAL. L. REV. 638 (1957)); cf. Fort Vannoy Irr. Dist. v. Water Res. Comm'n, 188 P.3d 277, 296-98 (Or. 2008) (interpreting Oregon statute's "holder of any water use subject to transfer" to encompass only that water put to beneficial use).

325. See Taiawagi Hclton \& Rhett Larson, Elements of Prior Appropriation, in WATERS AND WATER RIGHTS at $\S 12.02$ (c)(2) (3d ed. 2017). The courts' repeated citations to International Paper Co. v. United States, 282 U.S. 399 (1931), a case of the Sccretary of War's bringing of eminent domain proceedings to requisition a water power and canal site on the Niagara River, id. at 404-06, was, thus, jurisdictionally naïve to say the least.

326. Senior appropriative rights-holders generally may not change uses if it prejudices other appropriators. See Farmers Highline Canal v. Golden, 272 P.2d 629 (Colo. 1954). This 'no injury' rule has long entrenched implicit restrictions on appropriative rights. See HuTCHINS, supra note 63 , at 649-50 (noting principles applicable to changes of use and the gencral rule that changes harming other appropriators are generally disfavored); Mark Squillace, The Water Marketing Solution, 42 ENVTL. L. RPTR. 10800, 10804 (2012) (observing that the "[ $t$ ]he real obstacle to the [transferability] of water rights seems to be the uncertainty that the no injury rule brings to the transfer"); NAT'L RESEARCH COUNCIL, WATER TRANSFERS IN THE WEST: EFFICIENCY, EQUITY, AND THE ENV'T 38-67 (1992).

327. Penner describes property in debts as such. See PENNER, supra note 141, at 129-31. On the property interests in money, see DAVID FOX, PROPERTY RIGHTS IN MONEY (2008). Notably, the legal regime supporting money also tends "to ensure that the person with the possession of the money or the practical power to spend it also has the best legal and beneficial title to it." Id. at 49. This may explain the interests in project water, as well. See infra note 491 and accompanying text.

328. Klamath Irr, $129 \mathrm{Fed}$. Cl. at $732-36$ (citing Casitas, $543 \mathrm{~F} .3 \mathrm{~d}$ 1276). Judge Horn in turn denied the government's motion in limine and granted plaintiffs' cross-motion, agreeing that the claims "should be analyzed under the physical takings rubric"' at trial. Id. at 737. After trial, Judge Horn reaffirmed the conclusion. See Baley v. United States, 134 Fed. C1. 619, 663-64 (Ct. Fed. Cl. 2017). But it remains unclear how a non-possessory equitable interest could suffer the sort of physical intrusion which the Supreme Court has said is the prerequisite to this branch of takings liability. Cf. CRV Enters., 626 F.3d at 1243-48 (Fed. Cir. 2010) (rejecting physical takings theory in case involving government's exclusion of riparian owner from navigable water on grounds that no physical intrusion upon riparian's property had been imposed).

329. See Baley, 134 Fcd. Cl. at 644-45. 
tracts, ${ }^{330}$ Judge Horn determined that none of the interests ostensibly created thereby had been taken or impaired because the United States' fulfillment of its treaty obligations starting in 2001-protecting the imperiled species of the Klamath River-served water rights senior to the claimants. ${ }^{331}$ In short, the instream flows fulfilled the most senior priorities on the river. ${ }^{332}$ Given the "fundamental principle of water law in prior appropriation states that a senior water right 'may be fulfilled entirely before ... junior appropriators get any water at all," ${ }^{333}$ no taking could logically have occurred. ${ }^{334}$

The claims' circularity was finally revealed. A federal forum examined every possible basis and found no colorable takings claim. But most claims never go that distance. Ripeness and finality doctrines have often idled water takings litigation in the CFC, a fate that may be rarer after Knick v. Township of Scott. ${ }^{335}$ And Judge Horn's forcing the issue of tribal treaty rights despite their never having been quantified predated the Supreme Court's 2017 Murr opinion-which may now offer still more options for a water-right takings claimant. ${ }^{336}$ Litigating these

330. Id. at $627-33,652-59$.

331. See id. at 670-80. "The court . . . concluded that the Tribes' water right entitled them to keep at least as much water in Upper Klamath Lake and the Klamath River as was necessary to prevent jeopardizing the continued existence of the [imperiled fish species]" based on the biological opinions produced by the wildlife agencies. Id. at 673 .

332. Judge Horn's conclusion to this effect was most noteworthy since the tribes' basic priority had not yet been assigned a date-due at lcast in part to Colorado River abstention-nor had it been quantified. See Baley, $134 \mathrm{Fed}$. Cl. at 668-72. The judge drew the legal conclusion that the date was carly enough and the amount great enough "to keep at least as much watcr in Upper Klamath Lake and the Klamath River as was necessary to prevent jeopardizing" the listed species of fish, as the agencies had thought was required by the Endangered Specics Act. Id. at 673. The Federal Circuit affirmed. See Balcy v. United States, 2019 WL 5995861 (Fcd. Cir. 2019).

333. Baley, $134 \mathrm{Fcd}$. Cl. at 678 (quoting Montana v. Wyoming, 536 U.S. 368, 376 (2011)).

334. Although the court suggested that the tribes' treaty rights "hold a priority date of 'time immemorial," id. at 670 (quoting United States v. Adair, 723 F.2d 1394, 1414 (9th Cir. 1983)), it denied the claims being litigated by assuming without deciding that 1891 - the date of the last executive order establishing the rescrvations-marked their priority dates. See id. at 670-71 (finding that plaintiffs' carliest possible priority dates must all be at least ten years junior to tribes' latest possible priority dates); See also Klamath Water Users Protect. Ass'n v. Patterson, 204 F.3d 1206, 1213-14 (9th Cir. 2000) (affirming district court judgment that Burcau was authorized to divert water at Link River Dam to fulfill tribal water rights because tribes' rights "carry a priority date of time immemorial") (quoting Adair, 723 F.2d at 1414).

335. Knick v. Township of Scott, 139 S. Ct. 2162,2179 (2019) (overruling Williamson Cty. Reg'l Planning Comm'n v. Hamilton Bank, 473 U.S. 172 (1985), and holding that $\$ 1983$ claims of takings may be litigated in federal court if alleged act of taking has already occurred). This will undoubtedly shift the jurisdictional picture in water takings cascs, as well. See, e.g., Casitas, 708 F.3d at 1358-60; Estate of Hage, 687 Fed. Cir. at 1287.

336. See supra notes 262-68 and accompanying text. 
claims is treacherous and costly work, ${ }^{337}$ likely more so now after Murr. ${ }^{338}$ But ping-ponging between state and federal forums-which once had seemed a remote and dystopic prospect ${ }^{339}$ - may well become the norm given the jurisdictional posture of so many water rights, the overcommitment of "project water" throughout the West, and the crisscross of jurisdictional lanes for declaring the applicable law. If litigation costs are not prohibitive, intensifying drought and scarcities will almost surely push that edge. And it is one where, again, the jurisdictional confusions will only deepen.

\section{DEFINING "WATERS": A DELEGATION TO WhOM?}

When Congress set aside a jurisdictional term found throughout its momentous water pollution amendments in 1972,340 it declared "navigable waters" included all "waters of the United States, including the territorial seas."34I Decades of fractured authority to interpret the statute have since left landowners to sift through mountains of disparate judicial and administrative declarations. ${ }^{342}$ Mistakes can be penalized severely, ${ }^{343}$ posing hard questions about the force of administrative rules. ${ }^{344}$ (A

337. See Gray, supra note 27 , at 26.

338. In applying Murr, it is unclear whether the water rights law of the situs statc should exhaust the Murr factor for "state or local law" or rather whether prior appropriation more generally should. Cf. Reed D. Benson, Maintaining the Status Quo: Protecting Established Water Uses in the Pacific Northwest, Despite the Rules of Prior Appropriation, 28 ENVTL. L. 881 (1998) (finding that the most consistent commonality of water rights law throughout the Pacific Northwest has been protecting the status quo).

339. See Williamson B.C. Chang, Missing the Boat: The Ninth Circuit, Hawailan Water Rights and the Constitutionality of Retroactive Overruling, 16 GOLDEN GATE U. L. REV. 123, 128-35 (1986) (discussing the McBryde Sugar litigation and characterizing it as an outlier born of extreme litigiousness and willful judges).

340. The Federal Water Pollution Control Act Amendments of 1972, Pub. L. No. 92-500, 86 Stat. 816 (1972), were designated the "Clean Water Act" in 1977. See Pub. L. No. 95-217, \& 2, 91 Stat. 1566, 1566 (1977).

341. See 33 U.S.C. $\S 1362(7)(2012)$.

342. United States v. Hawkes Co., 136 S. Ct. 1807, 1812 (2016).

343. See Hawkes, $136 \mathrm{~S}$. Ct. at 1812 ("It is often difficult to determine whether a particular parcel of property contains waters of the United States, but there are important consequences if it docs."). Writing separately in Sackett v. EPA, Justice Alito made special note that if "owners do not do the EPA's bidding [given the presence of jurisdictional waters], they may be fined up to $\$ 75,000$ per day." Sackett v. EPA, 566 U.S. 120, 132 (2012) (Alito, J., concurring).

344. Administrative rules' place in federal supremacy has never been assured. See Wayman v. Southard, 23 U.S. (10 Wheat.) 1, 43-46 (1825) ("The line has not been exactly drawn which separates those important subjects, which must be cntirely regulated by the legislature itself, from those of less interest, in which a general provision may be made, and power given to those who are to act under such general provisions."). Although the Court still adheres to the fiction that Congress may not delegate "legislative Power," see Whitman v. Am. Trucking Ass'ns, 531 U.S. 
mature literature about that force evidences little consensus. ${ }^{345}$ ) But this horizontal struggle over Congress's delegation bears uncanny resemblance to the vertical jurisdictional muddles of Parts II and III. Section A describes the Act's joint administration by the Corps of Engineers and EPA in competition with the judiciary while Section B examines the role of provable facts within that competition.

\section{A. Judicial or Administrative Authority?}

Federal and state systems have long been adapting the concept of navigable waters. ${ }^{346}$ When the Supreme Court broke federal admiralty jurisdiction away from Westminster's traditions in the mid-nineteenth century, it turned to navigation and navigability. ${ }^{347}$ It also linked Congress's commerce power to navigation and navigability. ${ }^{348}$ When the

457, 487-88 (2001) (Stevens, J., concurring), that itself may portend other changes. See, e.g., Heather Elliott; Justice Gorsuch's Would-Be War on Chevron, 21 GREENBAG (2d) 315 (2018).

345. See Kathryn A. Watts, Rulemaking as Legislating, 103 GEO. L.J. 1003 (2015); Kristin E. Hickman, Unpacking the Force of Law, 66 VAND. L. REV. 465 (2013); Jacob E. Gersen, Legislative Rules Revisited, 74 U. CHI. L. REV. 1705 (2007); John F. Manning, Nonlegislative Rules, 72 GeO. WASH. L. REV. 893 (2004); Thomas W. Merrill \& Katherine Tongue Watts, Agency Rules with the Force of Law: The Original Convention, 116 HARV. L. REV. 467 (2002); William Funk, When is a "Rule" a Regulation?: Marking a Clear Line Between Nonlegislative Rules and Legislative Rules, 54 ADMIN. L. REV. 659 (2002); Thomas W. Merrill \& Kristin E. Hickman, Chevron's Domain, 103 GEO. L.J. 833 (2001); Paul R. Verkuil, Judicial Review of Informal Rulemaking: Waiting for Vermont Yankec II, 55 TUL. L. REV. 418 (1981); Glenn O. Robinson, The Making of Administrative Policy: Another Look at Rulemaking and Adjudication in Administrative Procedure Reform, 118 U. PA. L. REV. 485 (1970).

346. See ROBERTSON supra note 85, at 104-22; Danicl J. Hulscbosch, Writs to Rights: "Navigability" and the Transformation of the Common Law in the Nineteenth Century, 23 CARDOzO L. REV. 1049 (2002); Robert W. Adler, The Ancient Mariner of Constitutional Law: The Historical, Yet Declining Role of Navigability, 90 WASH. U. L. REV. 1643 (2013); Maureen E. Brady, Defining "Navigability": Balancing State-Court Flexibility and Private Rights in Waterways, 36 CARDOZO L. REV. 1415 (2015). Navigable rivers played a unique role in European imperialism. See LAUREN BENTON, A SEARCH FOR SOVEREIGNTY: LAW AND GEOGRAPHY IN EUROPEAN EMPIRES, 1400-1900 (2010).

347. See The Propeller Gcnesce Chicf v. Fitzhugh, 53 U.S. (12 How.) 443, 458-59 (1851) (overruling 'cbb and flow of the tide' test articulated in The Thomas Jefferson, 23 U.S. (10 Wheat.) 428 (1825), embracing a 'navigated-in-fact' test for admiralty jurisdiction); The Magnolia, 61 U.S. (20 How.) 296, 301 (1857) (holding that "navigable" river, regardless of tidal influence, was within admiralty jurisdiction); The Eagle, 75 U.S. (8 Wall.) 15, 24 (1868) (interpreting Genesee Chief to extend jurisdiction under the first Judiciary Act to all waters where navigation was possible); The Steamer Montello, 87 U.S. (20 Wall.) 430 (1874) (describing the use of canoes carrying goods); The Robert W. Parsons, 191 U.S. 17, 29-34 (1903) (finding that the Erie Canal was "navigable water" subject to admiralty jurisdiction).

348. See, e.g., The Daniel Ball, 77 U.S. (10 Wall.) 557 (1870) (extending Commerce Clause authority to all waters used or susceptible to use in interstate or foreign commercc); United States v. Rio Grande Dam \& Irr. Co., 174 U.S. 690 (1899) (upholding assertion of federal authority over non-navigable reach of navigable-in-fact river); United States v. Appalachian Elec. Power Co., 
federal common law vesting states with sovereign title to navigable waters hardened, it made still another use of the concept. ${ }^{349}$ And as has been chronicled repeatedly, with so many legal relations turning on navigability, elasticity became the norm. ${ }^{350}$ By 1972 , it was a venerable-if varied-jurisdictional boundary. A conference committee report cast the 1972 definitional step as a congressional choice to assert federal authority to the limits of Article I and it influenced several early judicial interpretations. ${ }^{351}$ The text of the statute, though, declared no such thing ${ }^{352}$ and getting the Corps to commit to such jurisdiction took a court order sought by citizen-plaintiffs. ${ }^{353}$ The ambiguity was apparently pivotal to the Act's passage through Congress. ${ }^{354}$ By the end of the decade, though, both agencies were asserting CWA authority over much more

311 U.S. 377 (1940) (upholding assertion of federal authority over waters susceptible to navigation with reasonable improvements, even for purposes besides enhancing navigation).

349. See Shively v. Bowlby, 152 U.S. 1, 26-28 (1894); United States v. Oregon, 295 U.S. 1 (1935); Utah v. United States, 403 U.S. 9, 10 (1971); PPL Montana, 132 S. Ct. at 1226-28.

350. See ROBERTSON supra note 85 , at 104-22; Hulsebosch, supra note 346, at 1090-1105; Adler, supra note 346, at 1651-69; Brady, supra note 346, at 1421-33.

351. See United States v. Ashland Oil \& Transp. Co., 504 F.2d 1317, 1323-24 (6th Cir. 1974); United States v. Holland, 373 F. Supp. 665, 668-73 (M.D. Fla. 1974); see also Sam Kalen, Commerce to Conservation: The Call for a National Water Policy and the Evolution of Federal Jurisdiction Over Wetlands, 69 N.D. L. REV. 873, 891-94 (1993) (discussing Holland's use of the committee report and the agencies' subsequent turn toward expanding CWA jurisdiction in line with the committee statement). The Federal Water Pollution Control Act of 1948 applied only to "interstate" waters, a jurisdictional scope Congress retained across multiple amendments-until 1972. See N. William Hines, History of the 1972 Clean Water Act: The Story Behind How the 1972 Act Became the Capstone on a Decade of Extraordinary Environmental Reform, 6 GEO. WASH. J. ENERGY \& ENVTL. L. 80, 98-99 (2013). Notably, though, the Rivers and Harbors Appropriation Act of 1899 had prohibited covered discharges to "any navigable water of the United States, or into any tributary of any navigable water. ..." Kalur v. Resor, 335 F. Supp. 1, 9 (D.D.C. 1971) (quoting Act of Mar. 3, 1899, ch. 425, § 13, 30 Stat. 1152 (1899), codificd at 33 U.S.C. $\S 407)$.

352. See Solid Waste Agency of N. Cook Cty. v. United States, 531 U.S. 159, 172-74 (2001).

353. See Kalen, supra note 351, at 892-93 (discussing Nat'l Res. Def. Council v. Callaway, 392 F. Supp. 685 (D.D.C. 1975), and the court's decrec ordering the Corps of Engineers to amend its nules to assert jurisdiction under the CWA in keeping with Congress's decision). The Act's citizen suit provision, CWA $\S 505$ (a), predating as it did the repeal of the amount-in-controversy requirement from 28 U.S.C. $\$ 1331$ (a) and the waiver of sovereign immunity for all APA actions in 1976 , blazed a novel path into federal court leading to that decree. See Gwaltney of Smithfield $\checkmark$. Chesapeake Bay Found., 484 U.S. 49, 52-54 (1987) (discussing the jurisdictional grant and cause of action provided by 33 U.S.C. $\$ 1365(a)$ ). But by 1976, federal question jurisdiction was broadened considerably. See Califano v. Sanders, 430 U.S. 99, 104-09 (1977) (discussing amendments' effects on federal question jurisdiction).

354. See Hines, supra note 351 , at 104 . Courts and commentators often disparage Congress for its strategic uses of ambiguity, but it is far from clear that Congress has much choice in the matter. See KREHBIEL, supra note 14, at 230; VICTORIA NOURSE, MISREADING LAW, MISREADING DEMOCRACY 25-33, 99-101 (2016). 
territory than just "navigable-in-fact" waterways. ${ }^{355}$ The question had become whether the courts would foster or fetter that effort.

The Act's purpose was "the restoration and maintenance of the chemical, physical, and biological integrity of the nation's waters," 356 a purpose that could not be served by ignoring waters' connections to watersheds or trends like overuse, urbanization, eutrophication, species loss, etc. ${ }^{357}$ The Corps had first consolidated four categories of $\S 502(7)$ "waters" by regulation in $1977 .{ }^{358}$ (EPA had done so to varying degrees of formality since $1973 .{ }^{359}$ ) The categories were (1) navigable-in-fact streams, rivers, lakes, coastal waters, and the wetlands "adjacent" thereto; (2) tributaries of (1); (3) "interstate" streams, rivers, lakes, and their tributaries and adjacent wetlands; and (4) all "other waters" "the degradation or destruction of which could affect interstate commerce." $" 360$ Categories (1)-(3) by then had all appeared in some judicial precedent construing jurisdictional waters, i.e., had had their federal interest declared by an Article III court. ${ }^{361}$ Interstate waters had long been the subject of the Supreme Court's original jurisdiction. ${ }^{362}$ Tributaries had often fea-

355. This cvolution has been ably described elsewhere. See Kalen, supra note 351 , at 87997; Jonathan H. Adlcr, Wetlands, Waterfowl, and the Menace of Mr. Wilson: Commerce Clause Jurisprudence and the Limits of Federal Wetland Regulation, 29 ENVTL. L. REV. 1 (1999).

356. Pub. L. No. 92-500, § 101(a), 86 Stat. 816, 816 (1972), codified at 33 U.S.C. $\$ 1251$ (a).

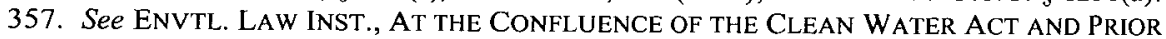
APPROPRIATION 6-12 (2013); Jamison E. Colburn, Coercing Collaboration: The Chesapeake Bay Experience, 40 WM. \& MARY ENVTL. L. \& POL'Y REV. 677, 698-704 (2106).

358. See U.S. Army Corps of Eng'rs, Final Rulc-Regulatory Programs of the Corps of Eng'rs, 42 Fed. Reg. 37,122, 37,127-28 (1977). Two interim final rules preceded the 1977 rulemaking but had not yet consolidated their terms as did the 1977 rcgulations. See id. at 37,127.

359. EPA's 1980 consolidated permitting rules first brought together the same four categories as the Corps, although a multitude of administrative rules had previously asserted the expansive interpretations of "waters." See U.S. EPA, Final Rule - Consolidated Pcrmitting Rulcs, 45 Fed. Reg. 33,290 (1980), and were reorganized in 1983 to take the form litigated in the seminal cases. See U.S. EPA, Final Rulc-Environmental Permit Regulations, 48 Fed. Reg. 14,146, $14,157(1983)$.

360. 42 Fed. Reg. at 37127.

361. The terse explanation of the 1977 list declarcd an intent to track what prior federal precedents had adjudicated was within jurisdictional reach. See 42 Fed. Reg. at 37127-30 (discussing United States v. Ashland Oil and Transportation, 504 F.2d 1317 (6th Cir. 1974) and Natural Resources Defense Council. v. Train, 366 F. Supp. 1393 (D.D.C. 1975)). Key to the 1977 rules were the addition of wetlands (upland of mean high-water) and small tributaries of navigable-infact waters. See Kalen, supra notc 351 , at 897-906.

362. See supra note 103 and accompanying text. The Trump Administration rule aims to climinate interstate waters from $\S 502(7)$. See Dept. of Defense, Environmental Prot. Agcncy, Proposed Rule--Revised Definition of "Waters of the United States, 84 Fed. Reg. 4154, 4171-72 (2019). 
tured in litigation of navigable waters' limits. ${ }^{363}$ Navigated-in-fact waters, i.e., used for transport, had been included in states' public trust at least since $1971 .^{364}$ A normalized mean high tide line as a water's lateral limit dates from at least $1935 .{ }^{365}$ The addition of adjacent wetlands to CWA jurisdiction had grown from litigation of the Rivers and Harbors acts' lateral limits in the lead up to $1972 .{ }^{366}$ Finally, category (4) waters stemmed from the Supreme Court's 'nexus to commerce' precedents on Article I's limits. ${ }^{367}$

But jurisdiction over non-navigable tributaries and connected wetlands was immediately contentious. ${ }^{368}$ The Corps itself was unsure how far laterally or upstream its permitting authority should reach. ${ }^{369}$ An agency turf battle settled in $1979^{370}$ bound the Corps to EPA's interpretations of $\S 502(7)$ and focused the attention on target areas' legal ties to commerce. ${ }^{371}$ A case-by-case approach expanded the Act's jurisdictional

363. See United States v. Rio Grande Dam \& Irr. Co., 174 U.S. 690 (1899); Economy Light \& Power Co. v. United States, 256 U.S. 113 (1921); Oklahoma ex rel. Phillips v. Guy F. Atkinson Co., 313 U.S. 508 (1941); United States v. Grande River Dam Auth., 363 U.S. 229 (1960); United States v. Underwood, 344 F. Supp. 486 (M.D. Fla. 1972); United States v. Ashland Oil \& Transp. Co., 504 F.2d 1317 (6th Cir. 1974); United States v. Phelps Dodge Corp., 391 F. Supp. 1181 (D. Ariz. 1975).

364. See Utah v. United States, 403 U.S. 9, 11-13 (1971).

365. See Borax Consol., Ltd. v. Los Angeles, 296 U.S. 10, 24-27 (1935); see also Leslie Salt Co. v. Frochlkc, 403 F. Supp. 1292, 1297 (N.D. Cal. 1974).

366. See United States v. Stoeco Homes, Inc., 498 F.2d 597, 602-07 (1974); United States v. Holland, 373 F. Supp. 665, 676 (M.D. Fla. 1974); Zabel v. Tabb, 430 F.2d 199, 201-03, 207-11 (5th Cir. 1970).

367. See 42 Fed. Reg. at 37124; id. at 37127 (citing Perez v. United States, 402 U.S. 146 (1970); Katzenbach v. McClung, 379 U.S. 294 (1974); Heart of Atlanta Motel, Inc. v. United States, 379 U.S. 241 (1964); Wickard v. Filburn, 317 U.S. 111 (1942)).

368. See Kalen, supra note 351, at 905-13; Colburn, supra note 39 , at 88-93. The first precedent on tributaries of navigable-in-fact waters under $\$ 502(7)$, Ashland Oil, 504 F.2d 1317, invoked but then distinguished federal common law's 'navigational servitude' and declared that it would "make a mockery of those powers if [Congress's] authority to control pollution was limited to the bed of the navigable stream itself." Id. at 1326. "The tributaries which join to form the river," the court continued, "could then be used as open sewers as far as federal regulation was concerned. The navigable part of the river could become a mere conduit for upstream wastc." $I d$. at 1326-27 (quoting Oklahoma ex rel. Phillips v. Atkinson Co., 313 U.S. 508 (1941)).

369. See Colburn, supra note 39; at 109-10 \& n.198.

370. EPA was declared to be the "ultimate administrative authority [in construing] the jurisdictional term "navigable waters"' in their shared programs under CWA $\S 404$. See Benjamin R. Civiletti, Administrative Authority to Construe $\$ 404$ of the Federal Water Pollution Control Act, 43 OP. ATT'NY GEN. 197 (1979).

371. See Elaine Bueschen, Do Isolated Wetlands Substantially Affect Interstate Commerce? 46 AM. U. L. REV. 931, 936-43 (1997); Daryn McBeth, Wetlands Conservation and Federal Regulation: An Analysis of the Food Security Act's Swampbuster Provisions as Amended by the Federal Agriculture Improvement and Reform Act of 1996, 21 HARV. ENVTL. L. REV. 201, 222-46 (1997). EPA's focus on this nexus remained tacit in its 1980 consolidated permitting rules. See U.S. Environmental Protection Agency, Consolidated Permit Regulations, 45 Fed. Reg. 33290 
scope as the precedents mounted. ${ }^{372}$ Supreme Court precedents confirming the Commerce Clause's elasticity were vital. ${ }^{373}$ But given the gradient waters comprise, controversy over the delegation's scope eventually came to overshadow most other issues. ${ }^{374}$

Reversing the Sixth Circuit, the Supreme Court held in United States v. Riverside Bayview Homes ${ }^{375}$ that connected wetlands could be "waters" within $\S 502(7)$, declaring that jurisdiction originated from and turned upon the wetlands' ecological influence on the traditional "water." ${ }^{376}$ In sustaining the agencies' extension of CWA jurisdiction "to all wetlands adjacent to navigable or interstate waters and their tributaries," 377 the Court declared that "Congress evidently intended to repudiate limits that had been placed on federal regulation by earlier water pollution control statutes and to exercise its powers under the Commerce Clause to regulate at least some waters that would not be deemed "navigable" under the classical understanding of that term." ${ }^{378}$ Noting that bills to constrain the agencies had all stalled in Congress, ${ }^{379}$ the River-

(1980). By 1988, its focus on the commerce nexus had firmed considerably. See U.S. Environmental Protection Agency, Final Rulc-Clcan Water Act Scction 404 Program Definitions and 'Permit Exemptions, 53 Fed. Reg. 20764, 20765 (1988) (citing United States v. Riverside Bayview Homes, Inc., 474 U.S. 121 (1985)).

372. EPA's first CWA $\S 404$ (b) "guidelincs" cited United States v. Byrd, 609 F.2d 1204 (7th Cir. 1979), and Leslie Salt Co. v. Froehlke, 578 F.2d 742 (9th Cir. 1978). See U.S. EPA, Guidelines for Spccification of Disposal Sites for Dredged or Fill Material, 45 Fed. Reg. 85336, 85340 (1980). Each case involved extensive expert testimony surrounding the target area and its individual ncxus to commerce. See Byrd, 609 F.2d at 1207-09; Leslie Salt, 578 F.2d at 745-47.

373. As I have shown before, the earliest CWA jurisdictional challenges in the 1970 s and ' 80 s played out in the shadow of United States v. Appalachian Elec. Power Co., 311 U.S. 377 (1940). That Court held that if cost-effective improvements could render a water navigable-infact, Congress's Article I, $\S 8$ powers extended to that water. See id. at 407-08; Colburn, supra note 39 , at $95 \&$ n. 116 .

374. See Kalen, supra notc 351, at 909-13; Adler, supra note 355, at 19-30; Colburn, Governing the Gradient, supra notc 39, at 111-15.

375. 474 U.S. 121 (1985).

376. Cf. id. at 134-35 (noting that the agencies had concluded adjacent wetlands "may function as integral parts of the aquatic cnvironment" and that that conclusion was one to which the courts should defer). The Sixth Circuit had held that wetlands could not be "waters" and that if that were Congress's intent, it effectuated a taking of the defendant's property. See United States v. Riverside Bayvicw Homes, Inc., 729 F.2d 391, $397-98$ (6th Cir. 1984) (citing Kaiscr Aetna v. United States, 444 U.S. 164 (1979)).

377. Riverside, 474 U.S. at 129.

378. Id. at 133 (citing S. CONF. REP. No. 92-1236, p. 144 (1972)). The oft-repeated Conference Report statement was that "[ $t]$ he conferees fully intend that the term "navigable waters" be given the broadest possible constitutional interpretation unencumbered by agency determinations which have been made or may be made for administrative purposes." S. REP. No. 92-1236, 92d Cong., 2d Sess., at 144, reprinted in 1972 U.S. Code Cong. \& Admin. News at 3822.

379. See Riverside, 474 U.S. at 135-39. 
side Court found that the CWA was a delegation to the agencies. ${ }^{380}$ And with that endorsement, rulemakings in $1986^{381}$ and $1988,{ }^{382}$ flanked by guidance pressing the nexus-to-commerce linkage, ${ }^{383}$ focused reviewing courts on the precise scope of the delegation. ${ }^{384}$

In Solid Waste Agency of North Cook County v. United States ${ }^{385}$ and Rapanos v. United States ${ }^{386}$ the Court reconsidered its Riverside holding. Where Solid Waste declared that jurisdiction over small, geographically "isolated" waters went beyond the delegation, ${ }^{387}$ the Rapanos Court seemed to cloud all assertions of jurisdiction over non-navigable tributaries or adjacent wetlands in a fractious, muddled interpretation of the law. ${ }^{388}$ Without a hint of irony, ${ }^{389}$ the Chief Justice separately scold-

380. See id., 474 U.S. at 134 (holding that the agencies' interpretation could not be set aside unless it was "unreasonable" within the mcaning of Chevron U.S.A., Inc. v. Natural Resources Defense Council, Inc., 467 U.S. 837 (1984)). Riverside's apparent theory of delegation was Chevron's "delegation-by-ambiguity" argument Justice Stevens' opinion had brought to prominence. See Merrill \& Hickman, supra note 345 , at 838-39, 870-72.

381. See U.S. Army Corps of Eng'rs, Final Rule for Regulatory Programs of the Corps of Engineers, 51 Fed. Reg. 41206 (1986).

382. See U.S. Envtl. Prot. Agency, Final Rulc-Clean Water Act Section 404 Program Definitions and Permit Exemptions, 53 Fed. Reg. 20764 (1988).

383. See 51 Fed. Reg. at $41216-17 ; 53$ Fed. Reg. at 20765. These rulemakings-in the wake of Riverside and following ycars of White House involvement through its 'Task Force on Regulatory Review'- signaled each agency's full intention to assert jurisdiction on a "case-by-case basis" over waters bearing some provable nexus to interstate commerce. See Kalen, supra note 351, at $905-06 \&$ n. 172 .

384. At least one district court held that, before migratory bird use could serve as the connection between a target site and navigable waters, the agencies would need a rulemaking to that effect. See Tabb Lakes, LTD v. United States, 715 F. Supp. 726 (E.D. Va. 1988), aff'd, 885 F.2d 866 (4th Cir. 1989). The Eighth Circuit had held that the Corps could not assert jurisdiction over wetlands that its own river maintenance activities had created. See United States v. City of Fort Pierre, 747 F.2d 464 (8th Cir. 1984). The Seventh Circuit had expressed misgivings about the assertion of jurisdiction over an "isolated" wetland in Hoffman Group, Inc. v. EPA, 961 F.2d 1310, 1321-23 (7th Cir. 1992). EPA's administrative penalty order was later set aside in that case for a lack of evidence connecting the site to navigable waters in Hoffman Homes, Inc. v. EPA, 999 F.2d 256 ( 7 th Cir. 1993). That court also rejected the use of groundwater to link an artificial pond to navigable waters. See Village of Oconomowoc Lake v. Dayton Hudson Corp., 24 F.3d 962, $965-$ 66 (7th Cir. 1994). And in United States v. Wilson, 133 F.3d 251 (4th Cir. 1997), the Fourth Circuit rejected the extension of jurisdiction to waters that "could affect interstate commerce" as inconsistent with United States v. Lopez, 514 U.S. 549 (1995). See id. at 257 (sctting aside 33 C.F.R. $\S 328.3(\mathrm{a})(3)$ (1993) (emphasis in original)).

385. 531 U.S. 159 (2001). The Solid Waste Court distinguished "isolated" waters from the "adjacent" wetlands of Riverside by the latter's supposed "significant ncxus" to Lake St. Claire. See id. at 167-68.

386. 547 U.S. 715 (2006).

387. See Solid Waste Agency, 531 U.S. at 167-74 (concluding that, for the Act to reach such "waters," Congress would have to have made a clear statement of its intentions to that effect given the overlapping state and local government authority to regulate such areas).

388. Cf. Rapanos, 547 U.S. at $810 \&$ n.14 (Stevens, J., dissenting) (noting that a concurrence by Justice Kennedy supporting CWA jurisdiction over any target areas bearing a "significant nex- 
ed the agencies for failing to clarify their interpretations. ${ }^{390}$ But this internecine struggle left a jurisdictional mess to the lower courts. ${ }^{391}$ A year later, the agencies published guidance for their field offices. ${ }^{392}$ To the agencies, non-navigable tributaries of "traditional navigable waters,"393 together with wetlands having provable connections to such tributaries, were jurisdictional-at least where the connections were relatively constant and robust. ${ }^{394}$ Yet the jurisdictional troubles kept deepening as gradient indeterminacy combined with the vagaries of evidence gathering and other variabilities in the field. ${ }^{395}$ Enforcement actions became polarizing jurisdictional battles, one permutation of tributary, wetland, or degree of connectivity at a time. ${ }^{396}$

us" to navigable waters had only his votc and should be interpreted by lower courts, in tandem with the dissenters' deference to the agencics, as supporting jurisdiction anywhere the plurality's requirements were met or where the nexus test was met).

389. ESTREICHER \& SEXTON, supra note 216 , at 95 . Whatever the merits of the Court's taking a "maximalist" approach in its opinions, compare Grove, supra note 101, (defending "vertical maximalism" to promote clarity and settlement in federal law), its demonstrated inability to do so with jurisdiction over counsels pursuing other solutions. See infra Part V.

390. See Rapanos, 547 U.S. at 757-58 (Roberts, C.J., concurring).

391. See Colburn, supra note 39 , at 88-90.

392. See U.S. EPA \& U.S. Dept. of the Army, Clcan Water Jurisdiction Following the U.S. Supreme Court's Decision in Rapanos v. United States \& Carabell v. United States (June 5, 2007) (hercafter "2007 Guidance") (copy on filc with author). Bcsides the categorical inclusion of "traditional" navigable waters and interstate waters, the agencies also signaled in a "summary of key points" that they "generally" would not assert jurisdiction over "swales or erosional features," or "[d]itches (including roadside ditches) excavated wholly in and draining only uplands and that do not carry a relatively permanent flow of water ...." Id. at 1 . By the time this 2007 Guidance was published, a lower federal court had already held that Rapanos supported reaching non-navigable tributarics and adjacent wetlands bearing a "significant nexus" to navigable and interstate waters. See United States v. Gerke Excavating, 464 F.3d 723, 724-25 (7th Cir. 2006).

393. "Traditional navigable waters" were waters currently, historically, or susceptible to being used "in interstate or forcign commerce, including all waters which are subject to the ebb and flow of the tide." 2007 Guidance, supra note 392 , at 4 .

394. See 2007 Guidance, supra note 392 , at 5 .

395. EPA was again faulted in 2008 for not adapting its jurisdictional practices to Solid Waste and Rapanos. See Amer. Petro. Inst. v. Johnson, 541 F. Supp. 2d 165, 178-85 (D.D.C. 2008). Yet opinions in the courts of appeal soon turned toward the Rapanos dissenters' view that $\S 502(7)$ extcnded to any water matching either the plurality's or Justice Kenncdy's interpretation. See United States v. Donovan, 661 F.3d 174, 180-81 (3d Cir. 2011) (collecting cases)). By 2018, "[a]ll circuit courts that ha[d] ruled on the matter ha[d] concluded that an area meeting Justice Kennedy's significant nexus test is within CWA jurisdiction, although some circuit courts ha[d] decided that jurisdiction applies if the area meets either the significant nexus test or the plurality's 'relatively permanent' test." J.B. Ruhl, Proving the Rapanos Significant Nexus, 33(1) NAT. RES. \& ENVT. 51, 52 (Summer 2018).

396. See, e.g., United States v. Johnson, 467 F.3d 56 (1st Cir. 2006); United States v. Moses, 496 F.3d 984 (9th Cir. 2007); United States v. Robison, 505 F.3d 1208 (11th Cir. 2007); United States v. Cundiff, 555 F.3d 200 (6th Cir. 2009); United States v. Brink, 795 F. Supp.2d 565 (S.D. Tex. 2011); United States v. Vierstra, 803 F. Supp.2d 1166 (D. Idaho 2011); United States v. 


\section{B. Judicial Choice: Facts, Fictions, and Article III}

By 2015 , groundwater, canals, and transfers relocating tributary flow had all joined wetlands and non-navigable tributaries at $\S 502(7)$ 's contentious frontier. ${ }^{397}$ But the guidance 398 was to be replaced by a "Clean Water Rule" (CWR). ${ }^{399}$ And EPA's vast literature review synthesizing some 1,200 peer-reviewed articles on the connectivity of streams and wetlands to downstream waters aimed directly at the Court's Rapanos and Solid Waste opinions. ${ }^{400}$ Federalist fears of creeping centraliza$\operatorname{tion}^{401}$ were answered with domain expertise, the agencies' case for rulemaking over case-by-case adjudications, and the fact that the CWA delegation had fractured the Court in Rapanos.

In a methodical and exhaustive Connectivity Report, EPA found that "[w]aters are connected in myriad ways, including physical connections and the hydrologic cycle; however, connections occur on a continuum ... from highly connected to highly isolated. ${ }^{.402}$ It identified five

Hamilton, 952 F. Supp.2d 1271 (D. Wyo. 2013); United States v. Smith, 303 F.R.D. 630 (S.D. Ala. 2014).

397. See Catskill Mtns. Chap. Trout Ultd., Inc. v. EPA, 8 F. Supp. 3d 500, 506-17 (S.D.N.Y. 2014) (reviewing regulatory and litigation history of water transfers), rev' $d$ Catskill Mtns. Chap. Trout Ultd., Inc. v. EPA, 846 F.3d 492 (2d Cir. 2017); Los Angeles Cty. Flood Control Dist. v. Natural Resources Defense Council, Inc., 133 S. Ct. 710, 711 -13 (2013) (reviewing litigation history of engineered tributaries); Decker v. Nw. Envtl. Defense Ctr., 133 S. Ct. 1326, 1331-34 (2013) (reviewing litigation and guidance history of stormwater runoff discharges); Hawai'i Wildlife Fund v. County of Maui, 24 F. Supp.3d 980, 992-98 (D. Haw. 2014) (describing litigation history of groundwater), aff $d$, Hawai'i Wildlife Fund v. Cty. of Maui, 886 F.3d 737 (9th Cir. 2018). Each of the most controversial boundaries were addressed by either the Clean Water Rule or other rulcmakings. See Clean Water Rulc, 80 Fed. Reg. at 37075-80 (tributaries and ditches); id. at 37099-100 (groundwater); U.S. EPA, Final Rulc-National Pollutant Discharge Elimination System (NPDES) Water Transfers Rule, 73 Fed. Reg. at 33697 (2008) (exempting water transfers' conduits, canals, and other convcyances from definition of "point source").

398. See Richard E. Glaze, Jr., Rapanos Guidance III: "Waters" Revisited, 42 ENVTL. L. RPTR. 10118 (2012). Guidance occupics an uneasy middle ground between "legislative" rules that bind the public, the agency, and the courts and policy statements that bind no one. See Peter L. Strauss, The Rulemaking Continuum, 41 DUKE L.J. 1463, 1475-87 (1992).

399. See U.S. Dept. of Defense, U.S. EPA, Final Rule-Clean Water Rule: Definition of "Waters of the United States," 80 Fed. Reg. 37054 (2015).

400. See U.S. EPA, CONNECTIVITY OF STREAMS \& WETLANDS TO DOWNSTREAM WATERS: A REVIEW \& SYNTHESIS OF THE SCIENTIFIC EVIDENCE EPA/600/R-14/475F (2015) [hereinafter CONNECTIVITY REPORT]; Colburn, supra note 39, at 105-15.

401. In both cases, the constitutionality of reaching attenuated areas was put in doubt. $C f$. Solid Waste Agency of N. Cook Cty. v. U.S. Army Corps of Eng'rs, 531 U.S. 159, 172 (2001) ("Where an administrative interpretation of a statute invokes the outer limits of Congress' power, we expect a clear indication that Congress intended that result."); Rapanos v. United States, 547 U.S. 715, 738 (2006) ("[T]he Corps' interpretation stretches the outer limits of Congress's commerce power and raises difficult questions about the ultimate scope of that power."). 402. See 80 Fed. Reg. at 37057 ; see also CONNECTIVITY REPORT, supra note 400 , at $\$ 2.4$. 
distinct mechanisms of functional connectivity in detail: materials sourcing and sinking (transport); refuge; transformation of biological, chemical, and physical constituents; and time-lagging. ${ }^{403}$ It documented how connectivity varies over space and time-variability that can be measured in frequency, duration, magnitude, sequence, and rapidity. ${ }^{404}$ And it noted humanity's constant interference with and alterations of that connectivity. ${ }^{405}$

Yet these findings came backing a rulemaking that was neither required nor sanctioned by the Act. ${ }^{406}$ They were finalized without any adversarial testing. ${ }^{407}$ And they cast $\S 502(7)$ 's true geographic scope as a fundamental challenge to our jurisdiction-splitting ways. The agencies signaled clearly their intent that the rule be "legislative," changing wa-

403. See CONNECTIVITY REPORT, supra note 400, at ES-6. The Report's five "major" conclusions trace the connectivity of streams, wetlands, and open waters by degree and by mechanisms falling somewhere along the gradient EPA described, finishing with the conclusion that "[d] ownstream waters are the time-integrated result of all waters contributing to them." Id. at ES5 .

404. See CONNECTIVITY REPORT, supra note 400, at 2-29. "Connectivity is not a fixed characteristic of a system, but varies over space and time ... [and] results primarily from the longitudinal and lateral cxpansion and contraction of the river network and transient conncction with other components of the river system." Id. (internal citations omitted).

405. Compare Matthew J. Cohen et al., Do Geographically Isolated Wetlands Influence Landscape Functions?, 113 PROC. AMER. ACAD. SCI. 1978, 1983 (2016) (detailing the dramatic influences human alterations of landscapes exert on the connectivity of wetlands and attenuated tributaries to downstream waters), with CONNECTIVITY REPORT, supra note 400, at 5-10 (concluding from a series of case-studies that the effects of human alterations depend on the water body type, are typically complex and that coupled human-natural systems are an arca of active research). An independent synthesis following the Connectivity Report confirmed its foundational methods, proof, and major conclusions. See Ken M. Fritz et al., Physical and Chemical Connectivity and Streams and Riparian Wetlands to Downstream Waters: A Synthesis, 54(2) J. AMER. WATER RES. ASS'N 323 (2018).

406. The Act's all-purpose authorization to EPA is "to prescribe such regulations as are necessary to carry out [its] functions" under the Act. 33 U.S.C. $\$ 1361$ (a). But this is independent of the CWA's special statutory revicw safe harbor for certain rules. In $\S 509(\mathrm{~b})(1)$, seven enumerated types of EPA actions are listed and shiclded from "judicial review in any civil or criminal proceeding for enforcement" if "review could have been obtained" thereunder at the time of the rulemaking. Id. at $\S 1369(\mathrm{~b})(2)$. Thus, in National Association of Manufacturers. $v$. Department of Defense, 138 S. Ct. 617 (2018), the Court held that general federal question jurisdiction in an appropriate district court was the proper forum for challenges to the CWR. Id. at 628-34.

407. Article III arguably requires some kind of judicial revicw when interests protected by the Constitution are adjudicated. See Richard H. Fallon, Jr., Of Legislative Courts, Administrative Agencies, and Article III, 101 HARV. L. REV. 915, 986-91 (1988) (discussing Crowell v. Benson, 285 U.S. 22, 60-61 (1932), and cases following it); Thomas W. Merrill, Article III, Agency Adjudication, and the Origins of the Appellate Review Model of Administrative Law, 111 COLUM. L. REV. 939 (2011) [hereinafter Merrill, Appellate Review Model] (linking the history of administrative procedure to the rise of deferential judicial review and the Chevron doctrine). 
ters' status categorically. ${ }^{408}$ (Hence the kinetic response. ${ }^{409}$ ) The rule attracted thousands of participants, considerable media attention, and several of Washington's most powerful lobbies in opposition. ${ }^{410}$ It even featured in the 2016 election in several states. ${ }^{411}$ And, as mentioned, the lawsuits challenging it swamped it immediately. ${ }^{412}$ The Trump Administration's effort to replace the 2015 rule $^{413}$ brings the Connectivity $R e$ port full circle - especially in the wake of the Supreme Court's holdings that both the Corps' and EPA's specific jurisdictional determinations are "final agency action" and immediately reviewable in federal district court. ${ }^{414}$

Administrative action like the Connectivity Report and its place in Article III proceedings have long divided courts and commentators. ${ }^{415}$ One question is whether an Article III court's "judicial Power" should or

408. Unlike other rules, so-called "legislative" rules can create, amend, or abolish legal interests. See Manning, supra note 345, at 914; Gersen, supra note 345, at 1708-13; Funk, supra note 345, at 659; Merrill \& Watts, supra note 345, at 470-74. But cf. Strauss, supra note 398 , at 1471-75 (noting the existence of a "tertium quid" between rules having and those lacking the force of law). The Court has regularly declared that legislative rules "have the force and cffect of law." See Perez v. Mrtg. Bankers Ass'n, 135 S. Ct. 1199, 1208 (2015). Although the Court has held that CWA $\S 301$ 's effluent limitations mandates delegated to EPA the power to make binding rules on the discharge of pollutants from point sources to jurisdictional waters, see E.I. DuPont de Nemours \& Co. v. Train, 430 U.S. 112 (1977), it has never resolved the question professors Merrill and Watts posed in 2001: whether the CWA's generic rulcmaking grant in $\$ 501$ (a) constitutes such a delegation. See Merrill \& Watts, supra note 345 , at 584 n.634.

409. See Claudia Copeland, Cong. Research Serv., EPA and the Army Corps' Rule to Define "Waters of the United States," at 10 (Jan. 4, 2016) (CRS R43455) (reporting agencies' intentions not to expand jurisdictional reach but surely to "increase the categorical assertion of CWA jurisdiction, when compared to a baseline of current practices under the 2003 and 2008 EPA-Corps guidance"). The CWR's several categorical exemptions drew environmentalist objections. See Patrick Parentcau, A Bright Line Mistake: How EPA Bungled the Clean Water Rule, 46 ENVTL. L. 379 (2016).

410. See Final Rule-Clean Water Rule: Definition of "Waters of the United States," 80 Fed. Reg. 37,054, 37,095 (2015) (describing "major comments"); Proposed Rule-Revised Definition of "Waters of the United States," 84 Fed. Reg. 4154, 4160-62 (2019) (reviewing litigation history surrounding 2015 rulemaking).

411. See, e.g., Tiffany Stecker, WOTUS 'Ultimately Doomed.' What Happens Next?, GREENWIRE (Nov. 16, 2016), available at https://www.cenews.net/stories/1060045861.

412. See supra notes $43-44$ and accompanying text.

413. See Proposed Rule, 84 Fed. Reg, at 4218-20.

414. See U.S. Army Corps of Eng'rs v. Hawkes Co., Inc., 136 S. Ct. 1807, 1813-15 (2016); Sackett v. EPA, 566 U.S. 120, 125-26 (2012).

415. See Fallon, Legislative Courts, supra note 407, at 933-49; Henry Paul Monaghan, Constitutional Fact Review, 85 CoLUM. L. REV. 229, 247-63 (1985); John Dickinson, Crowell v. Benson: Judicial Review of Administrative Determinations of Questions of "Constitutional Fact," 80 U. PA. L. REV. 1055 (1932). Jurisdictional facts turn factual into normative disputes and therefore pose complex questions about the appropriate standards of proof. See Kevin M. Clermont, Jurisdictional Fact, 91 CORNELL L. REV. 973 (2006). 
can be bound by someone else's fact-finding. ${ }^{416}$ But the better question is whether federal courts can afford to ignore domain expertise like it. For if the scientific consensus on connectivity described there poses so fundamental a challenge to our fictional divisions in waters governance, it is the fictions that should go. Through its fractious opinions on $\S 502(7)$ and on the CWA's special statutory review provisions, ${ }^{417}$ the Court has embodied the judiciary's incapacity to settle the Act's territorial scope - ceding to fact-driven litigation one tributary, ditch, and wetland at a time questions that only general norms can settle generally. ${ }_{418}$ Ironically, challenges to any final Trump rule must now begin in district court where the forum-shopping incentives loom largest, ${ }^{419}$ where scaling the relief awarded has become a quagmire, ${ }^{420}$ amid procedural mismatches between the Federal Rules and petitions for review, ${ }^{421}$ and where the operation of the Court's vague "ripeness" and finality doctrines will invite still more disparity and forum-shopping. ${ }^{422}$ To attribute this jurisdictional swamp to Congress is to disparage the work of a coequal branch. ${ }^{423}$

\section{PATHS FORWARD}

Whether horizontal, ${ }^{424}$ vertical, ${ }^{425}$ or diagonal, ${ }^{426}$ jurisdiction split-

416. Cf. KenNeth Culp Davis, 2 Administrative Law Treatise $\S 16.08$ (1958) (describing a domain of "jurisdictional facts" which, if found by an administrative agency, merit spccial scrutiny from a revicwing court).

417. Compare Harrison v. PPG Indus., Inc., 446 U.S. 578, 593 (1980) (construing the Clean Air Act to consolidate review in a single court of appcals for its time-saving advantages over dispersed review in district courts), with Crown Simpson Pulp Co. v. Costle, 445 U.S. 193 (1980) (construing CWA $\S 509(\mathrm{~b})(1)$ to allow appcals court review for same reasons).

418. Hawkes and Sackett cleared the path for burdened landowners' challenges to individual jurisdictional determinations in district court under $\S 1331$ and the APA. See Hawkes, $136 \mathrm{~S}$. Ct. at 1812; Sackett, 566 U.S. at 127-31. But neither involved a challenge to an agency "rule"-which presumably remain subject to the Court's notoriously opaque ripeness doctrines if brought in district court. See John F. Duffy, Administrative Common Law in Judicial Review, 77 TEX. L. REV. $113,162-78$ (1998).

419. See Samuel L. Bray, Multiple Chancellors: Reforming the National Injunction, 131 HARV. L. REV. 417, 457-61 (2017); Joseph W. Mead \& Nicholas A. Fromherz, Choosing a Court to Review the Executive, 67 ADMIN. L. REV. 1, 28-30 (2015).

420. See Bray, supra note 419 , at $437-45$.

421. See Mead \& Fromherz, supra note 419, at 28-30.

422. See Daniel Boger, Pre-Enforcement Review: An Evaluation from the Perspective of Ripeness, 36 VA. ENVTL. L.J. 77, 103-06 (2018).

423. Cf. NOURSE, supra note 354 , at 101 ("Federal judges-who have no constituencyhave a duty to respect legitimate policy choices made by those who do.") (quoting Chevron, 467 U.S. at 866).

424. Examples of horizontal jurisdiction splitting described above include the CWA $\S 502(7)$ "waters" delegation to the federal courts and/or agencies; the basin adjudications of 
ting has been acutely problematic in our water conflicts. Yet still it proliferates. It consigns compelling claims for relief to adjudication by rules of decision that are neither fixed nor forum-relative, accumulating over time into tangles of unintelligible complexity. With dueling federal and state sovereign and proprietary interests in most waters, whatever private rights of use may vest are specially limited not just by rival claimants but by multiple ranks of competing public claims as well. ${ }^{427}$ By constraining what any claimant can hope to call theirs, even a more elaborate, robust test for constitutional property "denominators" 428 is not going to provide much security against divestment or loss. ${ }^{429}$ Paradoxically, this undermines the best reasons for vesting private entitlements in the first place ${ }^{430}$ while generating considerable frictions that lock-in legacy arrangements all the same. ${ }^{431}$

Concurrent jurisdiction to manage the jealousies and fears our federalism engenders began simply enough. ${ }^{432}$ But dividing popular sovereignty over waters has proven far more complicated than the Founders appreciated. ${ }^{433}$ Disentangling interrelated, often competing interests

tributaries and aquifers underlying any larger system; and the overlapping powers of Congress and the Supreme Court to resolve interstate conflicts over shared waters.

425. Examples of vertical jurisdiction splitting described above include the Colorado River and McCarran Amendment placement of federal common law rights in state courts, e.g., the Big Horn litigation; exclusive use of the certiorari jurisdiction to reform any federal reclamation law misconstrued in basin adjudications; and the adjudication of interstate waters' equitable apportionment in the Supreme Court without authority to apportion intrastate uses or related tributaries or groundwater.

426. The diagonal jurisdiction splitting described above was the Federal Circuit's certification of the "vested beneficial interest" claim to the Oregon courts and its eventual remand to the U.S. Court of Fcderal Claims.

427. See supra notes $84-142$ and accompanying text.

428. See supra notes $250-56$ and accompanying text.

429. See supra notes 323-37 and accompanying text. This may explain why so many reclamation water users pursue contractual remedies alone. See Benson, supra note 34, at 397-401.

430. See Bray, supra note 209, at 1309-14 (explaining how "clouded ownership" reduces values overall, not just those of the most likely owner).

431. See supra notes 329-34 and accompanying text.

432. See, e.g., Missouri v. Illinois, 180 U.S. 208, 240-41 (1900) (taking original jurisdiction of interstate water pollution claim in part because "it must surely be conceded that, if the health and comfort of the inhabitants of a state are threatened, the state is the proper party to represent and defend them").

433. Popular sovereignty has long been tested by its territoriality. See RICHARD TUCK, THE SLEEPING SOVEREIGN: THE INVENTION OF MODERN DEMOCRACY 221-24 (2015); LACROIX, supra note 101, at 218-21; EDMUND S. MORGAN, INVENTING THE PEOPLE: THE RISE OF POPULAR SOVEREIGNTY IN ENGLAND AND AMERICA 267-87 (1988). And major river systems were the original theatre of dispute. See BENTON, supra note 346, at 43-59. As but one strategy to manage "legal difference," however, extraterritoriality has expanded tremendously since the founding. See Kal Raustiala, Does THE CONSTitution Follow the Flag? The Evolution of TERRITORIALITY IN AMERICAN LAW 21 (2009). 
amidst all the jurisdiction splitting has grown increasingly costly and decreasingly effectual in resolving much about the rights, duties, powers, privileges, and immunities in waters law. Yet the impasses traced here hardened over decades. From the Supreme Court's equitable apportionment docket to Erie's federal common law revolution to McCarran's dubious constructions in Colorado River and San Carlos to the conditions on a federal takings forum for reclamation project water, and finally to the courts' hostility toward a watershed-oriented CWA, emerges a common cause: a faith-whatever the facts-in the health of dividing authority to declare the law. ${ }^{434} \mathrm{~A}$ waters-focused jurisdictional policy would target that pathology for treatment over time. ${ }^{435}$ A detailed account must await future work, but this part sketches three distinct reform pathways.

\section{A. Righting Waters Adjudications}

When the Supreme Court found within the McCarran Amendment a federal policy of avoiding piecemeal litigation, ${ }^{436}$ it knew too little. ${ }^{437}$ In hindsight, general stream adjudications (GSAs) are rarely conclusive. Tribal and other federal claims to shared waters have lingered unresolved while the capacities of the federal courts to alleviate any of the resultant losses lay dormant on the theory that piecemeal resolution would be worse. ${ }^{438}$ But piecemeal resolution of the law in a watershedgiven its diversity and variability - is the only resolution possible. Much of the money and time spent on the GSAs has been in fear of what federal reservations or some eventual equitable apportionment might mean to a state's appropriators. ${ }^{439}$ It is now clear that the Court studiously avoids decreeing interstate apportionments ${ }^{440}$ and that reserved rights

434. Cf. DAHL, supra note 11 , at 145-51 (finding that frequent turnover in electoral majorities and broad consensus on basic values explains America's protection of minority interests more than Madison's “institutionalism").

435. Incremental solutions offer the benefits of experimentation. But of. Rubin \& Feeley, supra note 50, at 908-09 (arguing that, because "our political culture is essentially healthy," there is no "policy reason" that federal administrative subdivisions should not replace semi-autonomous states).

436. See supra notes 153-54 and accompanying text.

437. The Supreme Court's own jurisprudence may have been the principal reason the general stream adjudications expanded to the unmanageable proportions they assumed. See Pacheco, supra note 134, at 632-35.

438. See supra notes 161-64 and accompanying text.

439. See supra notes $166-70$ and accompanying text.

440. In the nine river basins it has adjudicated, the Court has entered a decree equitably apportioning flow to affected states only three times. See Nebraska v. Wyoming, 325 U.S. 589 
are usually the least of an irrigator's worries. ${ }^{441}$

Some have suggested repealing McCarran. ${ }^{442}$ But GSAs are increasingly self-limiting endeavors. Rarely do they merit the costs or delays entailed and most are winding down. ${ }^{443}$ If anything, growing scarcities and improving knowledge of river systems are likely to bring GSA judgments into conflict with one another. ${ }^{444}$ Going forward, if the Supreme Court were to narrow Colorado River and San Carlos, ${ }^{445}$ recognizing that a waiver of immunity from suit in state court vests no authority in federal courts to refuse jurisdiction granted them, ${ }^{446}$ the Declaratory Judgment $\mathrm{Act}^{447}$ might serve as a useful tool for broken stream regimes that have interwoven so many claim types. ${ }^{448}$ Federal common law, from which so many of our waters' ordering principles stem, has been deeply problematic in state court. ${ }^{449}$ Federal declaratory actions can at least avoid the reverse-Erie traps and the prickly manage-

(1945); New Jerscy v. New York, 283 U.S. 336 (1931); Wyoming v. Colorado, 259 U.S. 419 (1922).

441. See Bryan, supra note 142, 507-16; ENVTL. LAW INST., supra note 357, at 24-28; MacDonnell, supra note 63, at 229-42.

442. See, e.g., Huber \& Zellmer, supra note 126, at 289-91; MacDonnell, supra note 63, at 342-45; Pacheco, supra note 134, at 669; McElroy \& Davis, supra note 18, at 648.

443. See Feller, supra note 131, 439-40; Thorson et al., Dividing Western Waters II, supra note 18 , at $47-63$.

444. See supra notes 207-11 and accompanying text.

445. Colorado River and San Carlos Apache are more easily narrowed than overrulcd. See Re, Supreme Court, supra note 187, at 1865 (" $[\mathrm{N}]$ arrowing happens all the time, with the approval of every recent Supreme Court Justice. Indeed, cases are narrowed far more frequently than they are overruled, as the Court routinely encounters scenarios in which a past decision is worth pruning but not abolishing.").

446. See Quackenbush v. Allstate Ins. Co., 517 U.S. 706, 716-20 (1996) (stating that federal courts may abstain when they possess discretion to grant or withhold relief, including in the declaratory judgment context, but that for actions "at law" this will typically only be authority to delay, not to dismiss, a suit); Shapiro, supra note 165, at 579-80; see also Lexmark Int'l v. Static Control Comps., Inc., 572 U.S. 118, 128-30 (2014) (holding that courts may not limit causes of action Congress has created merely out of judicial "prudence").

447. 28 U.S.C. $\S \S 2201-02$. As an "anticipatory" remedy, a federal declaratory judgment may issue only to resolve "a substantial controversy, between parties having adverse legal interests, of sufficient immediacy and reality to warrant the issuarice of a declaratory judgment." Medimmune, Inc. v. Genentech, Inc., 549 U.S. 118, 127 (2007).

448. The Court in Colorado River and San Carlos repeatedly emphasized that the state adjudication must provide an adequate forum for every federal issue. See Arizona v. San Carlos Apache Tribe, 463 U.S. 545, 559-60 (1983); Colo. River Water Con. Dist. v. United States, 424 U.S. $800,812,820$ (1976). Where adequate attention is not promised to all federal claims, abstention is inappropriate. See, e.g., Moses H. Cone Mem. Hosp. v. Mcrcury Constr. Corp., 460 U.S. 1, 26-27 (1983).

449. See supra notes $175-80$ and accompanying text. 
rial work of equitable decrees. ${ }^{450}$ It might even be a vehicle for western water law's waste and forfeiture doctrines finally to drive real innovations for distressed systems. ${ }^{451}$

Perhaps most importantly, a federal court can resolve claims on systems not confined to any single state. ${ }^{452}$ And because a federal forum's abstention is only preferable where the law is better fit to a state forum, ${ }^{453}$ federal common law claims or defenses (or the inchoate sovereign interests from which they arise) and interstate boundaries should make it relatively rare. Indeed, as water rights litigation has matured, sovereign interests have constantly evolved and influenced water law and this intersection can only be settled, fully and fairly, in context. ${ }^{454}$ Finally, federal courts' jurisdiction over nonresident defendants, although generally limited by federal statute and rule to the jurisdiction of their state, ${ }^{455}$ may need to protect the interests that state forums cannot. ${ }^{456}$ As the Supreme Court's equitable apportionment practice has

450. Cf. Steffel v. Thompson, 415 U.S. 452, 467-71 (1974) (calling the declaratory judgment "milder" than the injunction because it does not directly constrain the loser); RESTATEMENT (2D) OF JUDGMENTS $\S 33 \mathrm{cmt}$. c (1982) ("A declaratory action is intended to provide a remedy that is simpler and less harsh than cocreive relicf, if it appears that a declaration might terminate the potential controversy.").

451. Cf. Bray, supra note 209, at 1309-14 (arguing that cases of clouded ownership are often uniquely suited to declaratory judgment); Shupe, supra note 69, at 501-11 (tracking how actions targeting waste would encourage innovations in usage).

452. See, e.g., Brooks v. Unitcd States, 119 F.2d 636 (9th Cir. 1941); United States v. Alpine Land \& Res. Co., 503 F. Supp. 877 (D. Nev. 1980), rev'd on other grounds, Nevada v. United States, 463 U.S. 110 (1983); United States v. Walker River Irr. Dist., 11 F. Supp. 158 (D. Nev. 1935), rev'd on other grounds, 104 F.2d 334 (9th Cir. 1939). Several federal court judgments, at lcast one of which was affirmed by the Supreme Court, enjoin (non-forum) upstream state diversions in favor of a resident user in a downstream state. See Brooks, 119 F.2d at 639-43 (upholding contempt sanctions against out-of-state, out-of-priority users); Vineyard Land \& Stock Co. v. Twin Falls Salmon River Land \& Water Co., 254 F. 9, 26-28 (9th Cir. 1917); Rickey Land \& Cattle Co. v. Miller \& Lux, 152 F. 11 (9th Cir. 1907), aff'd, 218 U.S. 258 (1910); New Liverpool Salt Co. v. Calif. Dev. Co., 172 F. 792 (9th Cir. 1909). The Tenth Circuit refuscd to do so in AlbionIdaho Land Co. v. Naf Irr. Co. 97 F.2d 439, 444 (10th Cir. 1938).

453. See supra notcs 156-62 and accompanying text.

454. See supra note 209 and accompanying text.

455. Federal Rule of Civil Procedure 4 limits the territorial jurisdiction of a district court (cssentially) to that of the state in which it sits, see FED. R. CIV. P. 4(k)(1)(A), although not completely. See id. $4(\mathrm{k})(1)(\mathrm{B})$ (allowing summons on persons who are Rule 14 or Rule 19 parties to be summoned if located within 100 miles of the summoning court's district). This, too, traces to the Judiciary Act of 1789. See Robertson v. R.R. Labor Bd., 268 U.S. 619, 623 (1925) (citing Judiciary Act of 1789 , ch. $20, \S 11,1$ Stat. 73,79 ). Such restrictions could be loosened consistent with the Constitution. See Jamelle C. Sharpe, Beyond Borders: Disassembling the State-Based Model of Federal Forum Fairness, 30 CARDOzO L. REV. 2897 (2009); A. Benjamin Spencer, Nationwide Personal Jurisdiction for our Federal Courts, 87 DENV. U. L. REV. 325 (2009).

456. General federal interests are quite familiar. Cf. McConnell, supra note 10, at 14921500 (listing responsiveness to diverse interests and preferences, minimizing interstatc externali- 
shown, these interests have emerged faster than they have been adjudicated.

Although court judgments backing senior "calls" on upstream diversions are nominally limited to their issuing jurisdiction, ${ }^{457}$ Western waters will increasingly test this paradigm. ${ }^{458}$ Water rights are paradoxically intangible ${ }^{459}$ and intangible property is famous for challenging territorial jurisdiction. ${ }^{460}$ The situs of its use easily confounds ordinary theories of tort and territoriality. So, for example, diverted water (which is rarely fully "consumed" but is rather yielded back in large part) keeps use practices involving that water of acute and immediate interest to those downstream. ${ }^{461} \mathrm{~A}$ familiar dilemma is the cumulative effect of a jurisdiction's irrigators on a river's downstream character and extent, ${ }^{462}$ a conflict that, by crossing state lines, raises uniquely federal interests. ${ }^{463}$ A waters-focused jurisdictional policy would generally seek the highest coincidence of governing law, sovereign interests, and original jurisdiction - the better to enable timely and effective adjudication of multiple overlapping and competing interests. If more than one sovereign's interests or laws are implicated, that will typically count in favor of a federal forum, independent federal rules of decision, and/or an inclusive conflict-of-laws doctrine. ${ }^{464}$

tics, and the spurring of innovation through inter-jurisdictional competition). Sorting them in context can require policy-guided reconstructions of jurisdiction, procedure, and more. See, e.g., Illinois v. City of Milwaukce, 406 U.S. 91, 93-94 (1972) (holding that 28 U.S.C. $\$ 1251$ and Article IIl should be interpreted to restrict original jurisdiction docket to those cases that are "appropriate" and leaving original jurisdiction over all other cascs to district courts); Ohio v. Wyandotte Chems. Corp., 401 U.S. 493 (1971) (noting that the emergence of "long-arm" jurisdiction has obviated the need for original jurisdiction before the Supreme Court in all cases between a State and citizens of another state).

457. See Hinderlider v. La Plata River \& Cherry Creek Ditch Co., 304 U.S. 92, 103 (1938); Hill v. State, 894 N.W.2d 208, 215-19 (Neb. 2017).

458. See supra notes $284-86$ and accompanying text.

459. See supra notes 326-27 and accompanying text. Like money, water is fungible and, for many purposes, a fungible unit of account. See Fox, supra note 327, 24-25.

460. Cf. Stern, supra note 230, at 170-73 (noting that cash and commercial paper ordinarily follow a "situs" rule but that intellectual property need not do so because federal law ordinarily prevails and that in most other cases the location of the debtor is decisive); Fox, supra note 327 , at 318 (explaining that enforcement of title to incorporeal money may be sought in restitution).

461. See, e.g., Montana v. Wyoming, 563 U.S. 368, 378-80 (2011); cf. Squillace, supra note 326 , at 108,111-14 (proposing to define water rights in consumptive use terms because amounts diverted are a poor measure for purposes of transferability).

462. See ENVIRON. LAW INST., supra note 357, at 9-10 (discussing City of Thornton v. Bijou Irr. Co., 926 P.2d 1 (Colo. 1996)).

463. See, e.g., Arkansas v. Oklahoma, 503 U.S. 91, 98-102 (1992); Missouri v. Illinois, 180 U.S. 208, 240-41 (1901).

464. Cf. Monaghan, supra note 20 (arguing that federal supremacy has always included elements of law like administrative rules, precedents, and other tools nowhere mentioned in the Su- 


\section{B. Jurisdiction by Rule: Fixing the CWA}

Madison's signature mistake was in not anticipating the vacuums formed by so thoroughly constraining the Congress. ${ }^{465}$ The vacuums have pulled the courts, states, and agencies into updating the law and that has left delegative statutes like the CWA in jurisdictional knots. The Supreme Court's handling of CWA jurisdiction has introduced less "control"466 than outright chaos, illustrating just how wrong case-bycase approaches can go. ${ }^{467}$ Growing uncertainty in the administrative law of delegation, ${ }^{468}$ the CWA's ambiguous grants of authority even to make jurisdictional rules, and the Court's own opinions about $\S 502(7)$ and ripeness and finality, ${ }^{469}$ have reared a jurisdictional mess.

The Act's geographic scope now leaves affected parties to risky decisions, keeps state programs and watershed initiatives perpetually uncertain of their authority and consigns water users to an increasingly conflictual future. ${ }^{470}$ This is a legacy of adjudications exacerbating uncertainties where enacted textual rules could improve matters considerably. ${ }^{471}$ Furthermore, we surely do Article III no credit by refusing to update proof burdens that waste judicial resources through the repetitive litigation of general knowledge. ${ }^{472}$ And for all the rhetoric, courts and agencies have long adapted their roles cooperatively in jointly furthering Congress's expressed purposes. ${ }^{473}$ The Court has held, for example, that it will not accept EPA's sham refusals to act in the face of overwhelm-

premacy Clause that have proven vital to founding and sustaining a nation); Roosevelt, supra note 89, at 10-15 (describing a "two-step model" where a court first identifies the sovereigns that might attach legal consequences to the cvents and which have in fact done so to create a conflict and, secondly, to decide which of the competing rights, duties, powers, privileges, or immunities will be given priority); Wolff, supra note 132, at 1884-88 (explaining that Roosevelt's two-step approach to conflicts coincided with the rise of a constitutional doctrine of sovereign interests and fairness).

465. See McConnell, supra note 10, at 1502.

466. Retaining power over the finding of facts was a key part of the orthodox case for judicial control of the administrative state. See LOUIS L. JAFFE, JUDICLAL CONTROL OF ADMINISTRATIVE ACTION 624-53 (1965); see also Merrill, supra note 407, at 979-97.

467. See supra notes 368-96 and accompanying text.

468. See Elliott, supra note 344.

469. See supra notes 417-23 and accompanying text.

470. See Colburn, supra note 357.

471. See Colburn, supra note 39. For cxample, the Court, Congress, and most everyone clse eventually agreed that codified rules of civil procedure were better for efficiency, fairness, and transparency-notwithstanding considerable scparation of powers questions. See FALLON ET AL., supra note 8 , at 564-75.

472. See supra notes $415-18$ and accompanying text.

473. See Dickinson, supra notc 415, at 1074-77; Fallon, supra note 407, at 986-91; Pfander, supra note 8 , at 743-47. 
ing evidence supporting a finding of jurisdiction to regulate. ${ }^{474}$

In theory, Congress could fix the turmoil described in Part IV. But nothing is keeping Article III courts from taking seriously the general knowledge that watersheds, wetlands, and tributaries are intimately connected to downstream waters and that variance in that connectivity is not evidence of its absence. ${ }^{475}$ Even without a statutory fix for the CWA's rulemaking provisions, ${ }^{476}$ especially in the short term, this could mean real reform incrementally by better aligning the fact-finding to be done in court with what domain experts have said is well-known about watersheds. ${ }^{477}$

\section{Righting Reclamation Interests}

Reclamation Act $\S 8$ is in its second century of minting jurisdictional unicorns like "vested beneficial interests" out of the thin air of state law and judgments without associated recognition doctrines. ${ }^{478}$ Any field of law where federal supremacy is reserved specially for "direct Congressional directives" ${ }^{479}$ may be destined for troubles. ${ }^{480}$ But reclamation project disputes are growing more frequent and dire. ${ }^{481}$ Readying irrigation for increasing scarcity while minimizing the collateral damage is our challenge. In principle, use changes should be simpler with interests more transparently packaged and transferrable. ${ }^{482}$ However, federal taxpayers' interests in developed water and its infrastructure must be ap-

474. See Massachusetts v. EPA, 549 U.S. 497, 527-32 (2007); cf. Jody Freeman \& Adrian Vermeule, Massachusetts v. EPA: From Politics to Expertise, 2007 SUP. CT. REV. 51,52 (calling Massachusetts "expertise-forcing").

475. But see Orchard Hill Bldg. Co. v. U.S. Army Corps of Eng'rs, 893 F.3d 1017, 1025-26 (7th Cir. 2018) (holding that Corps had not amassed "substantial evidence" of target wetland's "significant nexus" to river because more than 160 other wetlands in watershed were not proven to be "similarly situated").

476. Express authority to make binding jurisdictional rules whilc consolidating review of those rules in a single circuit, as the CAA does with the D.C. Circuit, would surely increase the resolution of the ensuing norms. See Mead \& Fromherz, supra note 419, at 32-33.

477. See supra notes $402-05$ and accompanying text. The Court has perhaps inadvertently confirmed that the doctrinal tests for reviewable agency action applied in Bennett v. Spear, 520 U.S. 154, 178 (1997), and Sackett v. EPA, 566 U.S. 120, 128-31 (2012), present considerable equitable discretion. See Lindsay, supra notc 46, at 2473 \& n.179 (discussing U.S. Army Corps of Eng'rs v. Hawkes, $136 \mathrm{~S}$. Ct. $1807(2016)$ ). Timing any reviews of agency policy choices about $\S 502(7)$ 's scope, thus, should include attention to the systemic troubles described in Part IV.

478. See supra notes $284-98$ and accompanying text.

479. California v. United States, 438 U.S. 645, 670-71 (1978).

480. See supra note 275 and accompanying text.

481. See Kelley \& Benson, supra note $290, \S 41.05$.

482. See Squillace, supra note 326 , at 10811 ; Gould, supra note 68 , at 22-25. 
propriately valued and protected. ${ }^{483}$ Years of study suggest that these objectives are mutually exclusive in many projects, especially where interstate rivalries are afoot. ${ }^{484}$ Resolving disputes between states through first-in-time principles, though, arguably violates the losing state's equal sovereignty. ${ }^{485}$ Furthermore, investing the finality of a local action over real property in water rights judgments, though that finality may remain a "citadel" 486 to some, comports with little that we have learned about waters, watersheds, and situs jurisdiction overall. ${ }^{487}$

Congress last overhauled the Reclamation Act in $1982,{ }^{488}$ long before the troubles Part III traced came into view. ${ }^{489}$ The waiver of federal immunity for project water disputes remains narrow and technical. ${ }^{490}$ And the Act does nothing to prioritize uses-which a series of projectspecific statutes has also failed to do. ${ }^{491}$ Targeted but considerable jurisdictional reform could stem from courts' hearing claims of state law's preemption by the Act's residual concept of "beneficial use" as the "basis, measure, and limit" of project water deliveries. ${ }^{492}$ That residuum of

483. See Kcllcy \& Benson, supra note 290 , $\$ 41.07$.

484. See WATER TRANSFERS IN THE WEST, supra note 326 , at $27-30$ (noting lock-in effects, path dependence, and the necd to study successes in enhancing transferability as individual cascs).

485. See Patashnik, supra note 128, at 41-46; cf. OWEN, supra note 51, at 229-32 (noting that Utah's pending application to divert its allocated water in Colorado's upper basin is pressuring California and Arizona which have both long benefitted from Utah's forbearance).

486. Stern, supra notc 230 , at 115 (calling the situs rulc of adjudicating rights to property a "citadel ... of orthodoxy amid the rubble of the old order" that has since been replaced by more discriminating conflicts rules for everything but property). Federal court judgments may necessitate a federal preclusion rule. See Semtek Int'l, Inc. v. Lockhced Martin Corp., 531 U.S. 497, 509 (2001).

487. As the Restatement says, states generally have "power to exercise judicial jurisdiction to affect interests in an intangible thing ... if the relationship of the statc to the thing and to the parties involved makes excrcise of such jurisdiction reasonablc." RESTATEMENT (2D) OF CONFLICT OF LAWS $\S 65$ (1971). The presence of a diversion and/or of beneficial use within a state may provide an adequate basis for situs jurisdiction yet still be insufficient for exclusive jurisdiction. Cf. Hansberry v. Lee, 311 U.S. 32, 40 (1940) (holding that when a state court judgment's being given binding effect would amount to a denial of due process, it becomes the forum's duty to verify the constitutionality of the conflicts and preclusion rules applied).

488. See Pub. L. No. 97-293, 96 Stat. 1261 (1982), codified at 43 U.S.C. $§ \S 390 a a$ et seq.

489. See Benson, supra note 34 , at 395-97

490. See Orff v. United Statcs, 545 U.S. 596, 601-03 (2005) (holding that 43 U.S.C. $\S 390 u$ u is a waiver to join the United States as a "necessary" party in litigation between other parties to a reclamation contract dispute, not a waiver permitting suits against the United States directly or in general).

491. See Kelley \& Benson, supra note 290, at $\$ \S 41.07$ (b)-(c).

492. Reclamation Act $\S 8$ 's "bencficial use" may not be unique in its delegation of some federal authority to state law. See Jicarilla Apache Tribe v. United States, 657 F.2d 1126, 1133 (10th Cir. 1981) (looking to New Mexico's definition of "beneficial use"). But it must retain at least a residuum of federal content should the delivery be interstate, see Hinderlider v. La Plata River \& Cherry Creek Ditch Co., 304 U.S. 92, 102-03 (1938), or where a forum state lacks the 
federal "beneficial use" could combine with "Little Tucker" jurisdiction in federal district courts to hear any claims against the United States of up to $\$ 10,000$ (the threshold for CFC jurisdiction). ${ }^{493}$ Larger intermediaries with aggregate interests in project water might find this cold comfort. But it could provide an appropriate path to resolving the actual users' beneficial interests in project water that have so often evaded adjudication and clarification. ${ }^{494}$

Elaborating the above must await future work. It is well enough to have identified the forms of tyranny-by-inaction - invisible to Hobbes and Madison alike - now threatening our waters. The stakes are clear: more effort, time, and other resources devoted to jurisdictional strife mean less for actual governance and problem-solving. Left unchecked, they will continue to strain the nation's water security and aquatic resources. ${ }^{495}$ The underlying cause, replicated across waters disputes. of many kinds, has consisted foremost in courts' constant but subtle adaptation of the rules of decision, creating convoluted remedial pathways for injured parties even as the wider legal culture grows increasingly particularistic about the necessary bases of lawmaking authority. Congress may eventually decide that establishing dedicated federal tribunals possessed of sufficient original jurisdiction over water interests and water rights is the best way to overcome its own problems ${ }^{496}$ while addressing the problems highlighted here. Until that day, though, it will be incumbent upon courts, states, and agencies to begin curbing the pathological jurisdiction splitting our waters have suffered.

necessary basis for applying its law. Cf. Roosevelt, supra note 89, at 24-25 ("There are topics beyond the lawmaking power of the states... One such topic is the rights and obligations arising from events that have no connection to the forum state."). Changes of use in an upstream state harming users in a downstream state could present yet a third possibility necessitating either federal law or a neutral conflicts principle. "The range of judicial inventiveness" should be "determined by the nature of the problem." Textile Workers Union v. Lincoln Mills, 353 U.S. 448, 457 (1957).

493. See supra note 28.

494. The cases are legion where, because the United States was an indispensable party but immune from suit, dismissal of the suit ensued.

495. See Larson, supra note 13, at 159-64.

496. See NOURSE, supra note 354, at 25-26 (observing that Congress must speak to its constituencies, courts, agencies and others at the same time and must ordinarily act by supermajority). 
